San Jose State University

SJSU ScholarWorks

Master's Theses

Master's Theses and Graduate Research

Spring 2012

\title{
A Morphological Study of Eriogonum nortonii (Polygonaceae) and Implications for its Biogeography
}

Lisa Deree Morton

San Jose State University

Follow this and additional works at: https://scholarworks.sjsu.edu/etd_theses

\section{Recommended Citation}

Morton, Lisa Deree, "A Morphological Study of Eriogonum nortonii (Polygonaceae) and Implications for its Biogeography" (2012). Master's Theses. 4152.

DOI: https://doi.org/10.31979/etd.um4s-szgg

https://scholarworks.sjsu.edu/etd_theses/4152

This Thesis is brought to you for free and open access by the Master's Theses and Graduate Research at SJSU ScholarWorks. It has been accepted for inclusion in Master's Theses by an authorized administrator of SJSU ScholarWorks. For more information, please contact scholarworks@sjsu.edu. 


\title{
A MORPHOLOGICAL STUDY OF ERIOGONUM NORTONII \\ (POLYGONACEAE) AND IMPLICATIONS FOR ITS BIOGEOGRAPHY
}

\author{
A Thesis \\ Presented to \\ The Faculty of the Department of Biological Sciences \\ San José State University
}

\author{
In Partial Fulfillment \\ of the Requirements for the Degree \\ Master of Science
}

by

Lisa Deree Morton

May 2012 
(C) 2012

Lisa Deree Morton

ALL RIGHTS RESERVED 
The Designated Thesis Committee Approves the Thesis Titled

A MORPHOLOGICAL STUDY OF ERIOGONUM NORTONII (POLYGONACEAE) AND IMPLICATIONS FOR ITS BIOGEOGRAPHY

by

Lisa Deree Morton

APPROVED FOR THE DEPARTMENT OF BIOLOGICAL SCIENCES SAN JOSE STATE UNIVERSITY

May 2012

Dr. Susan Lambrecht

Dr. Rodney Myatt

Dr. John Matson
Department of Biological Sciences

Department of Biological Sciences

Department of Biological Sciences 


\begin{abstract}
A MORPHOLOGICAL STUDY OF ERIOGONUM NORTONII

(POLYGONACEAE) AND IMPLICATIONS FOR ITS BIOGEOGRAPHY

by Lisa Deree Morton
\end{abstract}

Morphological characters, phenology, and abiotic parameters were measured to determine whether divergence has occurred between populations of Eriogonum nortonii E. Greene on the east and west sides of the Salinas Valley. Morphological variability was demonstrated across all populations but not between populations on opposite sides of the valley. Investigations into present and paleoenvironmental factors as well as dispersal factors suggest recent episodes of long distance dispersal were responsible for the disjunct distribution of $E$. nortonii populations. 


\section{ACKNOWLEDGEMENTS}

I am indebted to the many people who were important in bringing this endeavor to fruition including Frank and Irene La Macchia of PL-Bar Ranch; Brent Johnson, Keir Morse, Daniel George, and Paul Johnson of Pinnacles National Monument; Patty Forbes and Jeff Gaffney of Hollister Hills SVRA; Tim Jenson and Rangers Al Miyamoto and Ray Trabucco of Monterey Peninsula Regional Park District; Deputy Chief Ranger Richard Higgins of the Monterey County Parks; and Mark Stromberg of Hastings Natural History Reservation.

Dr. George Thompson, professor emeritus of Stanford University, Emily Taylor of the USGS (Denver), and Diane Erwin of UCMP at Berkeley were giving of their time in answering my many questions on the geology of the northern Salinas Valley and paleofloral associations.

I am immensely grateful to many SJSU faculty, staff, and students who were so helpful to me including fellow students Suzy Woolhouse, Katherine Lai, and Xochilt Borja; the quick and reliable staff at MLK Library Illiad department; Drs. David Bruck, Nishanta Rajakaruna, and Chris Brinegar; Stephanie Trewhitt and Jennifer Cross of the Biology Department and Drs. Dave Anderson and Paula Messina of the Geology Department. Tim Andreis and Dr. Jeff Honda of the SJSU Biology Department gave a great deal of invaluable aid and advice on the molecular component of this project. I would never have been able to carry it out without their guidance and the use of Dr. Honda's lab space. I cannot say enough. Thank you so very much. I learned so much from you. 
It is an honor to have worked with my graduate and committee advisors Drs. Rod Myatt, Susan Lambrecht, and John Matson. Susan, thanks so much for the encouragement and for the stats help. I now have a newfound appreciation for statistics. Rod and Jack, though both officially retired, still stuck with me. I am deeply appreciative for that.

Friends and family have offered endless support and encouragement. My parents donated to the cause as well as provided their house as a nice escape. Danielle Tannourji most especially has been the best friend anyone could ask for, and the biggest thank you to my husband, David, for everything. Guess what? We can go diving now. 


\section{TABLE OF CONTENTS}

$\underline{\text { Section }}$

$\underline{\text { Page }}$

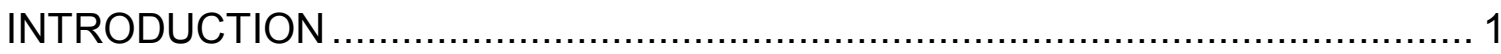

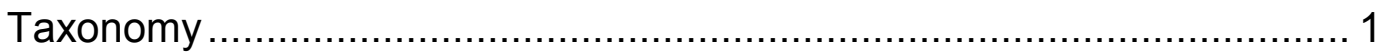

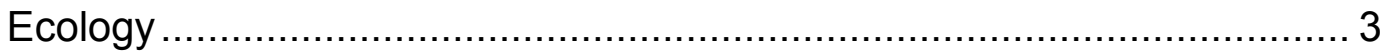

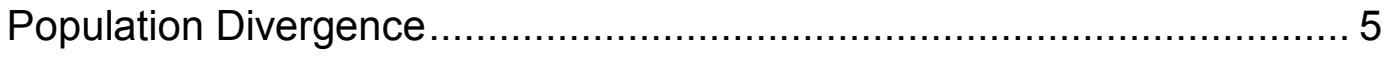

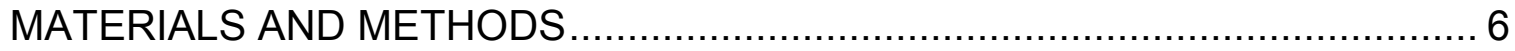

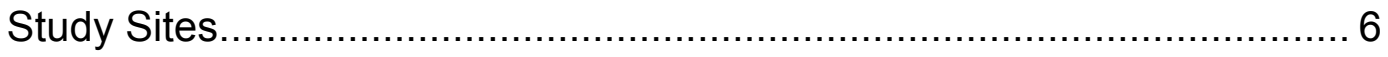

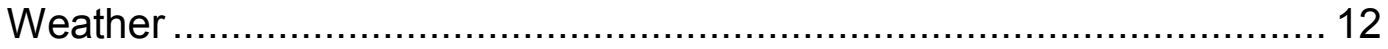

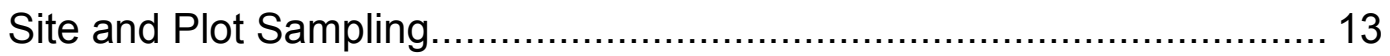

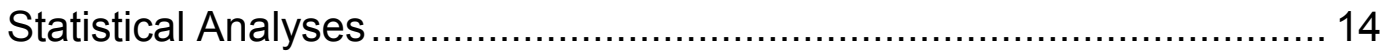

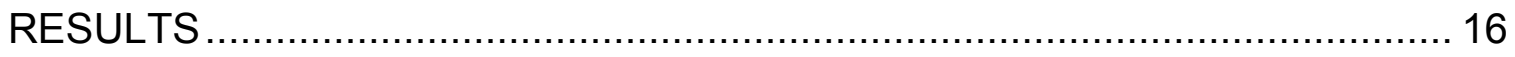

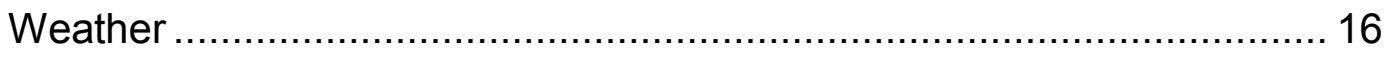

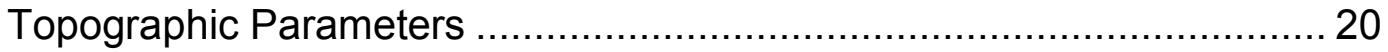

Morphological Characters …........................................................ 22

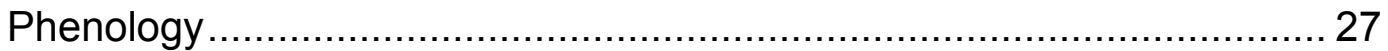

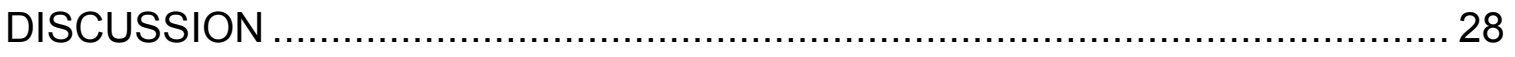

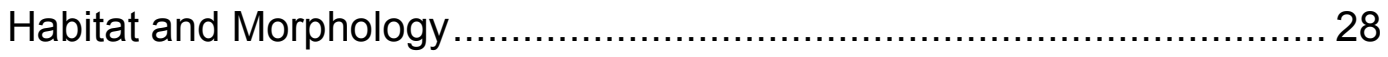

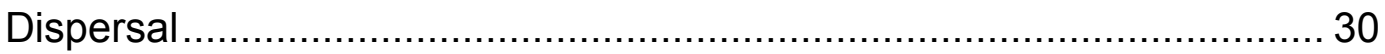

Diaspore Morphology and Dispersability ............................................. 31

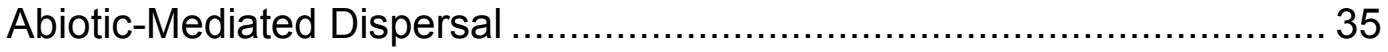

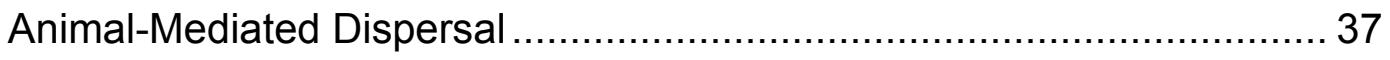




\section{TABLE OF CONTENTS}

$\underline{\text { Section }}$

$\underline{\text { Page }}$

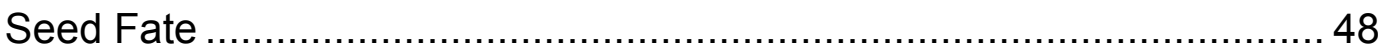

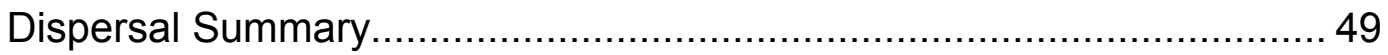

Paleoenvironment of Early Eriogonum Species.................................... 50

Salinas Valley and Central Coast Ranges Paleoenvironment ............... 52

Endemism and Biogeography of Eriogonum nortonii .......................... 67

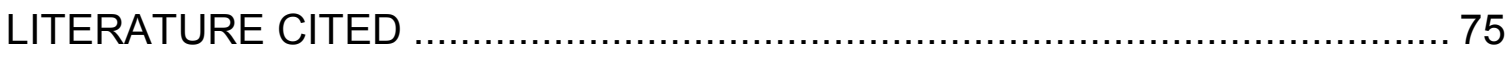




\section{LIST OF FIGURES}

Figure

$\underline{\text { Page }}$

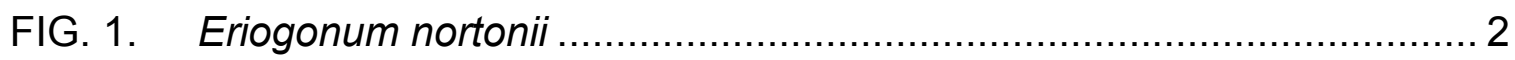

FIG. 2. Range of E. nortonii. Known populations (circle) ............................ 3

FIG. 3. Shrub interspaces in chaparral habitat at Pinnacles National Monument

FIG. 4. Study area in Monterey and San Benito Counties (inset) with 14 study sites (circle) and associated parent material ( $A, G, R, S) \ldots \ldots \ldots . .7$

FIG. 5. Gloria Valley and Pinnacles National Monument study sites ............... 9

FIG. 6. Climate stations (weather image) and study sites (circle)................ 13

FIG. 7. Nested GLM model incorporating four geographic levels within the distribution of $E$. nortonii

FIG. 8. Eight SRTM one-arc digital elevation datasets for the northern Salinas Valley region overlain by dominant wind vectors (arrow) for September 2007 to August 2008 and covering range of $E$. nortonii (circle).

FIG. 9. Drought coefficients from weather data across five climate stations for the September 2007 to August 2008 study period. 18

FIG. 10. Monthly averages of daily mean precipitation (cm/day), temperature $\left({ }^{\circ} \mathrm{C}\right)$, and relative humidity $(\%)$ for five climate stations from September 2007 to August 2008

FIG. 11. Elevation (m), aspect $\left({ }^{\circ}\right)$, and mean slope (\%; \pm SE) at $14 E$. nortonii study sites arranged from north to south and aggregated by orientation east or west of the Salinas Valley

FIG. 12. Average number of inflorescences ( \pm SE) per E. nortonii individual at 11 sites arranged from north to south and aggregated by orientation east or west of the Salinas Valley

FIG. 13. Average leaf width ( $\mathrm{mm} ; \pm \mathrm{SE}$ ) across $11 \mathrm{E}$. nortonii populations arranged from north to south and aggregated by orientation east or west of the Salinas Valley 


\section{LIST OF FIGURES}

Figure

$\underline{\text { Page }}$

FIG. 14. Mean plant height (mm; \pm SE) across 11 E. nortonii populations arranged from north to south and aggregated by orientation east or west of the Salinas Valley

FIG. 15. Relationship between average plant height $(\mathrm{mm})$ and aspect $\left(^{\circ}\right)$ across E. nortonii populations

FIG. 16. Percent inflorescences per plant in bud, flower, or mixed phenology across 13 populations aggregated by orientation east or west of the Salinas Valley. Sampling occurred 25 April 2008 to 30 May 2008

FIG. 17. Eriogonum nortonii achenes without perianth attached (upper circle) and with perianth attached (lower circle)

FIG. 18. Approximate Miocene restoration of northern Salinas Valley prior to dextral slip on the San Andreas and Rinconada faults

FIG. 19. Miocene macro and microfossil (*) paleoflora locations. Left figure represents present locations of paleofloras; right figure represents locations at time of deposition. Circled floras have shifted up to $315 \mathrm{~km}$ northwest along the San Andreas fault.

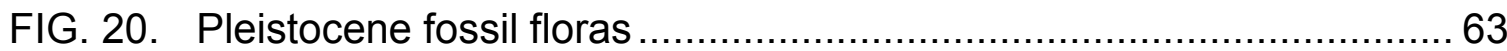




\section{LIST OF TABLES}

$\underline{\text { Table }}$

Page

TABLE 1. PARENT MATERIAL AND DOMINANT VEGETATION AT E.

NORTONII STUDY SITES.

TABLE 2. MEAN SLOPE (\%) COMPARISONS BETWEEN E. NORTONII STUDY SITES AGGREGATED BY ORIENTATION EAST AND WEST OF THE SALINAS VALLEY.

TABLE 3. MEAN LEAF WIDTH COMPARISONS BETWEEN E. NORTONII POPULATIONS AGGREGATED BY ORIENTATION EAST AND WEST OF THE SALINAS VALLEY ...... 24

TABLE 4. MEAN PLANT HEIGHT COMPARISONS BETWEEN E. NORTONII POPULATIONS AGGREGATED BY ORIENTATION EAST AND WEST OF THE SALINAS VALLEY ...... 26

TABLE 5. HARVESTER ANT SPECIES SIGHTED NEAR E. NORTONII SITES AT HASTINGS NATURAL HISTORY RESERVATION AND TORO COUNTY PARK INCLUDING FORAGING STRATEGY AND SEED RELIANCE

TABLE 6. GRANIVOROUS RODENT ABUNDANCE AT HASTINGS NATURAL HISTORY RESERVATION AND PINNACLES NATIONAL MONUMENT.

TABLE 7. CHAPARRAL AVIAN GRANIVORES AT PINNACLES NATIONAL MONUMENT AND HASTINGS NATURAL HISTORY RESERVATION

TABLE 8. POSSIBLE GENERA IN THE NORTHERN SALINAS VALEY $17 \mathrm{Ma}$ - QUATERNARY. 


\section{LIST OF ABBREVIATIONS}

\begin{tabular}{ll} 
CCDA & California Climate Data Archive \\
CIMIS & California Irrigation Management Information System \\
DC & Drought coefficient \\
ESRI & Environmental Systems Research Institute \\
GLM & General linear model \\
GPS & Global positioning system \\
HHSVRA & Hollister Hills State Vehicular Recreation Area \\
HNHR & Hastings Natural History Reservation \\
ka & Thousand years \\
Ma & Million years \\
NORM & Normalized \\
NVF & Neenach Volcanic Formation \\
PCRP & Palo Corona Regional Park \\
PNM & Pinnacles National Monument \\
PVF & Pinnacles Volcanic Formation \\
SAF & San Andreas fault \\
SE & Standard error \\
SRTM & Shuttle Radar Topography Mission \\
TCP & Toro County Park \\
USGS & United States Geological Survey \\
\hline
\end{tabular}




\section{INTRODUCTION}

Taxonomy

Eriogonum Michx. (Polygonaceae), or wild buckwheat, is one of the largest genera in the North American flora. Most of the approximately 250 species of Eriogonum occur in arid, isolated regions of the American west and southwest. However, they are also found in Canada, Alaska, northern Mexico, and parts of the eastern United States (Reveal 2005).

Eriogonum is separated into eight subgenera that represent three lines of evolutionary development. The second line of development diverged between the late Miocene to early Pliocene $(8-5 \mathrm{Ma})$ from an extinct line and is represented by the subgenera Eucycla, Oligogonum, Eriogonum, and Pterogonum (Reveal 1969b, 1978; Shields and Reveal 1988).

The third line of development diverged from Eucycla and is represented by the subgenera Oregonium, Ganysma, and Micrantha (Reveal 1969b, 1978; Shields and Reveal 1988). The subgenus Oregonium diverged in the southern California Coast Ranges around the late Pliocene $(3-2 \mathrm{Ma})$, which was also the driest part of the Tertiary (Reveal 1978). Oregonium is comprised entirely of annuals (Reveal 1969b). Separation of species in Oregonium generally occurs by use of minor character distinctions or, commonly, geographic location (Reveal 1969b, 1978).

Eriogonum Michx. subg. Oregonium (S. Watson) Green nortonii E. Greene, (Polygonaceae), or Pinnacles wild buckwheat (Greene 1892; Fig. 1), 
was reduced by Stokes (1936) to the subspecies level under Eriogonum vimineum Douglas ex Bentham subsp. nortonii (Greene) S. Stokes. Reveal (1969b) later re-established E. nortonii as a distinct species.

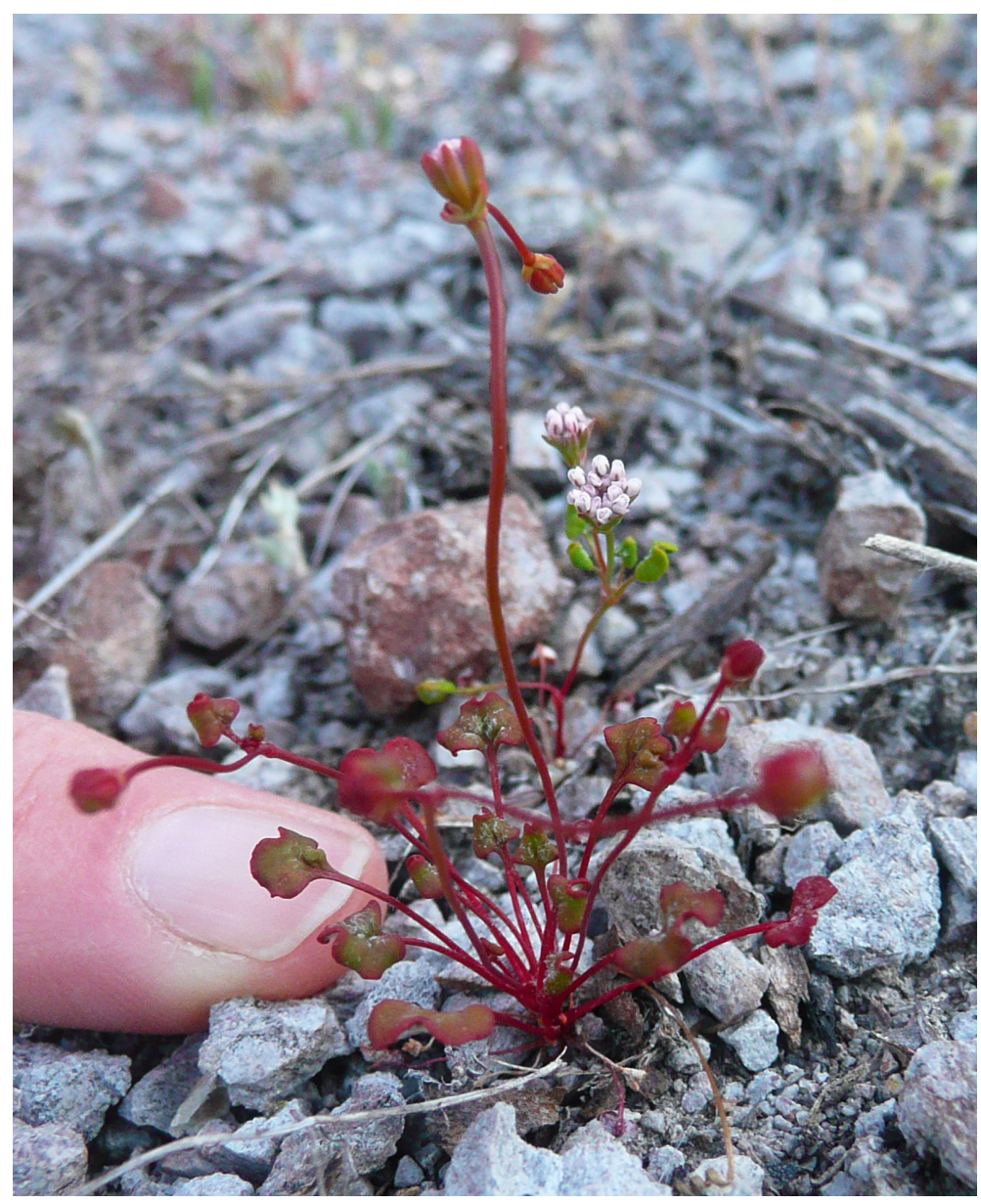

FIG. 1. Eriogonum nortonii. Photo courtesy Dr. Rod Myatt.

Eriogonum nortonii is an erect annual with \pm ascending red, glabrous stems ranging in height from $0.5-20.0 \mathrm{~cm}$. Both basal and cauline leaves are red to greenish-red, $0.5-1.5 \mathrm{~cm}$ wide, with round to reniform, wavy margined blades that are adaxially glabrous to puberulent and abaxially white-tomentose. The cymose inflorescence is subtended by a glabrous involucre having eight 
teeth, which is further subtended by glabrous bracts $1-2 \mathrm{~mm}$ long. Flowers are $1-2 \mathrm{~mm}$ in diameter, and perianths are deep pink to white. Each flower produces a single, light brown, glabrous achene, which typically falls from the parent plant with the calyx intact (Reveal 1969b; Hickman 1993). The flowering period has been observed as early as February and as late as September, but primarily occurs March through June.

\section{Ecology}

Eriogonum nortonii is a rare species restricted to the Monterey and San Benito County Coast Ranges, California (Fig. 2). Populations occur in the Gabilan, Sierra de Salinas, and Santa Lucia Ranges between 300 and 1000 meters in elevation.

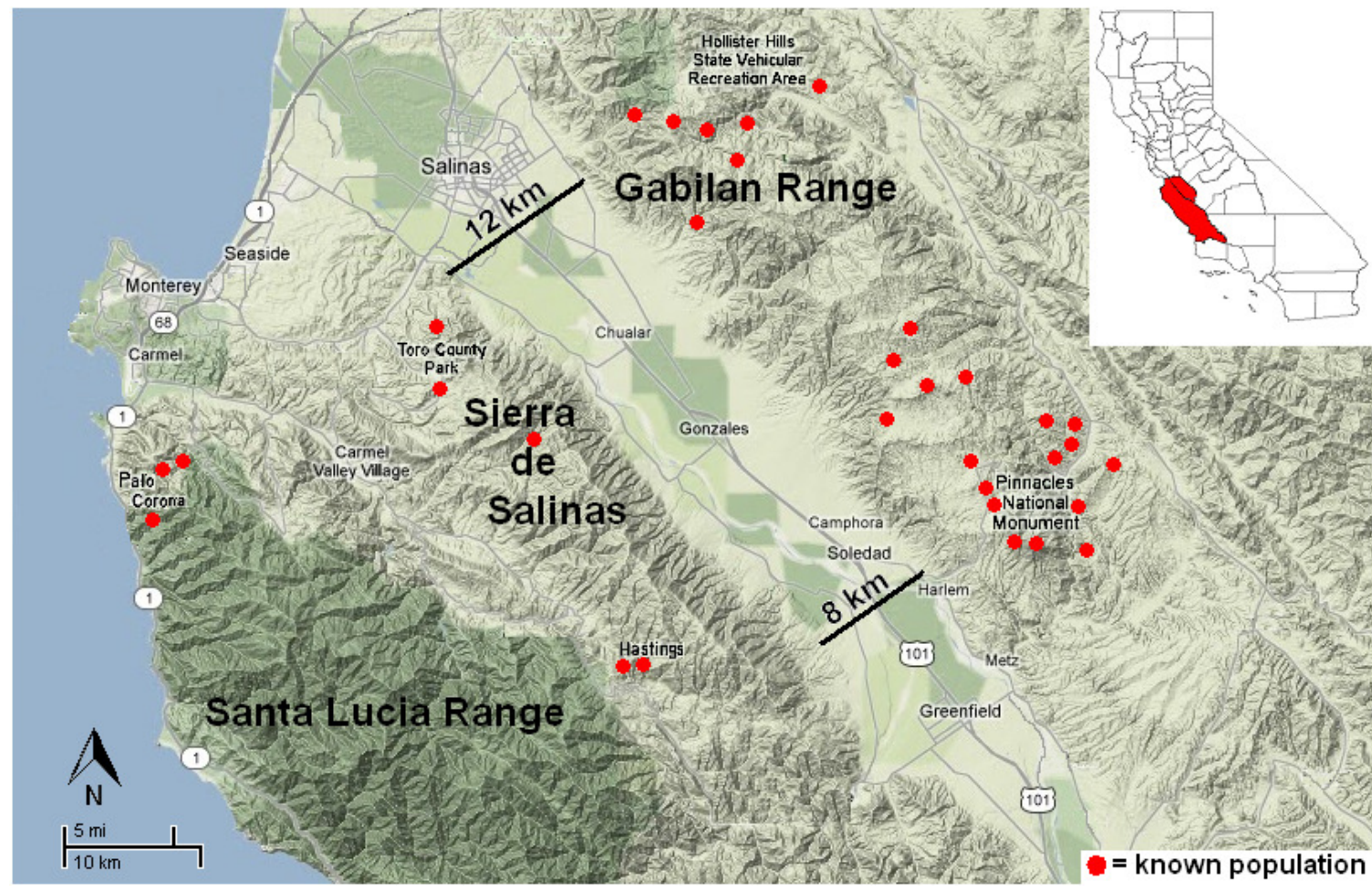

FIG. 2. Range of E. nortonii. Known populations (circle). Map data @ Google, INEGI 2012. 
The northern Salinas Valley is a sedimentary basin (Kilkenny 1948) between $12 \mathrm{~km}$ and $8 \mathrm{~km}$ wide that separates eastern populations of $E$. nortonii from western populations. Populations in the Gabilan Range, east of the Salinas Valley, occur where climate is more variable and has a wider range of extremes. Populations in the northern Sierra de Salinas and Santa Lucia Ranges, west of the Salinas Valley occur where the maritime climate is more moderate.

Eriogonum nortonii occurs in open pockets of chaparral; rarely do individuals occur under the shelter of adjacent shrubs (Fig. 3). The soils are generally shallow and gravelly.

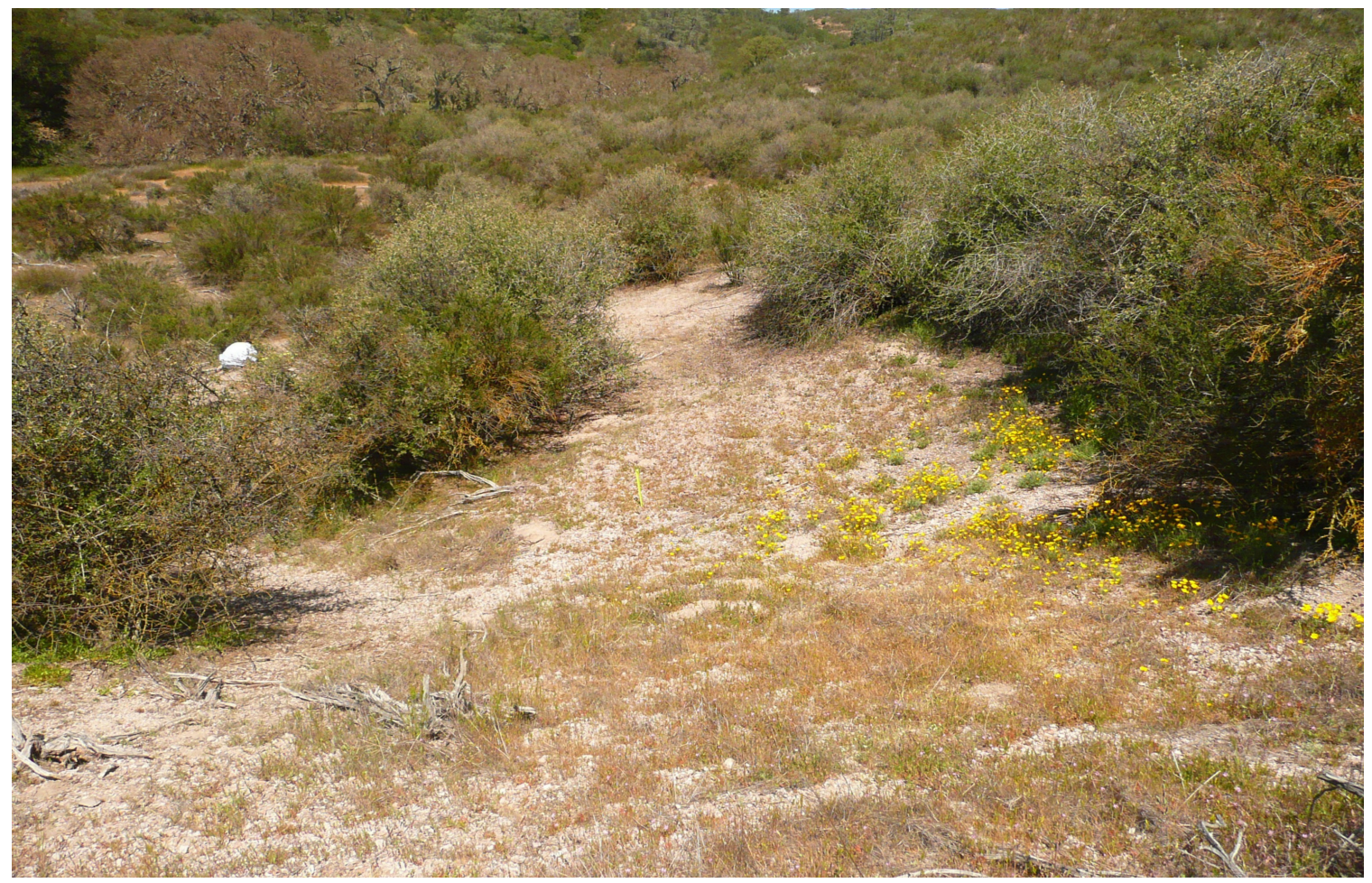

FIG. 3. Shrub interspaces in chaparral habitat at Pinnacles National Monument. Photo courtesy Dr. Rod Myatt. 


\section{Population Divergence}

Divergence between plant populations may occur where gene flow is limited between isolated populations or where populations occur under different environmental conditions. The separation of $E$. nortonii populations by the Salinas Valley and their occurrence in sites with different climate patterns suggest that divergence has occurred. However, other factors indicate that $E$. nortonii and its distribution are of recent origins and, thus, have not accrued the time for divergence to occur.

Stebbins and Major (1965) suggested that species with restricted distributions that are separated from their conspecifics by minor character distinctions have recently speciated. As previously mentioned, Eriogonum nortonii is a member of the subgenus Oregonium, which is comprised of member species that are morphologically very similar. In addition, most species in Oregonium, including E. nortonii, have narrow distributions, which suggests they have not had time to expand their ranges.

Moreover, there may be an association between environments of recent origin and young plant taxa (Stebbins and Major 1965). Recent changes in the topography in the northern Salinas Valley have occurred within the last two million years (Christensen 1965; Page et al. 1998; Ducea et al. 2003). The Mediterranean climate regime in the northern Salinas Valley and the chaparral associations where $E$. nortonii occurs may also be relatively youthful ( $2 \mathrm{Ma}-$ 10 ka; Axelrod 1981). 
Additionally, the range expansion of small annuals like E. nortonii was likely made possible by the range expansion of surrounding xeric shrubland as climate became more arid. Given the relatively recent origins of the present climate regime and consequent changes to a more xeric flora, it is likely that the occurrence of $E$. nortonii on opposite sides of the Salinas Valley is also recent. Thus, the possibility that divergence between populations on opposite sides of the Salinas Valley has occurred is less likely.

The primary objective of this study was to determine whether divergence has occurred between populations of E. nortonii on opposite sides of the Salinas Valley through comparison of morphological features and habitat parameters. Additionally, a literature review focuses on the biogeography of $E$. nortonii by considering the paleoenvironment of Eriogonum as well as contemporary environmental and dispersal parameters that may have contributed to the present distribution of $E$. nortonii.

\section{MATERIALS AND METHODS}

\section{Study Sites}

A total of 14 E. nortonii study sites spread across five locations were sampled within the Gabilan, Sierra de Salinas, and Santa Lucia Ranges in Monterey and San Benito Counties, California (Fig. 4). Sites were selected based on the extent of $E$. nortonii's range. At each site, abiotic factors were measured and plots were established to sample individual plant traits. 


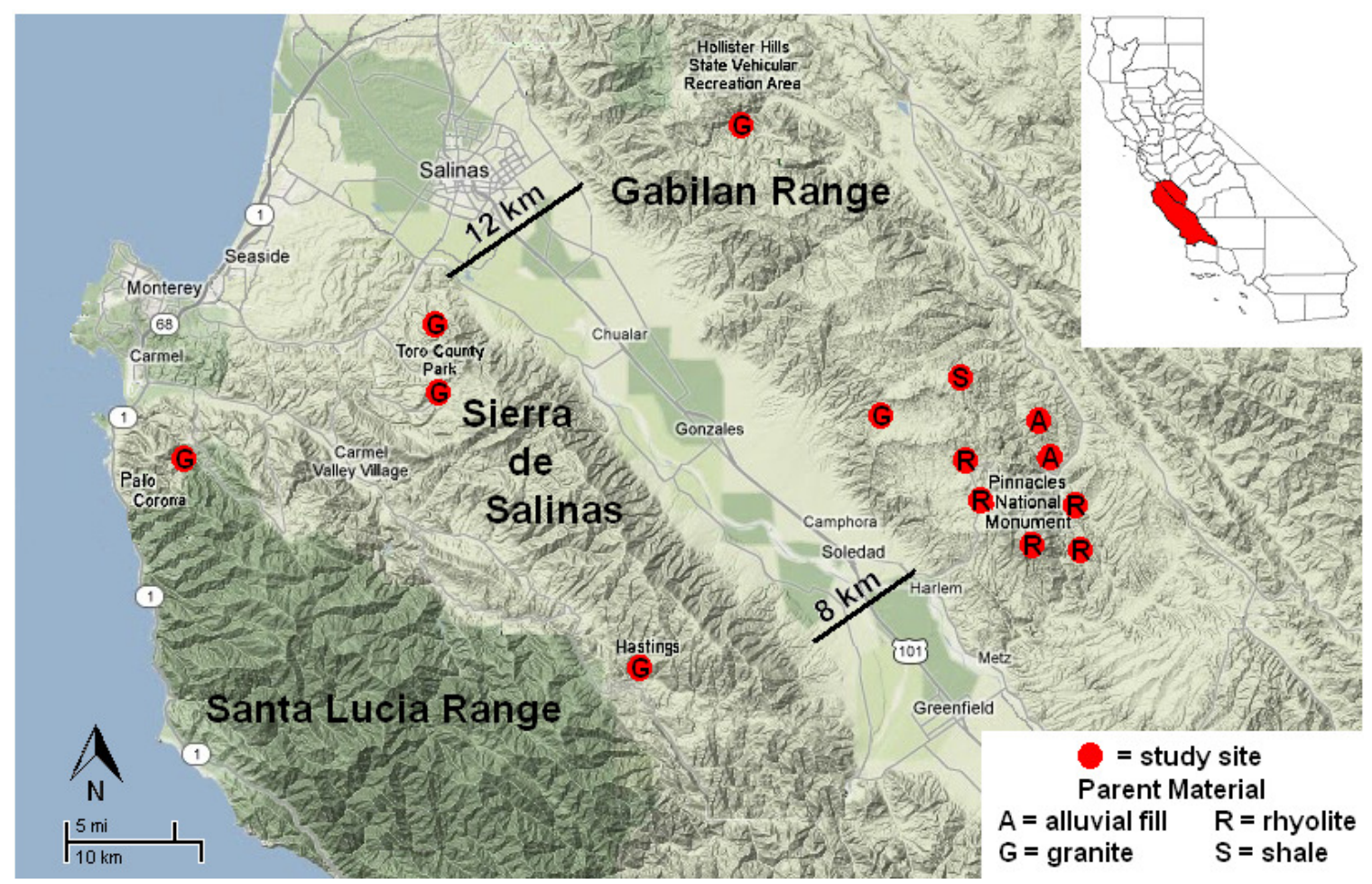

FIG. 4. Study area in Monterey and San Benito Counties (inset) with 14 study sites (circle) and associated parent material (A, G, R, S). Map data () Google, INEGI 2012.

Gabilan Range. One site was sampled at Hollister Hills State Vehicular Recreation Area (HHSVRA; $36^{\circ} 47^{\prime} \mathrm{N}, 121^{\circ} 25^{\prime} \mathrm{W}$ ) located at the northern end of the Gabilan Range, $9.6 \mathrm{~km}$ southeast of Hollister, California. While HHSVRA is used year-round for off-road vehicle recreation, the study site is in a protected area of the park to the side of a hiking trail. Annual precipitation of $30-50 \mathrm{~cm}$ falls primarily between late October and late April. Temperatures range between lows of $-8{ }^{\circ} \mathrm{C}$ and highs of $43{ }^{\circ} \mathrm{C}$ (California Irrigation Management Information System, CIMIS 2009). Soils are derived from granitic parent material (Dibblee 1975). Associated shrubs outside sampling plots included Adenostoma 
fasciculatum Hook. \& Arn. (chamise), Salvia mellifera E. Greene (black sage), and Mimulus aurantiacus Curtis (monkey flower; Table 1).

\begin{tabular}{|c|c|c|}
\hline Study Site & Parent Material & Dominant Vegetation \\
\hline HHSVRA & Granite & Chamise, black sage, monkey flower \\
\hline Gloria Valley & Granite & Chamise \\
\hline North Border & Shale & Chamise \\
\hline Chalone Creek & Fanglomerate & Chamise \\
\hline Bear Creek & Fanglomerate & Chamise, buckbrush, grey pine \\
\hline High Peaks & Rhyolite & Chamise \\
\hline Little Pinnacles & Rhyolite & Chamise, wild buckwheat, black sage \\
\hline North Chalone Peak & Rhyolite & Chamise, spike moss \\
\hline South Chalone Peak & Rhyolite & Chamise \\
\hline West Pinnacles & Rhyolite & Chamise, buckbrush \\
\hline Toro 1 & Granite & Chamise, black sage, manzanita \\
\hline Toro 2 & Granite & Chamise, black sage, manzanita \\
\hline HNHR & Granite & Chamise, black sage \\
\hline Palo Corona & Granite & $\begin{array}{l}\text { Chamise, monkey flower, manzanita, coffee } \\
\text { berry, poison-oak }\end{array}$ \\
\hline
\end{tabular}

A second site was sampled in Gloria Valley $\left(36^{\circ} 31^{\prime} \mathrm{N}, 121^{\circ} 18^{\prime} \mathrm{W}\right), \sim 6.7$

$\mathrm{km}$ west of the PNM border and $\sim 13.2 \mathrm{~km}$ east of Gonzalez, California, and eight sites were sampled at Pinnacles National Monument (PNM; 36 $29^{\circ} \mathrm{N}, 121^{\circ} 10^{\prime}$ W) located at the southern end of the Gabilan Range, $22.5 \mathrm{~km}$ east of Soledad, California (Fig. 5). Average daily summer temperatures range from $10{ }^{\circ} \mathrm{C}$ in the morning to $45^{\circ} \mathrm{C}$ in the afternoon. Precipitation ranges from 16 to $35 \mathrm{~cm}$ between December and March (California Climate Data Archive, CCDA 2008).

Gloria Valley and North Border were the two most northern sites within the Pinnacles area. Both sites occurred in chamise-dominant chaparral. Whereas the parent material at Gloria Valley was granitic, the North Border site was near Miocene marine diatomaceous shale (Matthews 1976; Soil Survey Geographic 
Database, USDA 2004). Soils with this shale are extremely white and infertile.

Woody plants on this soil are often widely spaced with sparse understory.

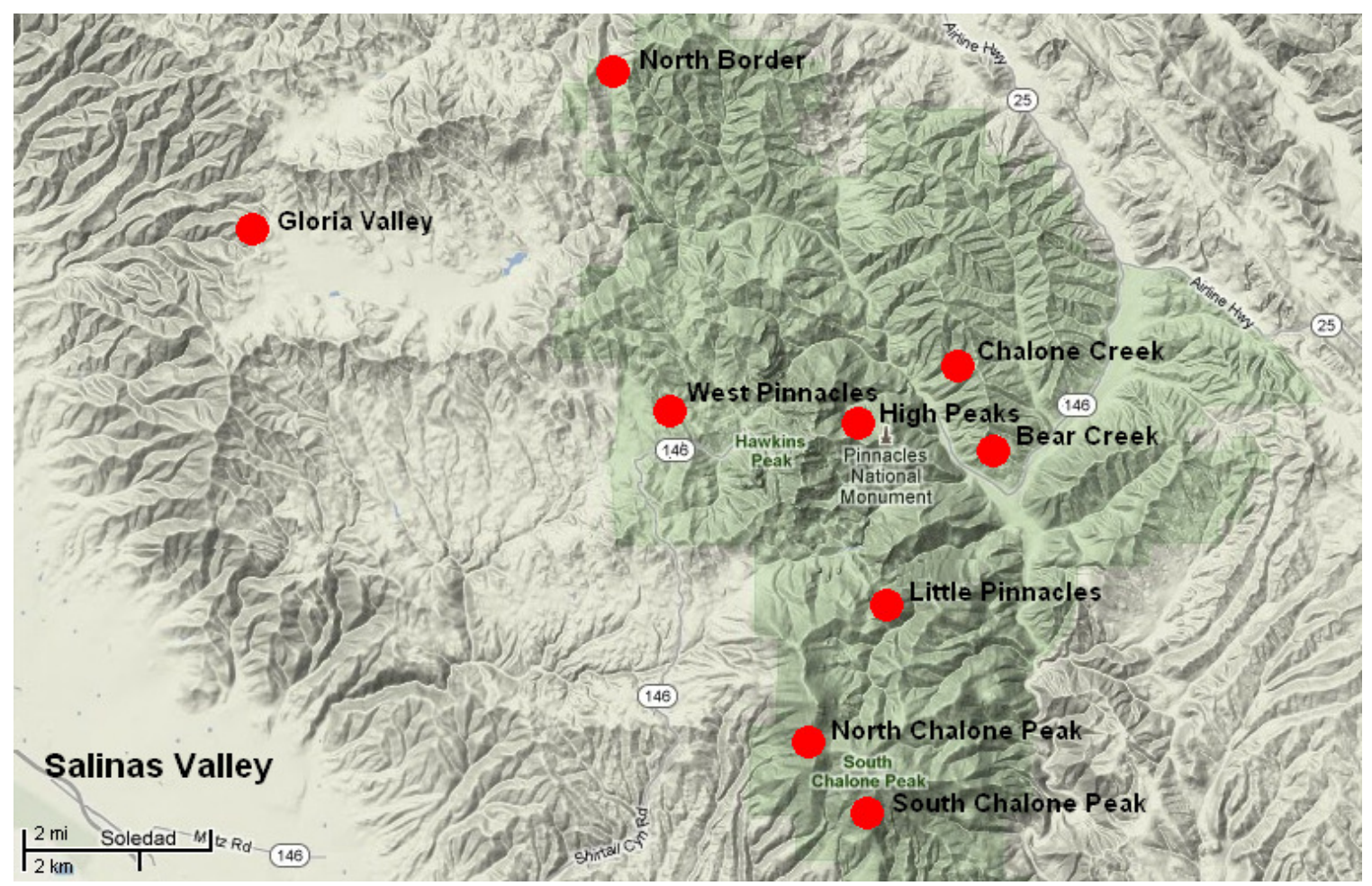

FIG. 5. Gloria Valley and Pinnacles National Monument study sites. Map data $\odot$ Google, INEGI 2012.

The Chalone Creek site, dominated by chamise, lay east of the Chalone Creek on soils from Miocene-aged alluvial fan material composed primarily of granite with some volcanics (Matthews 1976; USDA 2004). Southeast of the Chalone Creek site and also on alluvial fan soils was the Bear Creek site near the intersection of Chalone and Bear Creeks. This area had chamise, Ceanothus cuneatus (Hook.) (buckbrush) and Pinus sabiniana Douglas (grey pine). 
The High Peaks, Little Pinnacles Crest, North Chalone Peak, South Chalone Peak, and West Pinnacles sites were all on soils from rhyolite parent material (Matthews 1976; USDA 2004). The High Peaks site was completely surrounded by chamise. Further south, the Little Pinnacles site to the east of the North Chalone Peak Trail was in a relatively open area surrounded by chamise, Eriogonum fasciculatum Benth. (wild buckwheat), and black sage. The North Chalone Peak site, southwest of Little Pinnacles, was completely encircled by dense chamise for several meters on all sides. The most southerly site, South Chalone Peak, was in an open area of scree upslope from chamise with an understory of Selaginella bigellovii L. while the overstory at West Pinnacles was chamise and buckbrush.

Sierra de Salinas Range. Two sites were sampled at Toro County Park (TCP; $36^{\circ} 35^{\prime} \mathrm{N}, 121^{\circ} 41^{\prime} \mathrm{W}$ ) located at the northern end of the Sierra de Salinas Range, $9.0 \mathrm{~km}$ southwest of Salinas, California on Highway 68. Both sites were at the side of trails used for hiking and mountain biking. Annual temperatures range between $-2{ }^{\circ} \mathrm{C}$ and $36{ }^{\circ} \mathrm{C}$. Annual precipitation, between 21 and $48 \mathrm{~cm}$, occurs principally between November and April (CCDA 2008). Soils are derived from granitic parent material (Wagner et al. 2002), which supported associated woody taxa such as chamise, black sage, and Arctostaphylos sp. (manzanita) outside of sample plots.

One site was sampled at Hastings Natural History Reservation (HNHR; $36^{\circ} 23^{\prime} \mathrm{N}, 121^{\circ} 32 \mathrm{~W}$ ) on the west side of the Sierra de Salinas Range within the 
Carmel Valley $\sim$ one km west of Carmel Valley Road. The E. nortonii population there had emerged after a prescribed burn during winter 2007. Two prior observations of E. nortonii were made after the Poison Oak Hill fire in 1981 and the Haystack Hill fire in 1944. Both of those burns occurred in chaparral. Only one individual of $E$. nortonii was spotted after the Poison Oak Hill burn (Griffin 1995). Annual temperatures range from $-4.5^{\circ} \mathrm{C}$ to $38^{\circ} \mathrm{C}$. Precipitation falls between late October and April and ranges from 28 to $65 \mathrm{~cm}$ (CCDA 2008). Common associated overstory taxa included chamise and black sage on granitic soils (Wagner et al. 2002).

Santa Lucia Range. One site was sampled at Palo Corona Regional Park (PCRP; $36^{\circ} 29^{\prime} \mathrm{N}, 121^{\circ} 54^{\prime} \mathrm{W}$ ) on the west slope of the Santa Lucia Range in the Carmel Highlands $\sim 3 \mathrm{~km}$ east of Highway One. Temperatures range from $-3{ }^{\circ} \mathrm{C}$ to $34{ }^{\circ} \mathrm{C}$ while annual precipitation ranges from 23 to $104 \mathrm{~cm}$ and falls primarily between November and March (CCDA 2008). The E. nortonii population was in the middle of an old road that passed through maritime chaparral occurring on granitic soils (Wagner et al. 2002) and comprised of chamise, monkey flower, manzanita, Frangula californica (Eschsch.) A. Gray (coffee berry), and Toxicodendron diversilobum (Torrey \& A. Gray) E. Greene (poison-oak). 
Weather

Weather data (wind vectors, precipitation, air temperature, and humidity) were obtained from the CCDA and the CIMIS as daily climate measurements. Precipitation, air temperature, and humidity data are reported as ranges and monthly averages for the time period from September 2007 to August 2008. This period of weather data corresponds with a single generation of plants. The 2007 - 2008 E. nortonii generation is defined as extending from September 1, 2007, when fruit abscission from spring 2007 individuals was completed, to August 31, 2008, when spring 2008 individuals completed their lifecycles.

Selected climate stations were located as close to the study sites as possible (Fig. 6). The Hollister station ( $36^{\circ} 51^{\prime} \mathrm{N}, 121^{\circ} 24^{\prime} \mathrm{W} ; 84 \mathrm{~m}$ ) was located approximately $7.1 \mathrm{~km} \mathrm{NW}$ of the HHSVRA site. The Pinnacles station $\left(36^{\circ} 28^{\prime} \mathrm{N}\right.$, $121^{\circ} 08^{\prime} \mathrm{W} ; 403 \mathrm{~m}$ ) was located $7.9 \mathrm{~km}$ and $12.1 \mathrm{~km}$ SE of the North Border and Gloria Valley sites, respectively; $0.4 \mathrm{~km} \mathrm{SW}$ of the Chalone Creek site; $5.1 \mathrm{~km} \mathrm{E}$ of the West Pinnacles site; $3.0 \mathrm{~km} \mathrm{NW}$ of the Bear Creek site; $3.1 \mathrm{~km} \mathrm{~N}$ of the Little Pinnacles site; and 2.1 km, $9.2 \mathrm{~km}$ and $10.2 \mathrm{~km}$ NE of the High Peaks, North Chalone Peak, and South Chalone Peak sites, respectively. The Fort Ord station $\left(36^{\circ} 35^{\prime} \mathrm{N}, 121^{\circ} 45^{\prime} \mathrm{W} ; 234 \mathrm{~m}\right.$ ) was located $10.1 \mathrm{~km}$ and $12.2 \mathrm{~km} \mathrm{NW}$ of the Toro 1 and Toro 2 sites, respectively. The Hastings station $\left(36^{\circ} 23^{\prime} \mathrm{N}, 121^{\circ}\right.$ 33' W; $574 \mathrm{~m}$ ) was located $1.1 \mathrm{~km} \mathrm{NW}$ of the Hastings site. The Monterey station $\left(36^{\circ} 36^{\prime} \mathrm{N}, 121^{\circ} 54^{\prime} \mathrm{W}\right.$; $117 \mathrm{~m}$ ) was located $9.5 \mathrm{~km}$ NE of the Palo Corona site. 


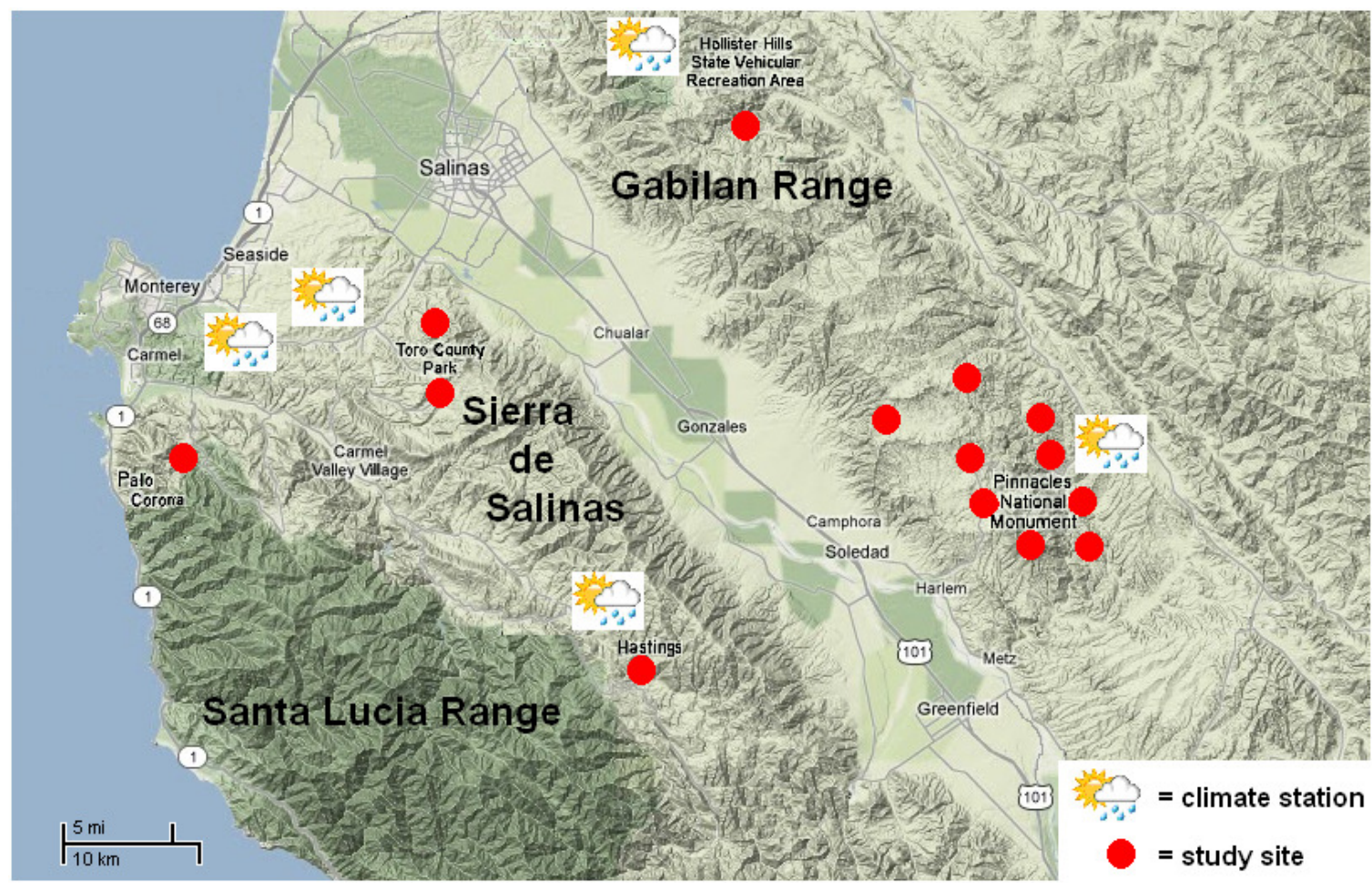

FIG. 6. Climate stations (weather image) and study sites (circle). Map data @ Google, INEGI 2012.

\section{Site and Plot Sampling}

All sampling was done between April and May 2008. For each site, elevation was taken using a GPS unit (Garmin 60CSx, Garmin Ltd., Olathe, Kansas), while slope and aspect were derived from the average of 3 - 5 measurements made with a compass (Suunto MC-2, Suunto, Vantaa, Finland). At each site, random $1 \mathrm{~m}^{2}$ plots were established to sample $10 \%$ of the site area. Some sites required more plots than others. Morphological and phenological measurements were made on plants within plots. Morphological measurements included plant height, width of largest leaf, and total number of inflorescences. A simple phenological scale was utilized to describe the relative 
stage of flowering for each population at the time of sampling where $1=$ all buds, $2=$ mixture of buds and open flowers, and $3=$ all open flowers.

Statistical Analyses

Wind roses were created to model potential paths for dispersal of $E$. nortonii seed. Raw wind data were aggregated by compass direction at $45^{\circ}$ intervals and weighted by wind speed. The resulting datasets were expressed as wind roses overlain on 8 SRTM (Shuttle Radar Topography Mission) one-arc second digital elevation datasets downloaded from the USGS Seamless Server using ARCMAP 9.2 (ESRI 2006, Redlands, CA).

Normalized (NORM) monthly averages of temperature $(T)$, relative humidity $(H)$, and precipitation $(P)$ were used to compute drought coefficients $(D C)$ where $D C=T_{\text {NORM }}+\left(100 \%-H_{\text {NORM }}\right)+\left(100 \%-P_{\text {NORM }}\right)$.

A nested General Linear Model (GLM) analyzed climate variables (relative humidity, air temperature, and cumulative precipitation), morphological variables (largest leaf width, height, and number of inflorescences), habitat characteristics (slope, aspect, and elevation), and population density by incorporating a fourlevel geographic hierarchy: orientation, range, location, and population (Fig. 7).

Orientation, the most inclusive level of the hierarchy, defined the range of E. nortonii in terms of the location of populations relative to the Salinas Valley. Therefore, populations could be oriented either east or west of the Salinas Valley. Mountain range, the second level, classified populations based on their locations within the Gabilan, the Sierra de Salinas, or the Santa Lucia Range. 


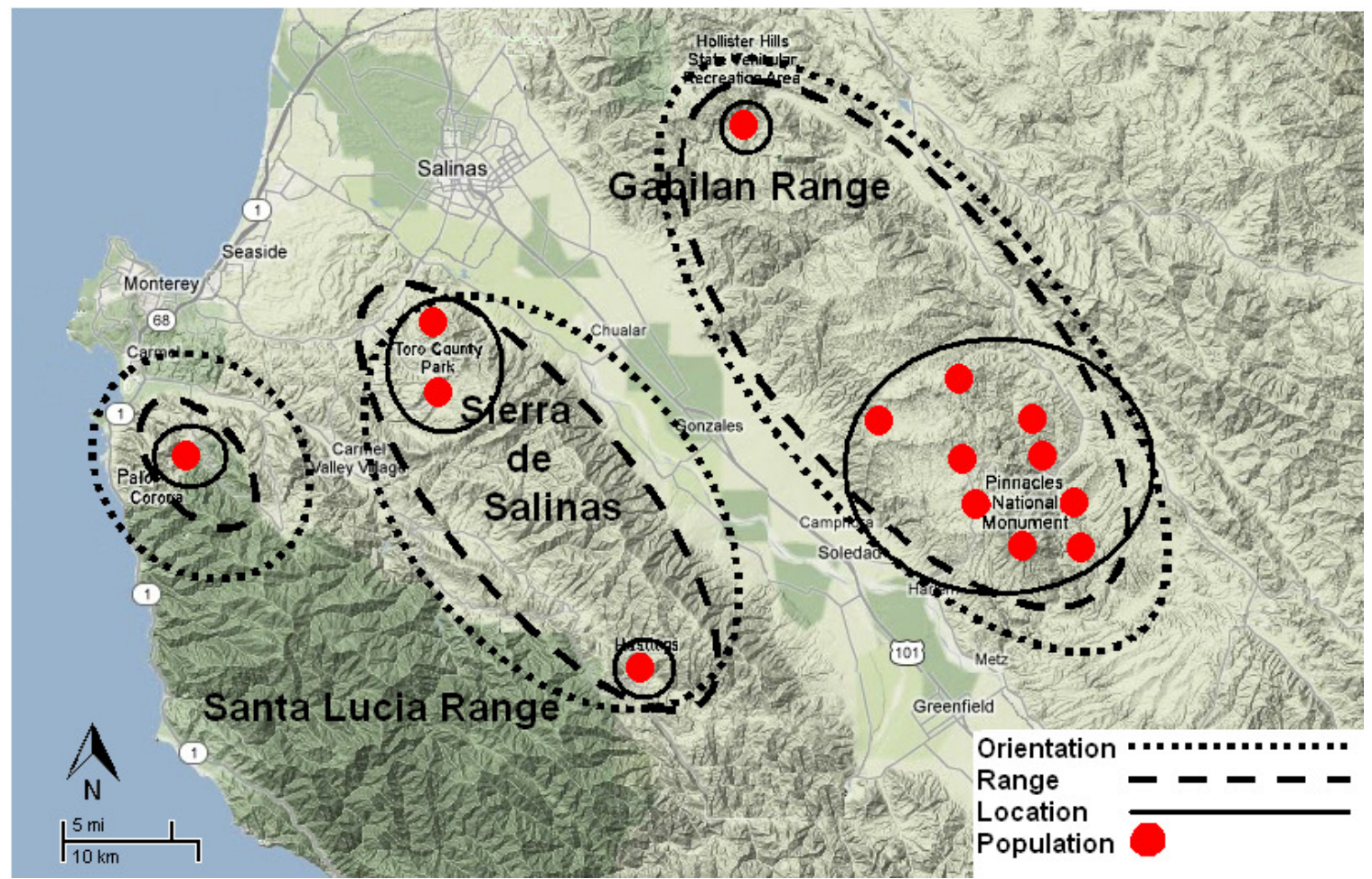

FIG. 7. Nested GLM model incorporating four geographic levels within the distribution of E. nortonii. Map data @ Google, INEGI 2012.

Location, the third level, divided the distribution of E. nortonii by five distinct locations: the northern Gabilan Range represented by HHSVRA, the southern Gabilan Range represented by the Pinnacles and Gloria Valley populations, the northern Sierra de Salinas represented by the Toro County Park populations, the central Sierra de Salinas represented by the Hastings population, and the northern Santa Lucia represented by the Palo Corona population. Individual study sites, the most discrete units within the range of $E$. nortonii, formed the fourth level, population. The resultant model required the geographic levels be incorporated or "nested" within more inclusive geographic areas. As such, population was nested within location, range, and orientation; location was 
nested within range and orientation; mountain range was nested within orientation.

All analyses were completed using Minitab 15 Statistical Software (Minitab Inc., State College, PA, 2006). Levene's test evaluated residuals for homogeneity of variance while the Anderson-Darling test assessed for the normal distribution of data. Post hoc tests on significant results $(\alpha=0.05)$ were analyzed using Tukey-Kramer Simultaneous Tests. Data that did not meet the assumptions of normality and homogeneity were transformed. A log transformation was used for leaf width, plant height, and slope. Despite transformation, relative humidity, air temperature, and precipitation failed to meet the assumptions of normality and homogeneity.

\section{RESULTS}

\section{Weather}

Wind rose models indicated variable patterns of flow across sites.

Dominant ESE vectors flowed from the coast across the Salinas Valley and from the NW down the Salinas Valley from September 2007 to August 2008. The Fort Ord climate station reported a dominant eastward wind off of Monterey Bay with secondarily important NE vectors (Fig. 8). The Hollister and Pinnacles stations indicated strong southeast flows down San Benito Valley and secondary westerly winds across the Gabilan Range. The Hastings station indicated approximately equivalent east and west-flowing winds with a secondarily important southeast wind up Carmel Valley. 


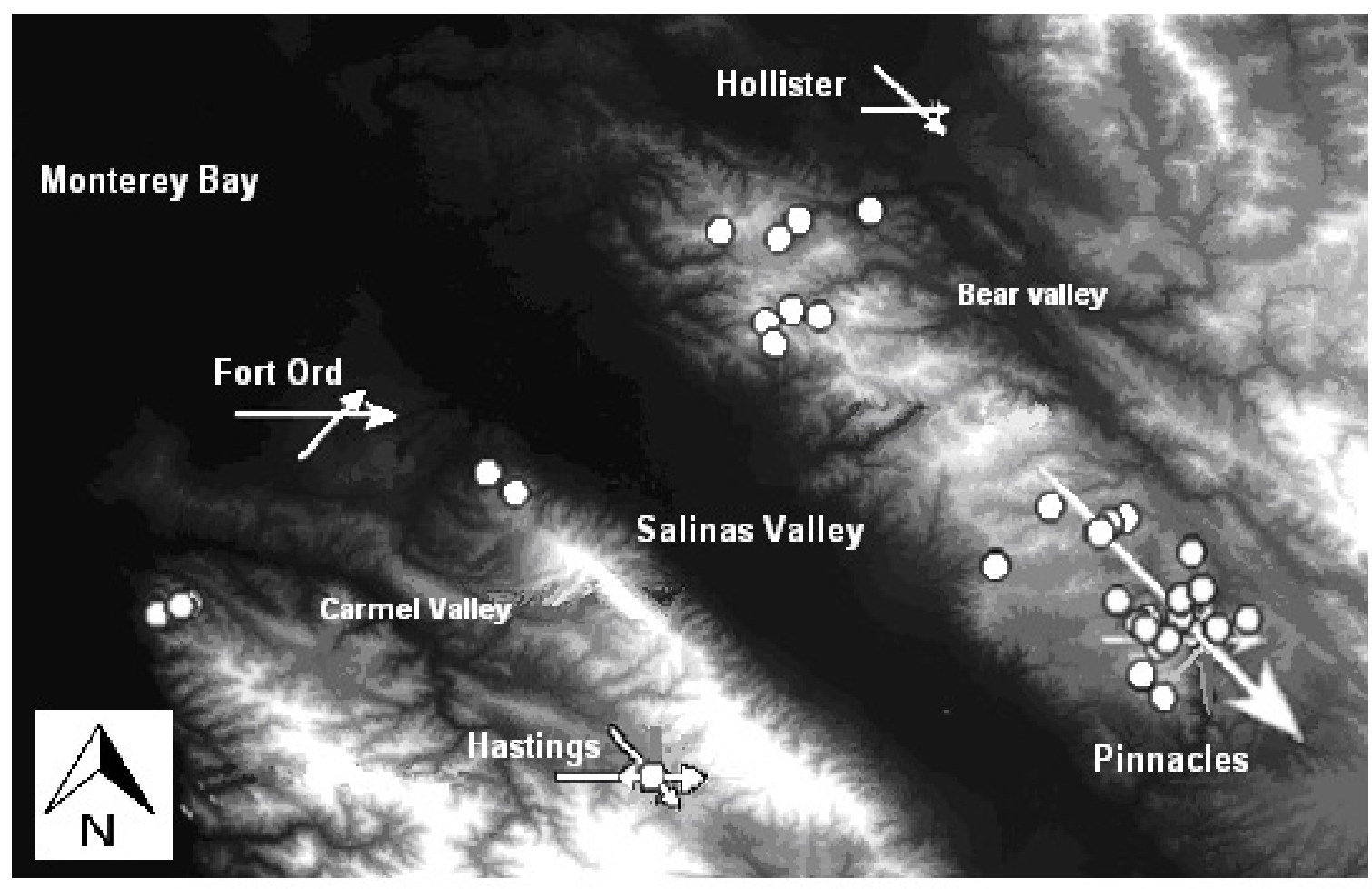

FIG. 8. Eight SRTM one-arc digital elevation datasets for the northern Salinas Valley region overlain by dominant wind vectors (arrows) for September 2007 - August 2008 and covering the range of $E$. nortonii (circles). SRTM data courtesy of the USGS 2007.

Weather patterns varied across climate stations as well as between the east and west sides of the Salinas Valley. Drought coefficients defined general climate trends in terms of moisture received at each of the five climate stations (Fig. 9). Climate stations east of the Salinas Valley generally received less moisture than climate stations west of the Salinas Valley as also indicated by individual climate parameters, precipitation, temperature, and humidity (Fig. 10).

Most variation across the five climate stations was reflected in precipitation patterns primarily from December 2007 through March 2008. Precipitation at Hastings $(47.8 \mathrm{~cm})$ was greatest while inland stations generally received less than coastal stations. 


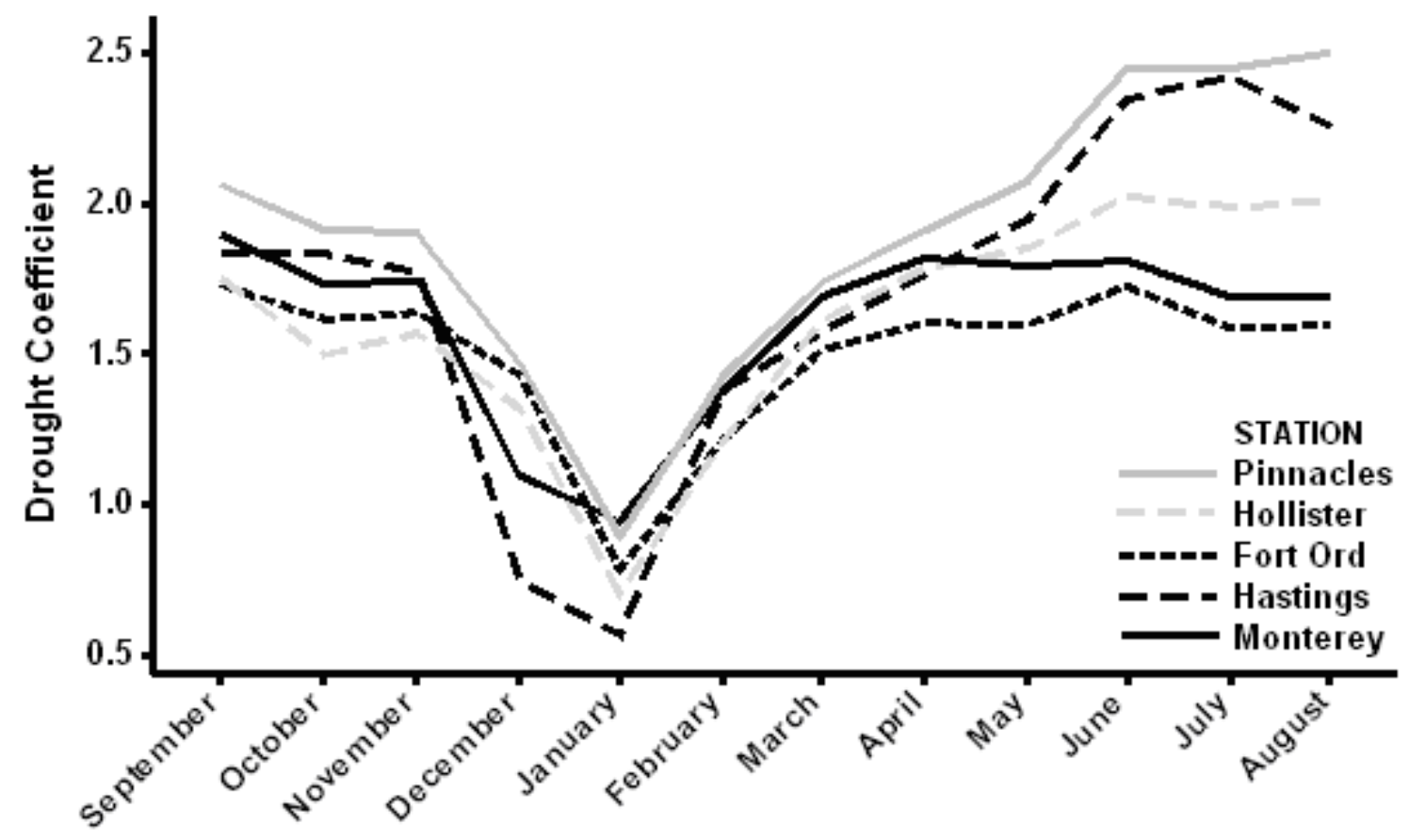

Month

FIG. 9. Drought coefficients from weather data across five climate stations for the September 2007 to August 2008 study period.

Temperature and humidity varied most between coastal and inland sites from June to August 2008. Average temperatures at Fort Ord and Monterey ranged between 10 to $15^{\circ} \mathrm{C}$ and Pinnacles between 20 to $25^{\circ} \mathrm{C}$. Hastings, located in the rain shadow of the Santa Lucia Range, behaved more like an inland site during the summer months where temperature ranged between 18 to $22{ }^{\circ} \mathrm{C}$.

Summer fog resulted in higher humidity at coastal sites $(60-85 \%)$ than at inland sites $(35-75 \%)$, where humidity values generally declined throughout the summer drought period. 

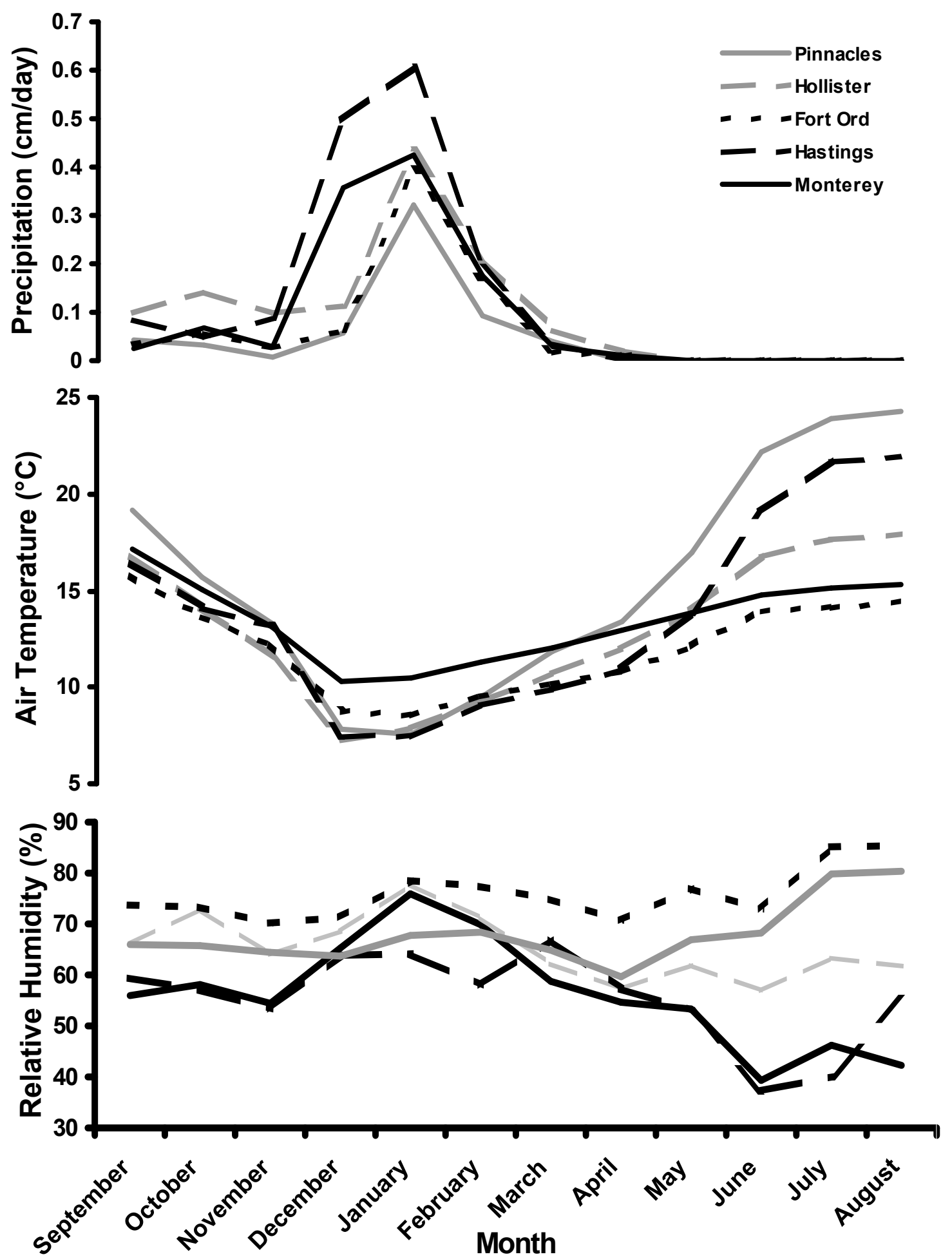

FIG. 10. Monthly averages of daily mean precipitation (cm/day), temperature $\left({ }^{\circ} \mathrm{C}\right)$, and relative humidity (\%) for five climate stations from September 2007 to August 2008. 


\section{Topographic Parameters}

Multiple comparisons of topographic parameters (elevation, aspect, and slope) across 14 E. nortonii sites indicated little significant variability overall with some exceptions (Fig. 11). Comparisons between elevations did not yield significant results at the orientation $\left(F_{1,2}=0.001 ; P=0.929\right)$, range $\left(F_{1,3}=0.01\right.$; $P=0.934)$, or location levels $\left(F_{2,5}=0.48 ; P=0.626\right)$.

Multiple comparisons did indicate variability in aspect at the orientation level $\left(F_{1,2}=5.87 ; P=0.042\right)$, but not the range level $\left(F_{2,4}=2.04 ; P=0.193 ;\right.$ Fig. 11). Aspects at E. nortonii study sites east of the Salinas Valley ranged from SSE to SW $\left(209 \pm 31^{\circ}\right)$ while study sites west of the Salinas Valley had a broader range of aspects from SE to $\mathrm{W}\left(177 \pm 34^{\circ}\right.$; Tukey-Kramer Post Hoc Test, $\mathrm{P}=$ 0.0416).

Multiple comparisons of slope indicated variability at the orientation, range, and population levels (Fig. 11; Table 2$)$. Mean slopes $\left(F_{1,2}=35.91 ; P<\right.$ $0.0001)$ east of the Salinas Valley $(19.7 \pm 7.0 \%)$ were steeper than slopes west of the Salinas Valley $(12.5 \pm 7.2 \%$; Tukey-Kramer Post Hoc Test, $\mathrm{P}<0.0001)$.

Of the three mountain ranges $\left(F_{1,3}=72.87 ; P<0.0001\right)$, the Santa Lucia Range $(8.6 \pm 3.0 \%)$ differed significantly from the Gabilan (19.7 $\pm 7.0 \%$; Tukey-Kramer Post Hoc Test, $P<0.0001)$ and the Sierra de Salinas Ranges $(20.8 \pm 6.6 \%$; Tukey-Kramer Post Hoc Test, $\mathrm{P}<0.0001)$. Slope comparisons across study sites $\left(F_{9,14}=2.69 ; P=0.009\right)$ indicated steepest slopes at HHSVRA and Hastings. Palo Corona had the gentlest slope. 

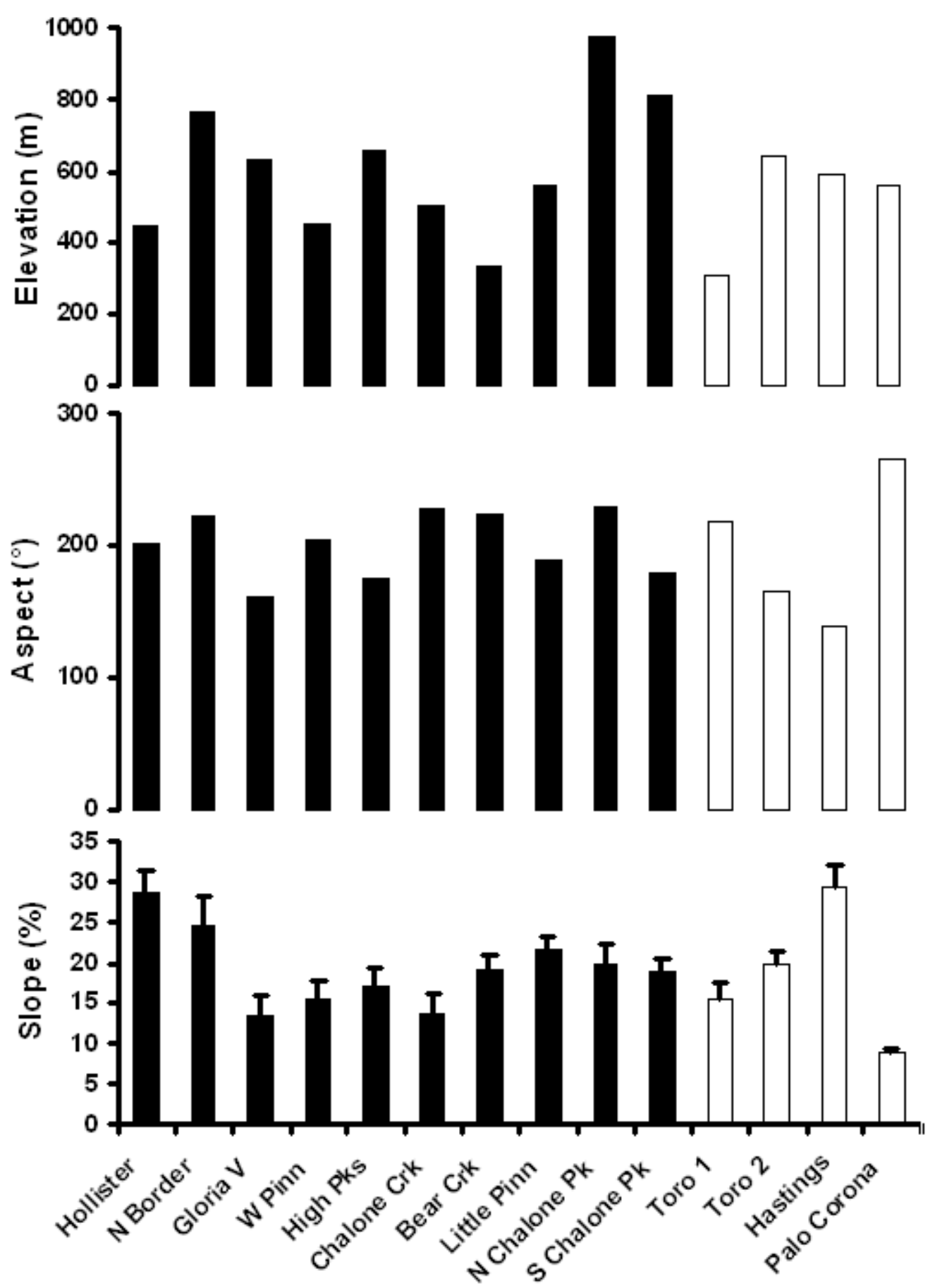

Study Site

FIG. 11. Elevation $(\mathrm{m})$, aspect $\left({ }^{\circ}\right)$, and mean slope (\%; \pm SE) at $14 \mathrm{E}$. nortonii study sites arranged north to south and aggregated by orientation east or west of the Salinas Valley. 
TABLE 2. MEAN SLOPE (\%) COMPARISONS BETWEEN E. NORTONII STUDY SITES AGGREGATED BY ORIENTATION EAST AND WEST OF THE SALINAS VALLEY.

$P$-values for each comparison indicate a significant difference between two study sites. $\mathrm{HH}=$ HHSVRA; NB = North Border; GV = Gloria Valley; WP = West Pinnacles; HP = High Peak; CC $=$ Chalone Creek; BC = Bear Creek; LP = Little Pinnacles; NC = North Chalone Peak; SC =

South Chalone Peak; T1 = Toro 1; T2 = Toro 2; HA = Hastings; $\mathrm{PC}=$ Palo Corona. ${ }^{*} \mathrm{P}<$ $0.0001 ;{ }^{* *} \mathrm{P}<0.005 ;{ }^{* * *} \mathrm{P}<0.05$ Tukey-Kramer simultaneous tests used in nested GLM.

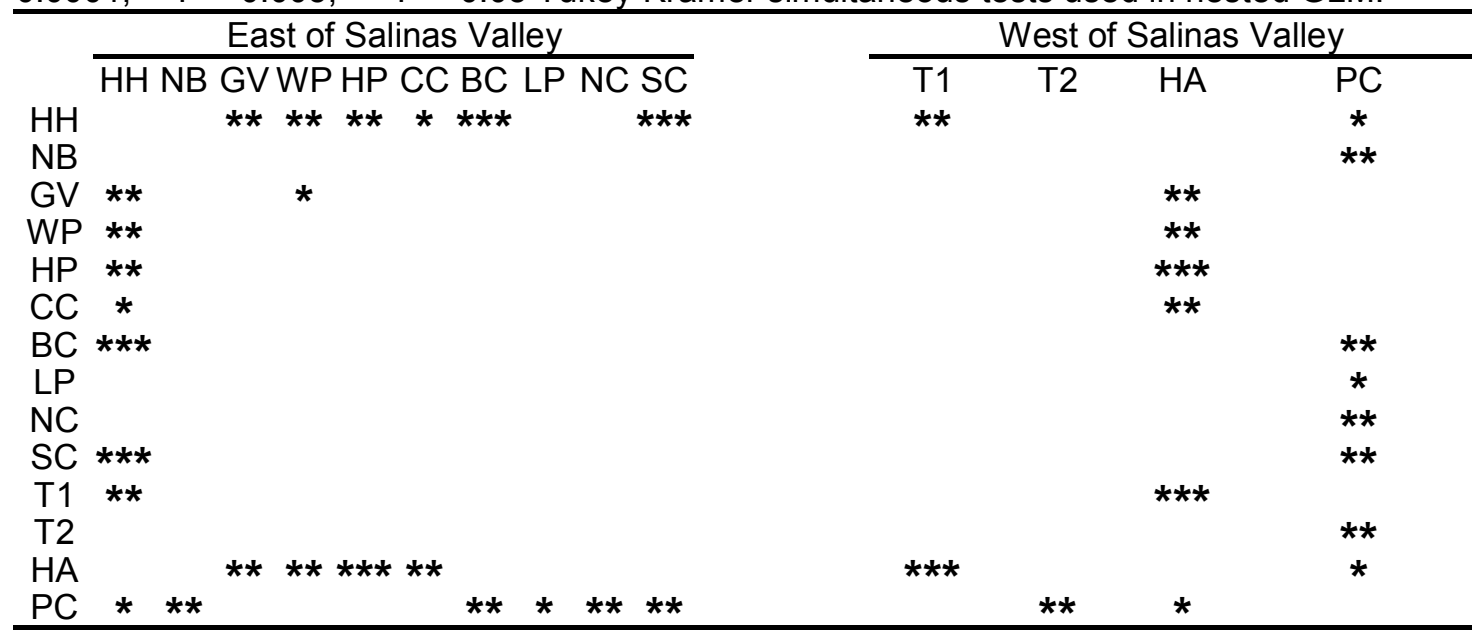

Morphological Characters

Overall, multiple comparisons of morphological characters did not indicate significant differences between populations east of the Salinas Valley with populations west of the Salinas Valley. However, there were some noticeable trends when comparisons of morphological characters were made across all populations. Average number of inflorescences per individual did not vary significantly by orientation $\left(F_{2,1}=0.02 ; P=0.889\right)$, range $\left(F_{2,1}=0.02 ; P=\right.$ $0.889)$, location $\left(F_{3,1}=0.13 ; P=0.723\right)$, or population $\left(F_{2,1}=0.33 ; P=0.953\right)$. Nevertheless, E. nortonii individuals in the Chalone Creek population had, on average, more inflorescences (average of 3 inflorescences per individual) than did individuals in other populations east or west of the Salinas Valley. Individuals in the North Border, South Chalone Peak, and High Peaks populations had fewer 
inflorescences (average of one inflorescence per individual) than did individuals in other populations east or west of the Salinas Valley (Fig. 12).

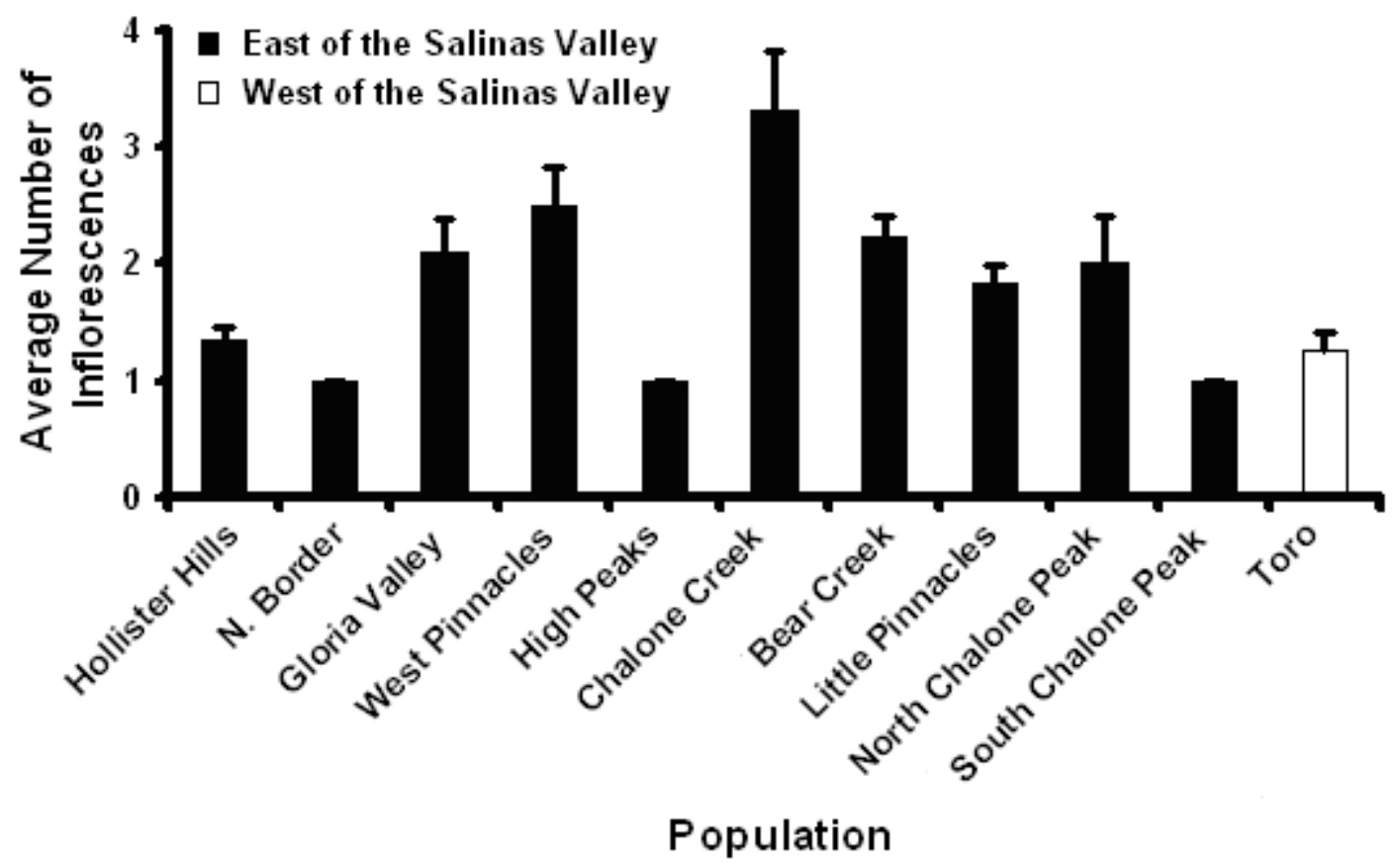

FIG. 12. Average number of inflorescences $( \pm$ SE) per $E$. nortonii individual at 11 sites arranged north to south and aggregated by orientation east or west of the Salinas Valley.

Multiple comparisons of mean leaf width between E. nortonii populations east versus populations west of the Salinas Valley did not yield significant differences $\left(F_{1,2}=1.42 ; P=0.234 ;\right.$ Fig. 13; Table 3). However, there were significant average leaf width differences from comparisons made across all $E$. nortonii populations $\left(\mathrm{F}_{8,11}=9.64 ; \mathrm{P}<0.0001\right)$ where North Chalone Peak and West Pinnacles populations had wider leaves (3.1 $\mathrm{mm}$ and $2.7 \mathrm{~mm}$, respectively) than five and six other populations, respectively, and the South Chalone Peak population had narrower leaves $(1.1 \mathrm{~mm})$ than eight other populations. 
TABLE 3. MEAN LEAF WIDTH COMPARISONS BETWEEN E. NORTONII POPULATIONS AGGREGATED BY ORIENTATION EAST AND WEST OF THE SALINAS VALLEY. P-values for each comparison indicate a significant difference between two populations. $\mathrm{HH}=$ HHSVRA; NB = North Border; GV = Gloria Valley; WP = West Pinnacles; HP = High Peak; CC $=$ Chalone Creek; $\mathrm{BC}=$ Bear Creek; LP = Little Pinnacles; NC = North Chalone Creek; SC = South Chalone Peak; T1 = Toro 1. ${ }^{*} \mathrm{P}<0.0001 ;{ }^{* *} \mathrm{P}<0.005 ;{ }^{* *} \mathrm{P}<0.05$ Tukey-Kramer simultaneous tests used in nested GLM.

\begin{tabular}{|c|c|c|c|c|c|c|c|c|c|}
\hline & \multicolumn{8}{|c|}{ East of the Salinas Valley } & \multirow{2}{*}{$\frac{\text { West of the Salinas Valley }}{\mathrm{T} 1}$} \\
\hline & $\mathrm{HH}$ & NB GV & $\overline{W P}$ & $\mathrm{HP}$ & $\mathrm{CC}$ & BC LP & $\mathrm{NC}$ & $\mathrm{SC}$ & \\
\hline SC & *** & $* *$ & * & ** & * & $* * * *$ & * & & \\
\hline NB & & & * & & ** & $* * * * * *$ & * & & \\
\hline WP & * & * & & & & $* * *$ & & * & * \\
\hline NC & ** & * & & & & *** & & * & ** \\
\hline LP & & * & *** & & & & *** & * & \\
\hline $\mathrm{BC}$ & & * & * & & & & & * & \\
\hline $\mathrm{HP}$ & & & & & & & & ** & \\
\hline $\mathrm{CC}$ & & * & & & & & & * & \\
\hline GV & & & & & & & & ** & \\
\hline $\mathrm{HH}$ & & & * & & *** & & ** & *** & \\
\hline T1 & & & * & & & & ** & & \\
\hline
\end{tabular}

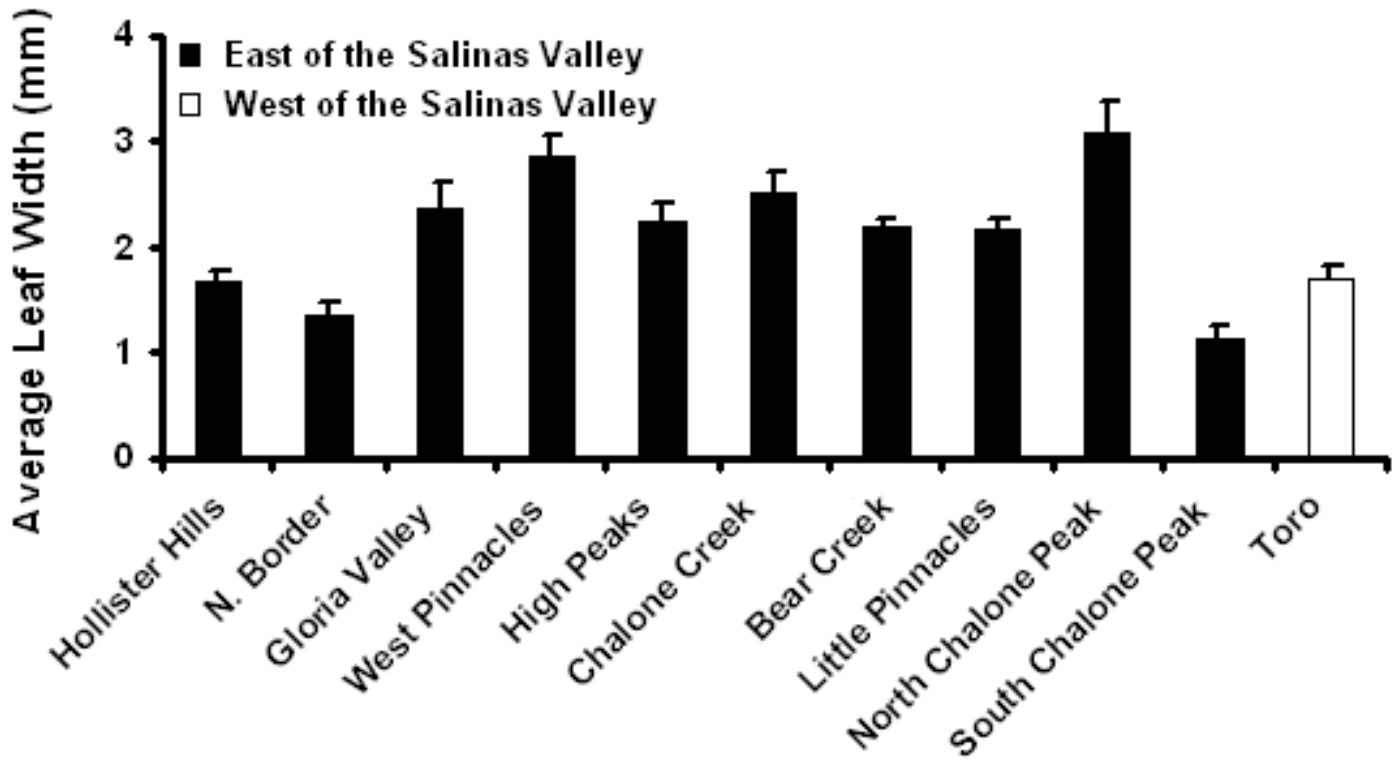

Population

FIG. 13. Average leaf width $(\mathrm{mm} ; \pm \mathrm{SE})$ across $11 \mathrm{E}$. nortonii populations arranged north to south and aggregated by orientation east or west of the Salinas Valley. 
While significant average plant height differences were not found in comparisons between E. nortonii populations east of the Salinas Valley and $E$. nortonii populations west of the Salinas Valley $\left(F_{2,1}=1.36, P=0.244\right)$, there were differences found amongst all 11 populations $\left(F_{8,11}=14.35, P<0.0001\right.$; Fig. 14; Table 4). Chalone Creek and Bear Creek Pinnacles populations had taller plants (35.7 mm and $32.7 \mathrm{~mm}$, respectively) than six and eight other populations, respectively, while the High Peaks and South Chalone populations had shorter plants (18.3 $\mathrm{mm}$ and $15.4 \mathrm{~mm}$, respectively) than five and seven other populations, respectively.

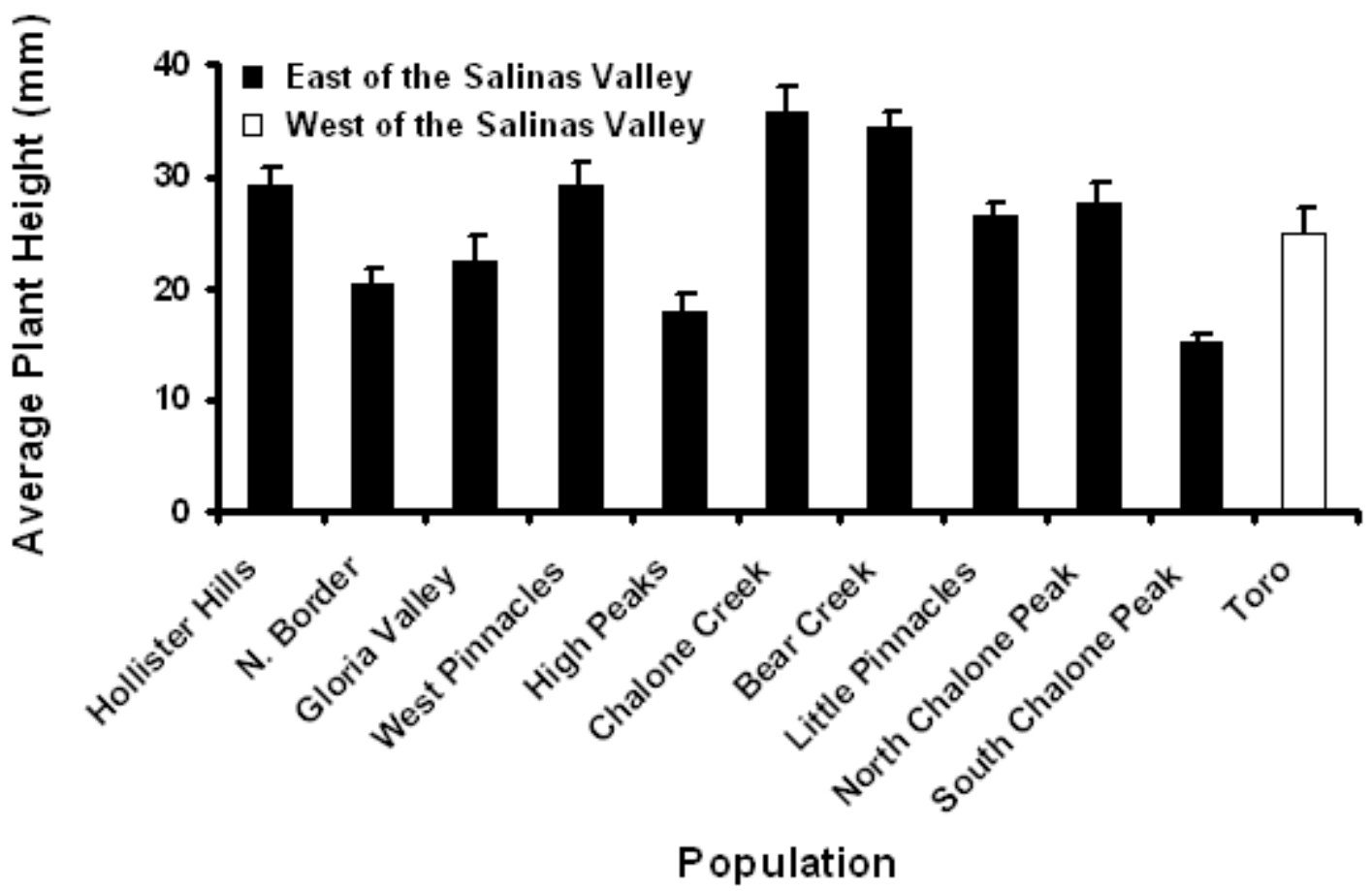

FIG. 14. Mean plant height ( $\mathrm{mm} ; \pm \mathrm{SE}$ ) across $11 \mathrm{E}$. nortonii populations arranged north to south and aggregated by orientation east or west of the Salinas Valley. 
TABLE 4. MEAN PLANT HEIGHT COMPARISONS BETWEEN E. NORTONII

POPULATIONS AGGREGATED BY ORIENTATION EAST AND WEST OF THE SALINAS

VALLEY. P-values for each comparison indicate a significant difference between two populations. HH = HHSVRA; NB = North Border; GV = Gloria Valley; WP = West Pinnacles; HP = High Peak; CC = Chalone Creek; BC = Bear Creek; LP = Little Pinnacles; NC = North Chalone Creek; $\mathrm{SC}=$ South Chalone Peak; $\mathrm{T} 1=$ Toro $1 .{ }^{*} \mathrm{P}<0.0001 ;{ }^{* *} \mathrm{P}<0.005 ;{ }^{* * *} \mathrm{P}<$ 0.05 Tukey-Kramer simultaneous tests used in nested GLM.

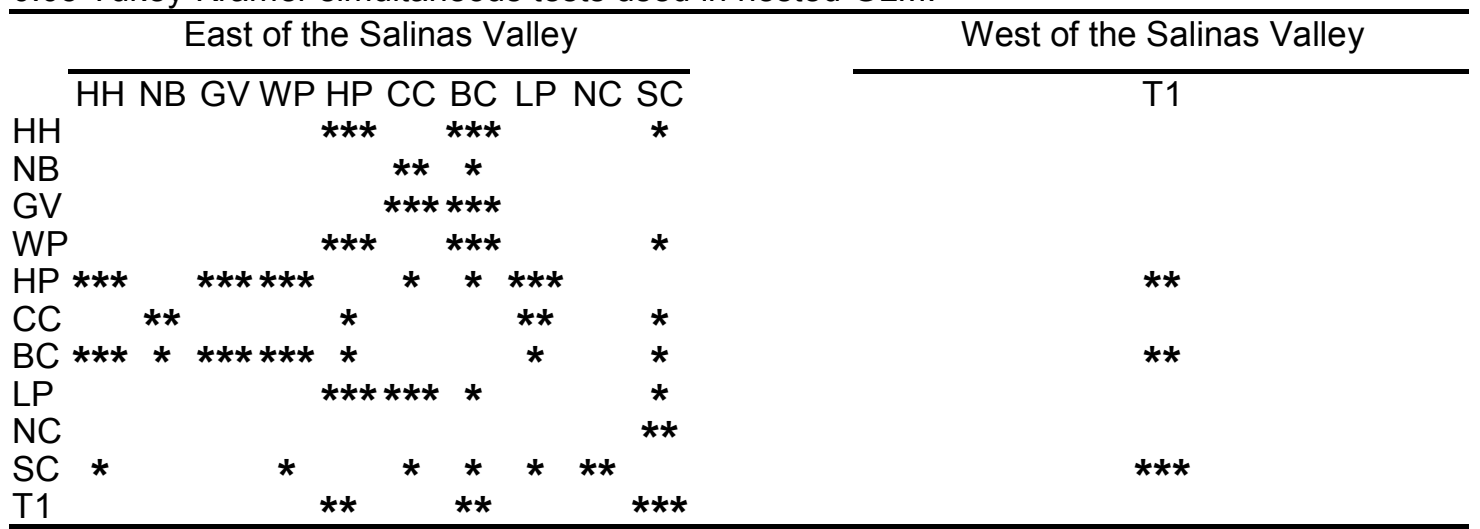

Aspect and plant height were the only two significantly correlated variables $\left(\mathrm{N}=11 ; \mathrm{r}^{2}=0.39 ; \mathrm{P}=0.04 ;\right.$ Fig. 15). Taller plants were found on southwestfacing slopes and shorter plants were found on south to southeast-facing slopes.

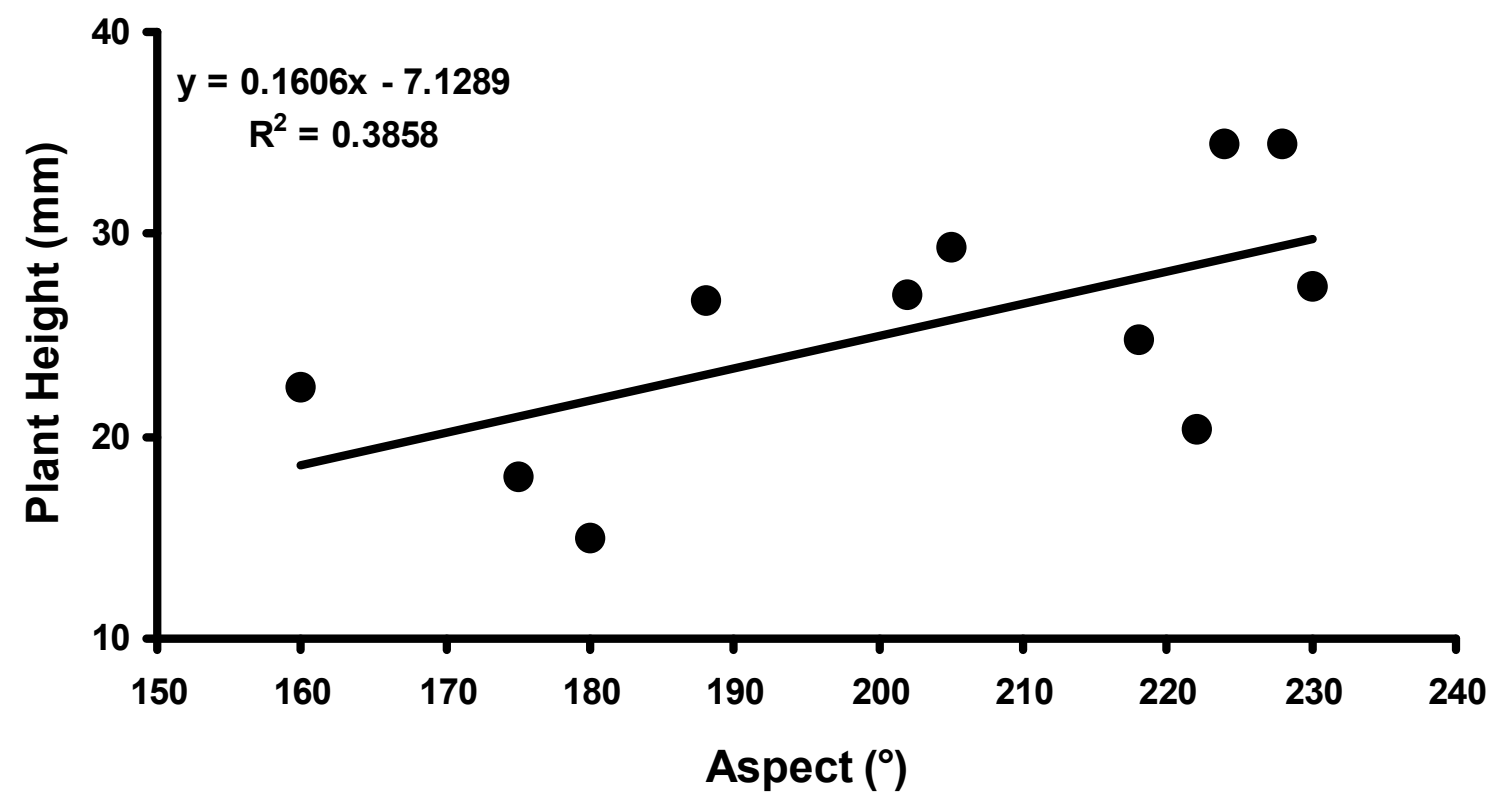

FIG. 15. Relationship between average plant height $(\mathrm{mm})$ and aspect $\left(^{\circ}\right)$ across $E$. nortonii populations. 


\section{Phenology}

Although bloom period was widely variable across space and time, one general pattern emerged (Fig. 16). Palo Corona had no flowers in bloom despite being sampled toward the end of the sampling period. Most individuals had not produced flowering stalks. This phenological pattern may be partially explained by its direct coastal location in the Carmel Highlands, which receives considerable maritime influences.

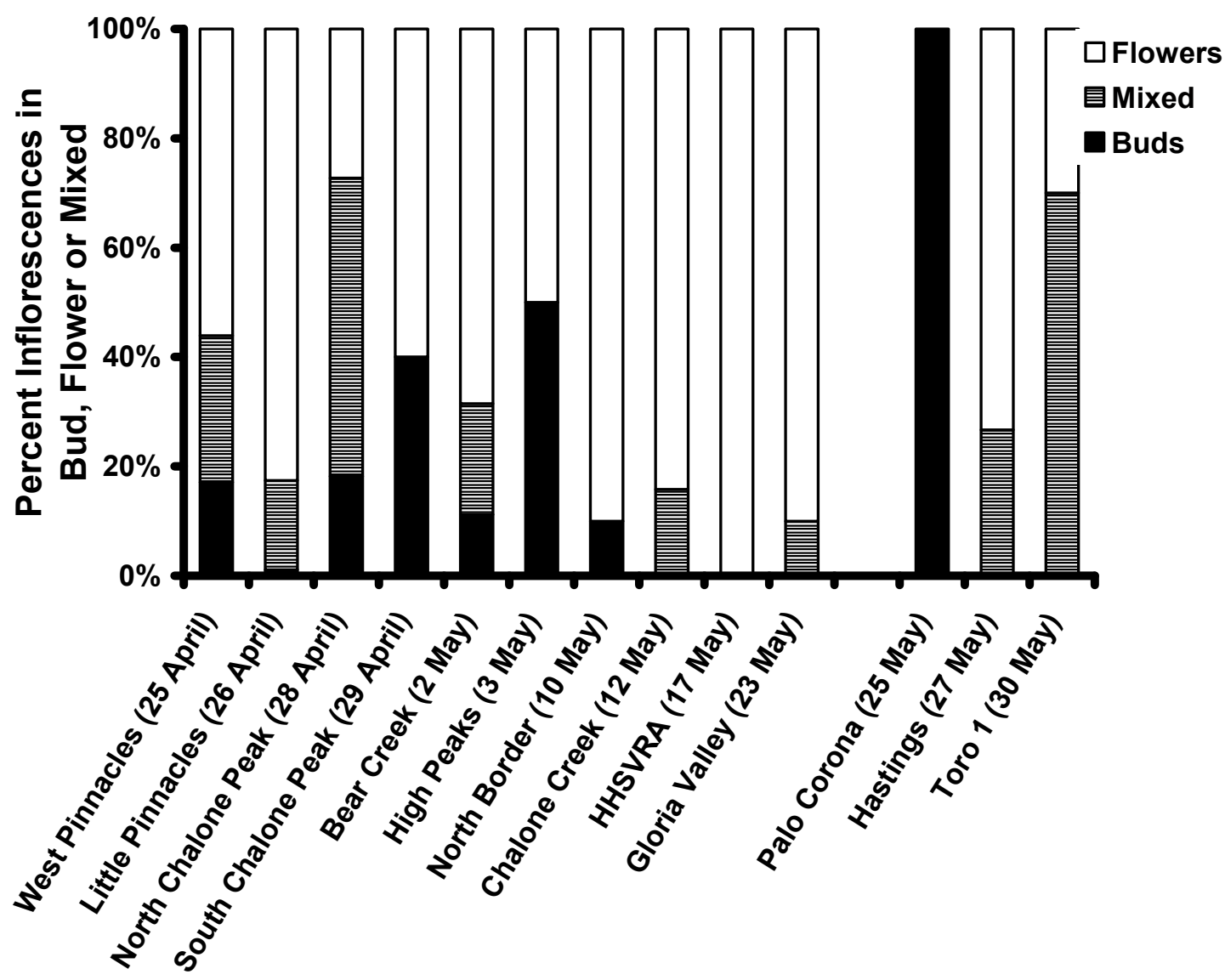

East

\section{Population and Collection Date}

FIG. 16. Percent inflorescences per plant in bud, flower, or mixed phenology across 13 populations aggregated by orientation east or west of the Salinas Valley. Sampling period occurred 25 April 2008 to 30 May 2008. 


\section{DISCUSSION}

\section{Habitat and Morphology}

The rich diversity of Eriogonum species has been attributed to their typically isolated populations, particularly in arid, open habitats. Like other members of the genus, E. nortonii populations demonstrate this general pattern. Eriogonum nortonii populations are often found on southerly aspects where they are more or less positioned within an environment that encourages little competition from surrounding neighbors. Steep, south-facing slopes typically support minimal vegetation composed of species more tolerant of intense sunlight and decreased moisture availability. Higher elevations are generally associated with shallow, nutrient-poor soils. Consequent to those conditions is a sparse, open vegetation structure more favorable to small annuals.

The potential for divergence between $E$. nortonii populations may be influenced by at least two factors. The Salinas Valley acts as a strong barrier to gene flow between inland and more coastal populations of $E$. nortonii. In addition, those same coastal and inland populations also occur in sites with markedly different weather patterns. However, while the most coastal population at Palo Corona showed clear phenological differences, there were no significant differences in morphological characters between E. nortonii populations on opposite sides of the valley.

The late flowering at Palo Corona may result in spatial and temporal differences in plant-pollinator interactions between coastal and inland 
populations. On a spatial scale, E. nortonii populations may be pollinated by different bee species whose individuals likely would not traverse great distances between populations of $E$. nortonii. Differences in spatial and temporal factors influencing pollination across $E$. nortonii populations could potentially influence divergence between populations.

The lack of significant morphological differentiation between populations on opposite sides of the Salinas Valley suggest one of two possibilities: 1) either divergence has occurred, but has gone undetected or 2) divergence has not occurred. The morphological characters measured may not be useful for indicating divergence. Leaf size, plant size, and inflorescence numbers are all plastic characters that may respond readily to local environmental conditions, but may not necessarily be useful for establishing divergence on an evolutionary scale. Because the subgenus Oregonium, of which $E$. nortonii is a member, often relies on minor morphological characters to separate species, the detection of divergence between populations of $E$. nortonii may be difficult to determine from a morphological perspective. Thus, the use of microsatellites may provide resolution at the molecular level.

On the other hand, the results of this study may indicate that divergence has not occurred between populations of E. nortonii on opposite sides of the Salinas Valley. Although this explanation would be unexpected given the barrier to gene flow between E. nortonii populations on opposite sides of the Salinas Valley, it may be that $E$. nortonii has recently speciated and thus has only 
recently dispersed. If the present distribution of $E$. nortonii has only recently been established, then divergence may have not yet occurred.

Factors that may have influenced the recent speciation and range expansion of E. nortonii may be found in paleoenvironmental records. The present climate regime and topography are both relatively recent (between $2 \mathrm{Ma}$ and $10 \mathrm{ka}$ ). The rapid radiation associated with Eriogonum was most likely spurred by the expansion of arid climate that had progressed since the early Tertiary. Early forms were shrubs and perennial herbs while later events resulted in the proliferation of the annual form in Eriogonum. Thus, the speciation of $E$. nortonii may have been the result of recent spikes in aridity $(\sim 8-4 \mathrm{ka})$.

Consequent to climate and landscape changes was the transition of floral elements from mesic woodland to the expansion of xeric, open shrubby habitat such as chaparral. Chaparral supports a different suite of potential dispersal agents from those found in mesic woodlands. Thus, the expansion of chaparral may have led to the concomitant expansion of dispersal agents closely associated with chaparral while the range expansion of potential dispersal agents may have led to the range expansion of $E$. nortonii.

\section{Dispersal}

Seed dispersal has important implications for the exchange of genetic material, range expansion, and persistence of species. Short-distance dispersal events have the potential to result in the endurance of the parent population, 
while long-distance dispersal events may result in the establishment of new populations.

Agents and patterns of short-distance dispersal are often more easily explained while the rarity of long-distance dispersal events makes identification and prediction of likely vectors difficult to pinpoint. Nor may observations of short-distance dispersal processes adequately explain dispersal to greater distances; long-distance dispersal may be due to unusual or multiple vectors or deviation in behavior from a standard vector associated with short-distance dispersal (Higgins et al. 2003; Nathan et al. 2008).

The distribution of $E$. nortonii suggests both long and short-distance dispersal have occurred. Long-distance dispersal may be evident from the separation of populations by the Salinas Valley as well as the species' distribution throughout the length of the Gabilan Range while short-distance dispersal is evident within individual populations. The potential for either long or short distance dispersal may be determined by the diaspore morphology of $E$. nortonii as well as the dispersal mechanisms that operate on E. nortonii.

Diaspore Morphology and Dispersability

Traditional explanations for diaspore dispersal use a morphological-based approach that relates specialized diaspore adaptations to an associated dispersal vector. For example, the plumose pappus of dandelions is thought to be strongly associated with wind dispersal. However, dispersal described within the limited framework of morphology does not consider species without 
specialized dispersal adaptations and, thus, does not adequately account for long-distance dispersal of unspecialized diaspores (Chambers and MacMahon 1994; Tackenberg et al. 2003). In addition, morphological approaches emphasize processes that often move the majority of diaspores short distances, rather than those rare events that move a small number of diaspores long distances (Howe and Smallwood 1982; Van der Pijl 1982; Higgins et al. 2003; Tackenberg et al. 2003). Finally, morphological approaches may not consider important spatial factors such as topography and vegetation or temporal factors such as phenology or availability of a dispersal agent, thus excluding important components from a complete understanding of seed dispersal (Chambers and MacMahon 1994; Tackenberg et al. 2003; Higgins et al. 2003; Levin et al. 2003). Species of arid systems often have achenes with morphologies that inhibit dispersal (Lorts et al. 2008). Small size ( $<2 \mathrm{~mm}$ ) and low mass ( $<3 \mathrm{mg})$, in addition to diaspore geometry, ensure fewer diaspores are dispersed long distances from the parent population. Rounded diaspores are more likely to move vertically into the soil column compared to elongated diaspores that tend to remain on the soil surface (Chambers et al. 1991; Chambers and MacMahon 1994; Lorts et al. 2008).

Strategies that select for seed survival over dispersal in arid environments may carry an advantage. Extremely variable and wide-ranging abiotic conditions in deserts diminish the likelihood of diaspores landing at safe sites similar to the parent population where conditions are expected to be most amenable to 
germination. Species with diaspores that lack morphologies for dispersal may have a greater likelihood of survival nearest the source population, while those that disperse farther are exposed to the unpredictability of the desert environment. Thus, seed without specialized morphologies suggests their long distance dispersal is more serendipitous than directed (Ellner and Shmida 1981; Thompson 1987; Thompson et al. 1993; Willson 1993; Chambers and MacMahon 1994).

Reveal (1969a) suggested the distribution of Eriogonum is due to the lack of an active dispersal mechanism; fruits are generally small and smooth and do not fall far from the parent plant, making range expansion slow at best. Moreover, many extant Eriogonum are found in arid regions. As such, it seems reasonable that the seed of Eriogonum retains traits for optimizing survival within arid systems rather than for long distance dispersal.

The fruit of $E$. nortonii does not appear to have structures commonly associated with a specialized dispersal agent. It is a $1 \mathrm{~mm}$ trigonous achene narrowing to a sharp beak (Fig. 17). The radicle points into the beak and is capable of emergence with the perianth intact (Meyer 2008). Achenes without perianths attached have an average weight of $0.11 \mathrm{mg}$, while those with the perianth attached have an average weight of $0.14 \mathrm{mg}$. Fruit production of E. nortonii is generally abundant with most individual fruits remaining near the parent population after abscission. 


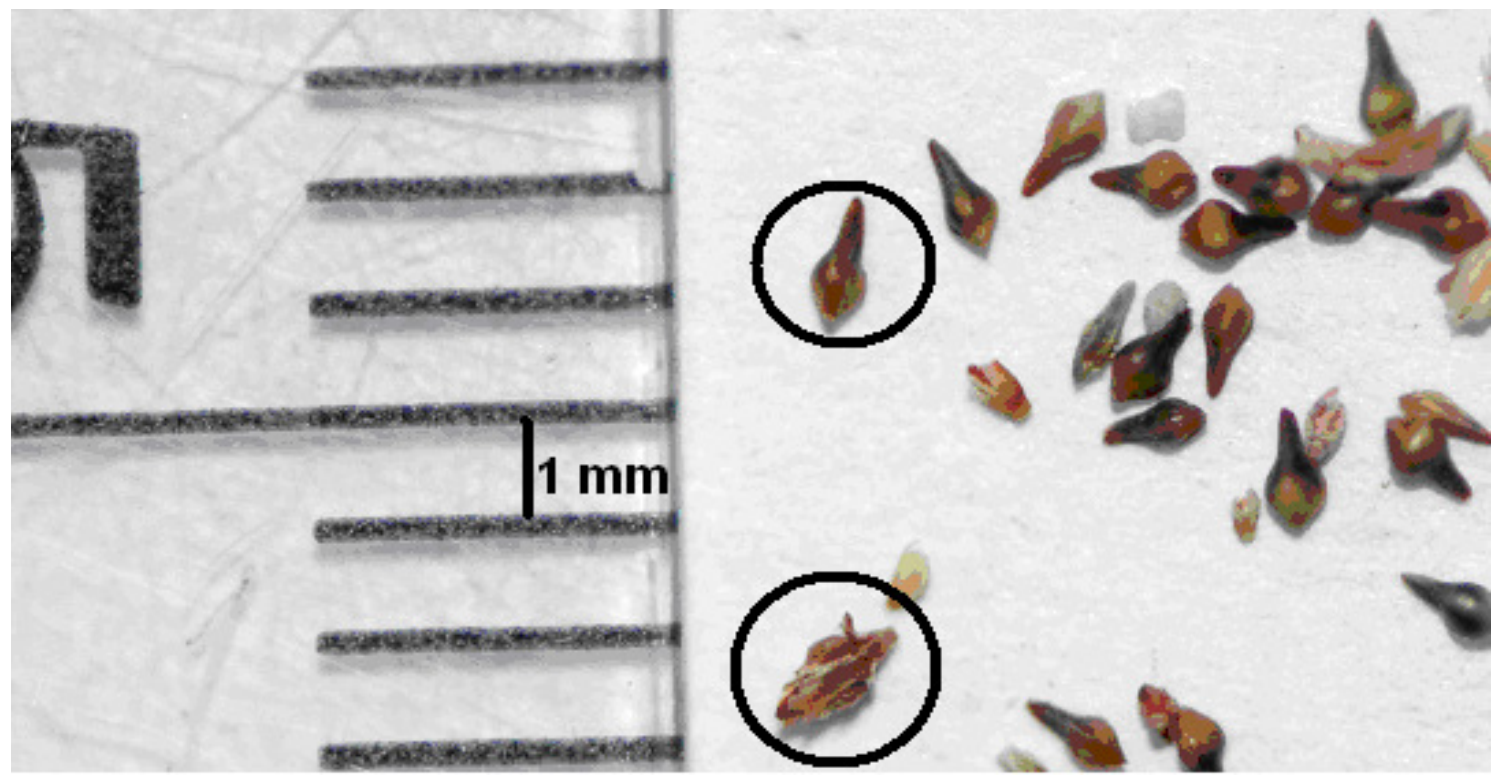

FIG. 17. Eriogonum nortonii achenes without perianth attached (upper circle) and with perianth attached (lower circle).

Eriogonum nortonii fruit may have qualities that could potentially result in either vertical transport into the soil column or horizontal transport across the soil surface. Both the small fruit size $(\sim 1 \mathrm{~mm})$ and beak of $E$. nortonii imply a fruit morphology adapted for particle capture and vertical transport into the substrate. Small fruits become easily trapped by soil particles, while the narrow beak may serve to augment this process by insertion between soil particles.

In addition, because the radicle is located within the beak, capture by soil particles anchors the beak into the substrate with the radicle optimally directed towards nutrients and the water-retaining capacities of the soil. These features may account for the large number of individuals that do not disperse beyond the parent population. If non-dispersal is an established trait of $E$. nortonii, potential colonization of other sites must rely on those individuals that do not become embedded in substrate near the parent population. The elongated shape of $E$. 
nortonii achenes increases the potential for horizontal transport by increasing the chances fruits remain on the surface, available for transport by a variety of dispersal mechanisms. However, while all dispersal agents have the potential to disperse diaspores short distances, they differ markedly in their effectiveness to disperse diaspores long distances (Willson 1993; Chambers and MacMahon 1994; Hughes et al. 1994).

\section{Abiotic-Mediated Dispersal}

Water and wind are both potential abiotic agents for dispersal of $E$. nortonii fruits. Diaspore migration by wind or water in arid systems is most effective in areas free of vegetation and leaf litter, which may otherwise act as impediments to dispersal. Shrub interspaces operate as tunnels that increase wind velocity or as chutes that funnel rain-wash down-slope (Bullock 1976; Ellner and Shmida 1981; Reichman 1984; Chambers et al. 1991; Davies and Sheley 2007; Venable et al. 2008).

Although Eriogonum achenes have been observed floating with the perianth intact (R. Myatt, San José State University, personal communication 2011), long-distance dispersal of $E$. nortonii by water may be unlikely as populations are typically found on slopes far from streams. While this does not negate the possibility of river capture of achenes washed down-slope, the likelihood of captured seeds successfully colonizing new territory along stream banks is extremely small. 
Diaspore dispersal suggests a temporal relationship between the availability of a dispersal agent and timing of fruit abscission. Wind may be ubiquitous in the chaparral environment, particularly at higher elevations, whereas water is only available during the rainy season. As such, wind and granivory may remove a large portion of fruit production before winter rains arrive.

Despite the constancy of wind in open environments, its effectiveness as a long-distance dispersal agent requires a different set of environmental conditions that may be less consistent and predictable than environmental conditions required for short-distance transport. Tackenberg (2003) used a trajectory model in conjunction with field experiments to determine prime conditions for longdistance dispersal $(>100 \mathrm{~m})$. Open landscapes, elevations $>40 \mathrm{~m}$, and steep slopes $\left(>12^{\circ}\right)$ were identified as important topographic parameters that influenced long-distance dispersal while the synchronous occurrence of sunny conditions, high temperatures $\left(>25^{\circ} \mathrm{C}\right)$, low humidity $(<50 \%)$, and low-velocity horizontal winds $(<2 \mathrm{~m} / \mathrm{s})$ were ideal climatic parameters to incur thermal updrafts strongly correlated with long-distance transport, including that of diaspores without specialized dispersal morphologies (Tackenberg 2003; Tackenberg et al. 2003).

Thus, long-distance dispersal of E. nortonii by wind may be seasonally restricted (Nathan et al. 2002; Tackenberg 2003; Tackenberg et al. 2003; Kuparinen et al. 2009) to June through September when high temperatures and 
low humidity coincide with fruit abscission. Wind-rose models in this study suggest the direction of dispersal occurs from the NNW to the SSE. However, the intensity and direction of rare atmospheric disturbances are not apparent in those models. As such, use of these models to predict dispersal events should be taken with caution.

\section{Animal-Mediated Dispersal}

Diaspore dispersal by animals is affected by spatial and temporal variation in diaspore availability, which, in turn, influences the abundance and availability of granivores, including birds, rodents, and harvester ants. Identification of likely granivores for the dispersal of specific taxa is complicated by the preference of many granivores for a wide variety of plant taxa. Thus, dispersal of a single plant species may be performed by multiple granivorous agents (Carroll and Janzen 1973; Mares and Rosenzweig 1978; Chambers and MacMahon 1994; Folgarait and Sala 2002).

Harvester ants, rodents, and birds have been observed foraging for Eriogonum seed. Harvester ants may forage for Eriogonum seed, at times to the exclusion of other species (Tevis 1958; Went et al. 1972; Whitford 1978;

Davidson et al. 1980; Davidson et al. 1985; Kelrick et al. 1986; Fewell and Harrison 1991; Crist and MacMahon 1992; Samson et al. 1992; Gordon 1993) while rodents (Carleton 1966; Bradley 1968; Bradley and Mauer 1971; Went et al. 1972; Meserve 1976; Hallett 1982; Kelt 1988; Samson et al. 1992; Valone and Schutzenhofer 2007) and birds (Glading et al. 1940; Twining 1940; Leopold and 
McCabe 1957; Gullion 1960; Jones 1964; Doerr and Guthery 1983; Barnett and Crawford 1994; Repasky and Schluter 1994) may also utilize Eriogonum seed.

Rodent and Harvester Ant Dispersal. Although, granivory in arid regions is a chief foraging strategy to which rodents (Heteromyidae and Muridae) and harvester ants (Formicidae subfam. Myrmicinae) have become particularly efficient (Davidson 1977a, b; Nelson and Chew 1977; Whitford 1978; Brown et al. 1979; Reichman 1979; Pirk and Casenave 2006; Lengyel et al. 2009), dispersal of $E$. nortonii by rodents and ants may primarily contribute to colonization of locally available open habitat rather than to long distance dispersal events.

Harvester ants are reported to be the dominant dispersal agents within chaparral (Mills and Kummerow 1989) and may contribute to the restricted distribution of E. nortonii where the majority of seed is harvested. Messor Forel and Pogonomyrmex Mayr are the most common granivorous harvester ant genera in chaparral habitat (Linsdale 1945; AntWeb 2011) that rely most heavily on seed (Whitford 1978; Melhop and Scott 1983; Hölldobler and Wilson 1990; Pirk and Casenave 2006; Table 5).

TABLE 5. HARVESTER ANT SPECIES SIGHTED NEAR E. NORTONII SITES AT HASTINGS NATURAL HISTORY RESERVATION AND TORO COUNTY PARK INCLUDING FORAGING STRATEGY AND SEED RELIANCE.

\begin{tabular}{|c|c|c|}
\hline Scientific Name & Foraging Strategy & Seed Reliance $^{c}$ \\
\hline Pheidole californicus ${ }^{a}$ & Column & Occasional \\
\hline Pogonomyrmex subnitidus ${ }^{a}$ & Column & Substantial \\
\hline P. subdentatus ${ }^{\mathrm{b}}$ & Solitary & Substantial \\
\hline Messor andrei ${ }^{\text {a }}$ & Column & Substantial \\
\hline M. stoddardi ${ }^{\mathrm{a}}$ & Solitary & N/A \\
\hline
\end{tabular}

${ }^{a}$ Linsdale 1945; ${ }^{b}$ Antweb 2011; ${ }^{c}$ Hölldobler and Wilson 1990. 
Members of both rodent families Muridae and Heteromyidae are nocturnal, multi-load foragers. However, Murids consume seed when preferred insect resources are limited while Heteromyids are principally granivorous (Eisenberg 1963; Brown et al. 1979; Mares 1993). Murids observed in E. nortonii habitat at Pinnacles National Monument (PNM) and Hastings Natural History Reservation (HNHR) include Peromyscus spp. Gloger and Reithrodontomys megalotis Baird while Heteromyids include Dipodomys spp. Gray, the dominant small mammal at both PNM and HNHR, and Chaetodipus californicus Merriam (Bradford 1976; Fellers 1994, 2006; Heske 1990; Heske et al. 1997; S. Trewhitt, San José State University, personal communication 2011; Table 6).

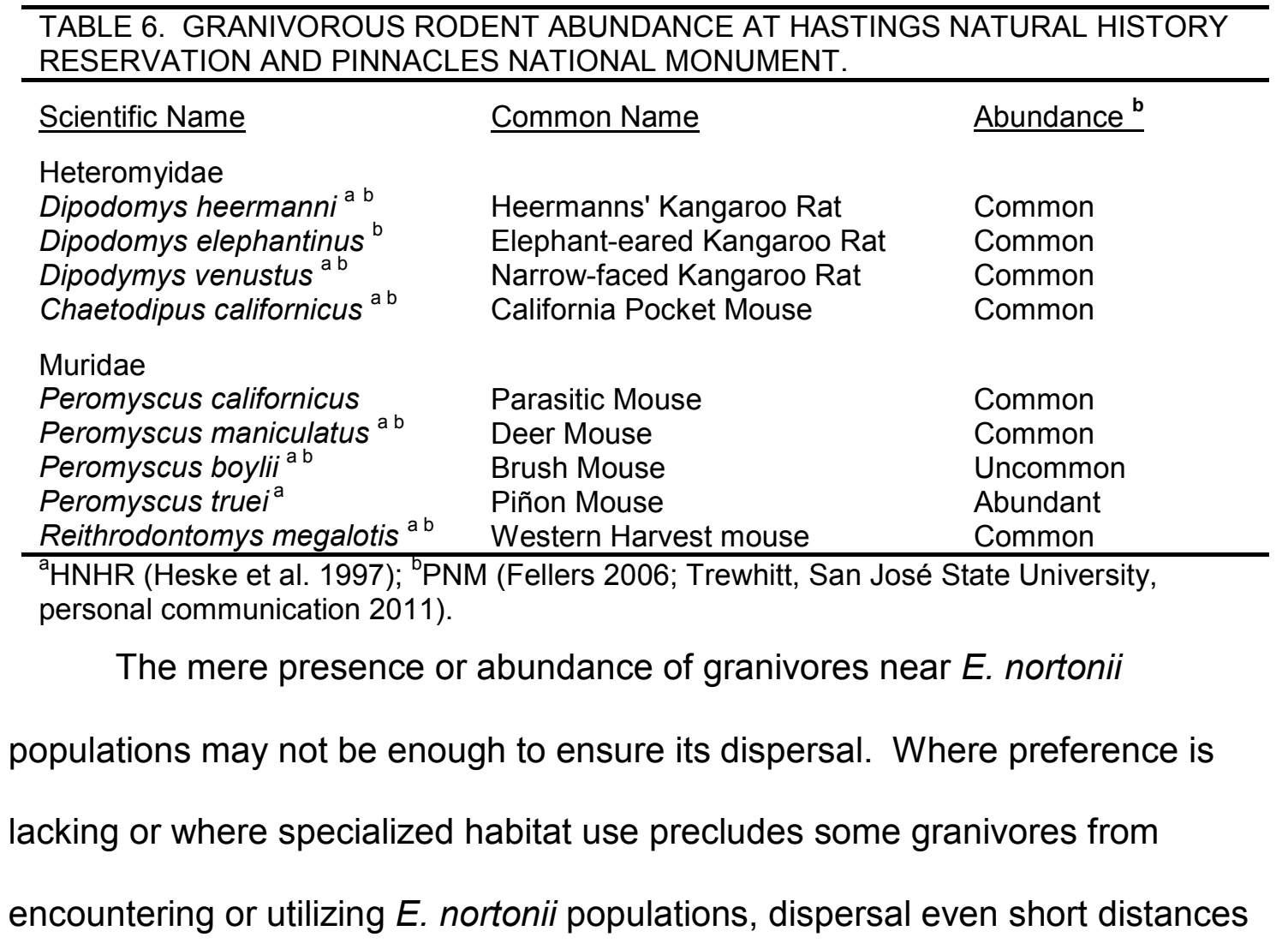


may be minimal at best. Thus, inter- and intra-specific differences in habitat use and foraging behavior, particularly where they intersect with populations of $E$. nortonii, may be useful criteria for pinpointing major contributors to the dispersal of $E$. nortonii.

Numerous variables have been attributed to seed preference by granivores including seed distribution patterns (Davidson 1977b; Reichman and Oberstein 1977; Reichman 1979; Hay and Fuller 1981) and temporal availability of seed (Davidson 1977b; Whitford 1978; M'Closkey 1978). The potential for seed dispersal may be directed, in part, by variable seed densities that attract a variety of both ant and rodent granivores (Reichman 1984). Soil depressions and wind shadows of large rocks act as seed traps that deter movement across the landscape and encourage dense accumulation of seed. Where soil depressions are absent, shrub understories harbor greater seed densities than shrub interspaces (Nelson and Chew 1977; Reichman 1984).

Seed size and shape also affect the likelihood that seed will form dense patches. Small $(<0.25 \mathrm{mg})$, round seed form higher density patches than do large (> $1.76 \mathrm{mg}$ ) or long seed (Reichman 1984).

Harvester ants will preferentially exploit dense patches of seed. However, their capability for doing so is dependent upon colony foraging behavior (Davidson 1977a). Group foraging is most efficient for exploiting clumped seed distributions or resources far from the nest (Davidson 1977a, b; Davidson et al. 1985). Numerous workers decrease time required for locating and transporting 
seed until resources are depleted whereas individual foragers must spend more time locating rather than transporting resources. As such, individual foragers tend to concentrate on scattered resources close to their nest site (Went et al. 1972; Carroll and Janzen 1973). Where resource availability changes from dense to scattered distributions, individual foraging may replace column foraging (Carroll and Janzen 1973).

Like harvester ants, kangaroo rats will selectively forage for dense accumulations of seed over scattered distributions of seed, independent of seed size. Peromyscus species are generally less selective (Brown and Davidson 1977; Reichman and Oberstein 1977; Brown et al. 1979; Reichman 1979; Thompson 1982a; Thompson 1987; Brown et al. 1988).

Further consideration for potential dispersal must be given to spatial and temporal habitat partitioning, especially where partitioning intersects with the availability of E. nortonii seed. Harvester ants, too, partition their environment by use of discrete foraging behaviors determined by resource abundance (Davidson 1977a). The decreased mobility of harvester ants compared to other granivores requires more intense use of resources close to the nest entrance (Davidson 1977a; Reichman 1979; Davidson et al. 1985; Crist and MacMahon 1992) and, thus, spatial awareness of resource distribution within their foraging range.

Sympatric rodents may engage in more complex uses of habitat (Hawbecker 1940; Bradford 1976; Thompson 1982a; Best 1986; Best et al. 1996; Longland and Price 1991). Small, quadrupedal genera such as omnivorous 
Peromyscus may be constrained to foraging within or under shrub canopy, particularly when insect resources are available. Because they frequent shrub cover, they may be more likely to encounter and harvest scattered distributions of seed found in shrub understories.

The bipedality of Heteromyids limits climbing ability and restricts them to open and understory microhabitat (Meserve 1977; Brown and Davidson 1977; Reichman and Oberstein 1977; Smartt 1978; Reichman 1979; Ribble and Samson 1987; Thompson 1987; Mares 1993; Laakkonen 2003). Dipodomys venustus Merriam has been observed in open microhabitat in old agricultural fields and at PNM in sites where it is the sole kangaroo rat species (Hawbecker 1940; Fellers 1994) yet at HNHR it prefers the cover of chamise (Bradford 1976; Heske et al. 1997). The disparate selection of habitat at different sites may be directed by the complex interplay of competition and predation avoidance. For example, large populations of $D$. heermanni Le Conte, also found at both PNM and HNHR, may inhibit co-occupation of sites by other granivorous rodents due to a preference for open areas free of dense herbaceous cover (Kelt 1988).

Seed dispersal is further affected by differences in foraging behaviors and granivore abundances and compositions that reflect temporal availability of resources (Davidson 1977a, b). Seasonal changes in insolation and substrate temperature coincide with peak periods of seed drop in arid regions during late summer. While harvester ants may time peak foraging periods to primary seed drop, their foraging activities are restricted to periods when temperatures are 
tolerable. As a result, common, diurnal foraging activity may shift to crepuscular, nocturnal, or bimodal activity when temperatures are particularly extreme (Tevis 1958; Carroll and Janzen 1973; Brown and Davidson 1977; Davidson 1977a; Whitford 1978; Melhop and Scott 1983; MacKay and MacKay 1989). Among rodents, the typically omnivorous Peromyscus may shift food preferences from insects to seeds in hotter seasons as insect availability diminishes and seed availability increases in (Eisenberg 1963).

Ultimately, granivores that preferentially forage in open habitat where $E$. nortonii is found may be the most likely dispersers of E. nortonii. Harvester ants may be particularly effective short-distance dispersers due to their capacity for modifying foraging patterns based on changes in seed densities and seasonal fluctuations, factors that may influence their role as primary dispersers in chaparral environments (Mills and Kummerow 1989).

However, opportunities for dispersal of $E$. nortonii are likely not uniform across all populations. Inherent differences in micro-topography and vegetation composition that create variable patterns of shrub and seed densities may attract different species compositions of potential dispersers. Preferential utilization of bush microhabitat may result in concentrated use of seed distributed under shrub canopies while species that forage in open microhabitat may be more likely to utilize seed found in shrub interspaces and openings (Brown et al. 1975; Davidson 1977a; Lemen and Rosenzweig 1978; Hallett 1982; Thompson 1982b; Thompson 1987; Brown et al. 1988; Taraborelli et al. 2003). 
Many E. nortonii populations occur over large areas within a system of interconnecting shrub interspaces and wide openings while some populations of E. nortonii cover areas less than $2 \mathrm{~m}^{2}$ and are encircled by dense chamise. Granivores that have a preference for open sites may not visit small, enclosed populations, particularly where shrub boundaries are significantly wide, and potential dispersers that do visit enclosed $E$. nortonii populations may not transport achenes beyond the surrounding vegetation. Even where sufficiently open microhabitat occurs, micro-topography may discourage seed accumulation, resulting in disproportionately more visitations to some $E$. nortonii populations over others by species that selectively forage for high-density clumps of seed.

Bird Dispersal. While birds may not be the primary consumers of seed in arid systems, they are key candidates for long-distance seed dispersal (Pulliam and Brand 1975; Brown et al. 1979). Many plant taxa assumed to be winddispersed over long distances might actually be bird-dispersed (Wilkinson 1997; Higgins et al. 2003).

Dispersal of E. divaricatum Hook., a species common to the American Southwest but discovered in Argentina, was suggested to have occurred by mud stuck to the feet of migratory birds (Reveal 1981). Thus, the disjunct distribution pattern of E. nortonii may be explained by the activity of migratory birds that frequent chaparral on both sides of the Salinas Valley.

The very nature of their high mobility allows birds to utilize habitat at much wider spatial scales than do ants or rodents (Brown et al. 1979). Yet, dispersal of 
E. nortonii may be constrained by such factors as residency status, foraging behaviors, and habitat use (MacArthur and MacArthur 1961; Tomoff 1974; Roth 1976; Avery and Ripper 1989; Milesi et al. 2008). As a result, resource use may be skewed to sites with characteristics that meet the requirements of potential dispersers, thus decreasing the pool of potential dispersers.

Fringillidae (Old World Finches or "finches") and Emberizidae (New World sparrows or "sparrows") are two common granivorous families found in arid regions of North America including chaparral at PNM and HNHR (Table 7). Although other species such as quail (Callipepla californica Shaw) and wrentit (Chamaea fasciata Gambel) do forage for seed, their sedentary natures may exclude them from being key cross-valley dispersers.

In addition, seasonal residency status may constrain foraging to periods that are not synchronous with seasonal seed drop of E. nortonii (Milesi et al. 2008). The residencies of golden (Zonotrichia atricapilla Gmelin) and whitecrowned sparrows (Zonotrichia leucophrys Forster) do not intersect with the dominant period of seed rain making them unlikely dispersers of E. nortonii.

Foraging behavior of birds may limit access to $E$. nortonii seed, particularly if invertebrates account for a greater proportion of their diet (Table 7). Finches ("seed harvesters") typically forage in canopies. Most sparrows are "seed collectors" that mainly forage for seed (Greenlaw 1977; Benkman and Pulliam 1988; Thorngate et al. 2006). 


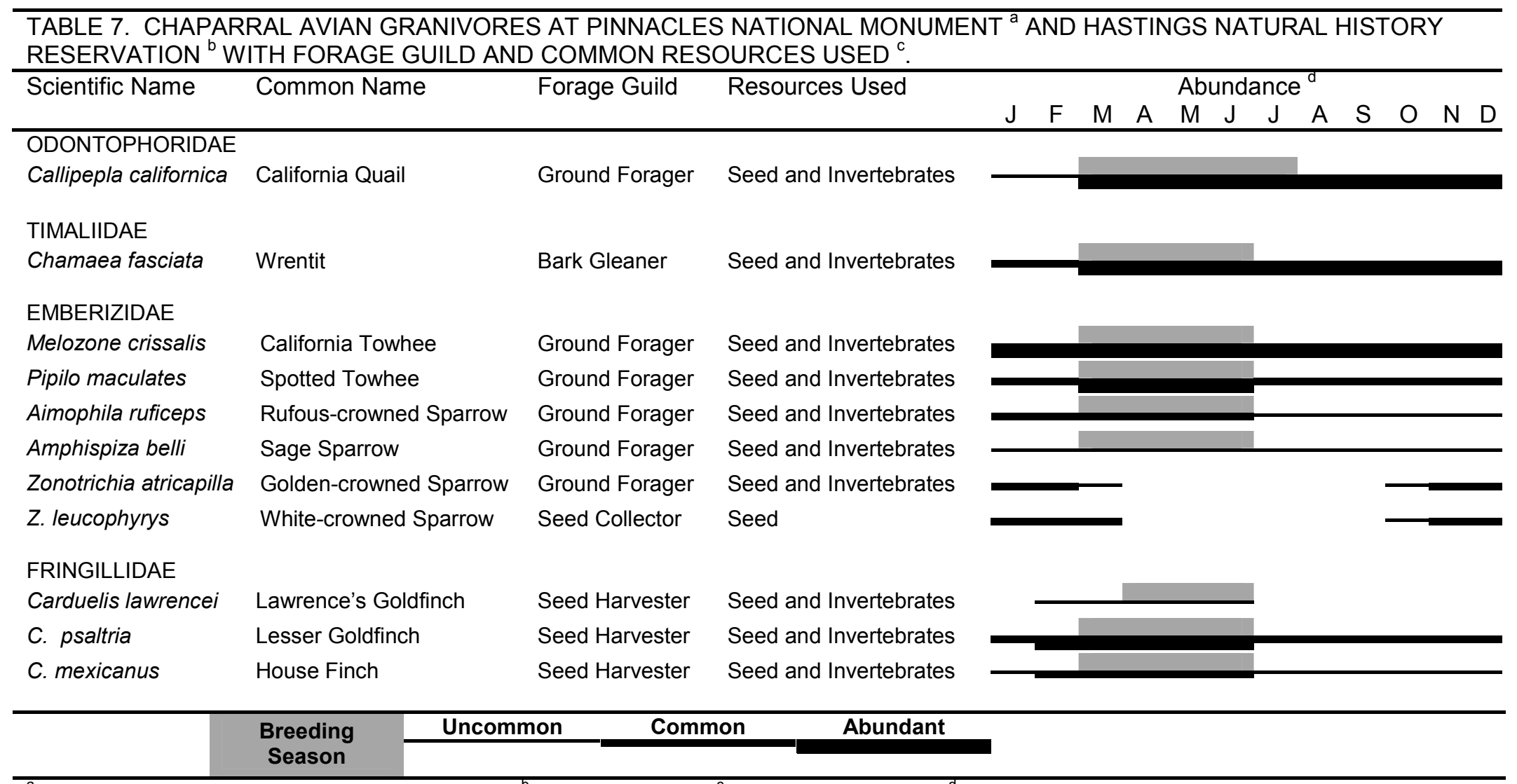

a Emmons 2011; Daniel George pers comm. 2011; ${ }^{\circ}$ Davis et al. 1980; ${ }^{\mathrm{C}}$ Thorngate et al. 2006; ${ }^{\mathrm{d}}$ PNM only 
Similar to rodents, habitat partitioning by birds may preclude some species from being potential dispersers of $E$. nortonii. Finches and some sparrows such as the rufous-crowned sparrow (Aimophila ruficeps Cassin) and spotted towhee (Pipilo maculatus Swainson) may be removed from direct association with ground resources due to their preference for foraging in shrub canopies (Greenlaw 1996; Collins 1999). Other sparrows such as the California towhee (Melozone crissalis Vigors) and sage sparrow (Amphispiza belli Cassin) prefer to forage on open ground (Martin and Carlson 1998; Benedict et al. 2011). However, for both sparrows and finches, particularly exposed areas may be avoided where the availability of nearby cover is limited (Pulliam and Mills 1977; Milesi et al. 2008).

Both finches and sparrows may further partition resources by seed size. Sparrows generally consume smaller seeds $(<2 \mathrm{mg})$ and have a narrower range of seed sizes they can efficiently handle. Because smaller seeds provide lower energetic reward, sparrows are required to expend more "sedentary" time foraging in individual sites (Benkman and Pulliam 1988).

In contrast, the stronger jaw muscles of finches allow them to exploit a larger and wider range of seed sizes. Moreover, finches have mouth and gut storage structures that allow them to hoard seed and, thus, relieve necessity for continual foraging (Benkman and Pulliam 1988). 


\section{Seed Fate}

Even where seed densities and site parameters invite potential dispersal of $E$. nortonii achenes, seed survival and dispersal is restricted by the handling and digestive processes of potential dispersers. Ultimately, active seed predation is more likely to result in seed mortality than in successful dispersal of intact seed (Tiffney 2004).

Handling and consumption, particularly by ants and rodents, results in mortality for the majority of seed (Krefting and Roe 1949; Hughes et al. 1994). Seed may only escape predation if viable seed is mistakenly disposed on refuse piles, dropped in transport, or enters the soil column undetected.

Likewise, few seed generally survive the handling and digestive processes of birds (Holbrook and Loiselle 2007). Granivorous birds handle seed either by swallowing whole (e.g. doves) or by husking (e.g. finches) (Hrabar and Perrin 2002). However, the guts of huskers do not require heavy, grinding stomachs to process hard seed coats since husked seed is already partially broken down prior to digestion (Murphy et al. 1993). Thus, a few seed may be evacuated undamaged (Coates-Estrada and Estrada 1988; Lambert 1989).

The length of time seed remains in the gut varies by species (Herrera 1984; Schupp 1993), suggesting that gut retention times are associated with dispersal distance and that those species that retain viable seed longer are more likely to distribute $E$. nortonii further from the source population. For example, the storage structures that allow finches to spend less time foraging also allow 
them to spend more time in flight, potentially covering wider spatial scales than sparrows (Benkman and Pulliam 1988).

Shared associates across several E. nortonii sites suggest some sites receive the same species of long-distance dispersers. For example, Chorizanthe is found in many E. nortonii populations on both sides of the Salinas Valley. All E. nortonii populations studied west of the Salinas Valley were associated with Chorizanthe while three populations studied east of the Salinas Valley were associated with Chorizanthe. Although shared associates across populations may be due to any number of factors, where bird-dispersed seed occurs, some mixtures of seed and, thus, population associates may not be due to chance alone (Jordano 1988; Loiselle 1990). Those sites E. nortonii shares with preferred associates may receive preferential visitation over $E$. nortonii sites without a preferred associate. Ultimately, E. nortonii seed from sites with preferred associates may have a greater chance for dispersal long distances than seed from sites without preferred associates.

\section{Dispersal Summary}

The absence of E. nortonii populations beyond its present distribution may not be due to a lack of habitat. Chaparral is ubiquitous outside of its present range. Presumably the same species of birds that occupy chaparral within the range of $E$. nortonii also occupy chaparral outside the range of $E$. nortonii. As such, the potential for long-distance seed transport should be roughly equivalent in all directions. Otherwise, the restricted distribution of $E$. nortonii suggests a 
rarity of movement across the Salinas Valley by the majority of potential dispersers while the apparent non-dispersal strategy of $E$. nortonii seed suggests the majority of seed production does not travel far from the parent population. The ingestion of $E$. nortonii fruits is dependent upon the rare intersection of habitat and resource requirements and assemblages of likely dispersers while the successful long distance colonization by $E$. nortonii requires survival of the digestive processes of potential long-distance dispersers, all of which indicates long distance dispersal of $E$. nortonii seed may proceed by extremely rare events that contribute to its restricted distribution.

\section{Paleoenvironment of Early Eriogonum Species}

The close association of Eriogonums with arid environments suggests southerly origins while pollen samples place the earliest presence of Eriogonum in grassland and steppe environments $\sim 8 \mathrm{Ma}$ on the Columbia Plateau of southeast Washington and $\sim 16 \mathrm{Ma}$ in the Rocky Mountain foothills of eastern Wyoming (Leopold and Denton 1987).

Reveal (1969a) suggested basal Eriogonums were shrub or sub-shrubs that occupied exposed, low slopes within the arid piñon-juniper woodlands of the southern Rocky Mountain Range and northern Mexico while more derived taxa speciated in chaparral of the California Coast Ranges (Reveal 1978). Surrounding communities included mesic woodlands comprised of deciduous hardwood species with Asian and eastern North American associations, subtropical broad-leaved evergreens, and xeric shrublands that were expanding 
in response to increasing aridity, cool temperatures, and seasonality (Axelrod 1950; Graham 1999; Zachos et al. 2001).

Aridity, in particular, is thought to have influenced the rapid diversification of Eriogonum (Raven 1973; Sanchez and Kron 2008). Diverse sources of aridity may co-occur where soil, topographic, and climatic factors intersect and act cumulatively or independently resulting in an aridity gradient to which local taxa adapt and diversify.

Edaphic aridity has been a selective force on angiosperm evolution since at least the Cretaceous despite a prevailing, equable macroclimate (Axelrod 1972). Barren sites of exposed basement rock are nutrient-poor and highly porous, shed rain-wash quickly, and invite little competition from mesic-adapted taxa. Thus, xeric-adapted taxa may have persisted on barren patches that otherwise inhibited colonization (Callaway and Davis 1993). Also, the isolation of exposed basement during periods of warm, humid climate may have further enforced conditions for speciation on sites where edaphic islands were isolated by surrounding mesic taxa, thus favoring speciation of xeric taxa (Stebbins 1952).

Rain shadows formed from ongoing tectonic processes, as well as an increasingly dry and seasonal climate trend, amplified the dry conditions of basement exposures (Axelrod 1972). Consequently, the co-occurrence of three prominent sources of aridity (soil, topography, and climate) may have accelerated speciation in genera such as Eriogonum where plants were exposed 
to arid conditions.

Aridity may have also indirectly contributed to the range expansion of Eriogonum. Expanding dry climate led to the elimination of mesic-adapted taxa through extinctions and the extirpation of species intolerant of dry environments (Chaney 1947), thus creating openings where extant species could colonize and diversify. Islands of drought-adapted flora that had persisted from more mesic periods expanded as elimination of woody taxa left open and increasingly unified tracts of colonizable habitat (Axelrod and Raven 1985).

Salinas Valley and Central Coast Ranges Paleoenvironment Miocene (23 - $5 \mathrm{Ma})$. Major modern topographic features of the northern and central Salinas Valley, now offset by $315 \mathrm{~km}$ along the San Andreas Fault (SAF), were adjacent to the northwestern border of the Mojave Desert in the early Miocene (23 - 16 Ma; Graham et al. 1989; Powell 1993; Sims 1993; Dickinson and Wernicke 1997; Barth et al. 2003; Dickinson et al. 2005; McQuarrie and Wernicke 2005; Fig. 18). The Gabilan Range, at the junction of the San Emigdio Mountains and the SAF, possibly formed a continuous highland with the Ben Lomond region of the Santa Cruz Mountains (Graham et al. 1989) while the Sierra de Salinas was more proximal to the southern end of the Gabilan Range prior to late Miocene faulting in the Salinas Valley region (Rosenberg and Clark 2009).

Regional volcanism also influenced the early Miocene Salinas Valley environment (Dickinson 1997; Stanley et al. 2000). The Pinnacles Volcanic 
Formation (PVF) west of the SAF in the Pinnacles National Monument and the Neenach Volcanic Formation (NVF) east of the SAF near Lancaster, California, together comprise the remnants of an ancient eruption that crossed fault boundaries along the northwest border of the Mojave region approximately 24 22 Ma (Turner et al. 1970; Matthews 1976; Sims 1993). The Pinnacles-Neenach Volcanics emerged from a topographic high, but marine fossils in the rhyolite breccia stratum suggest at least partial deposition into a marine environment (Matthews 1976).

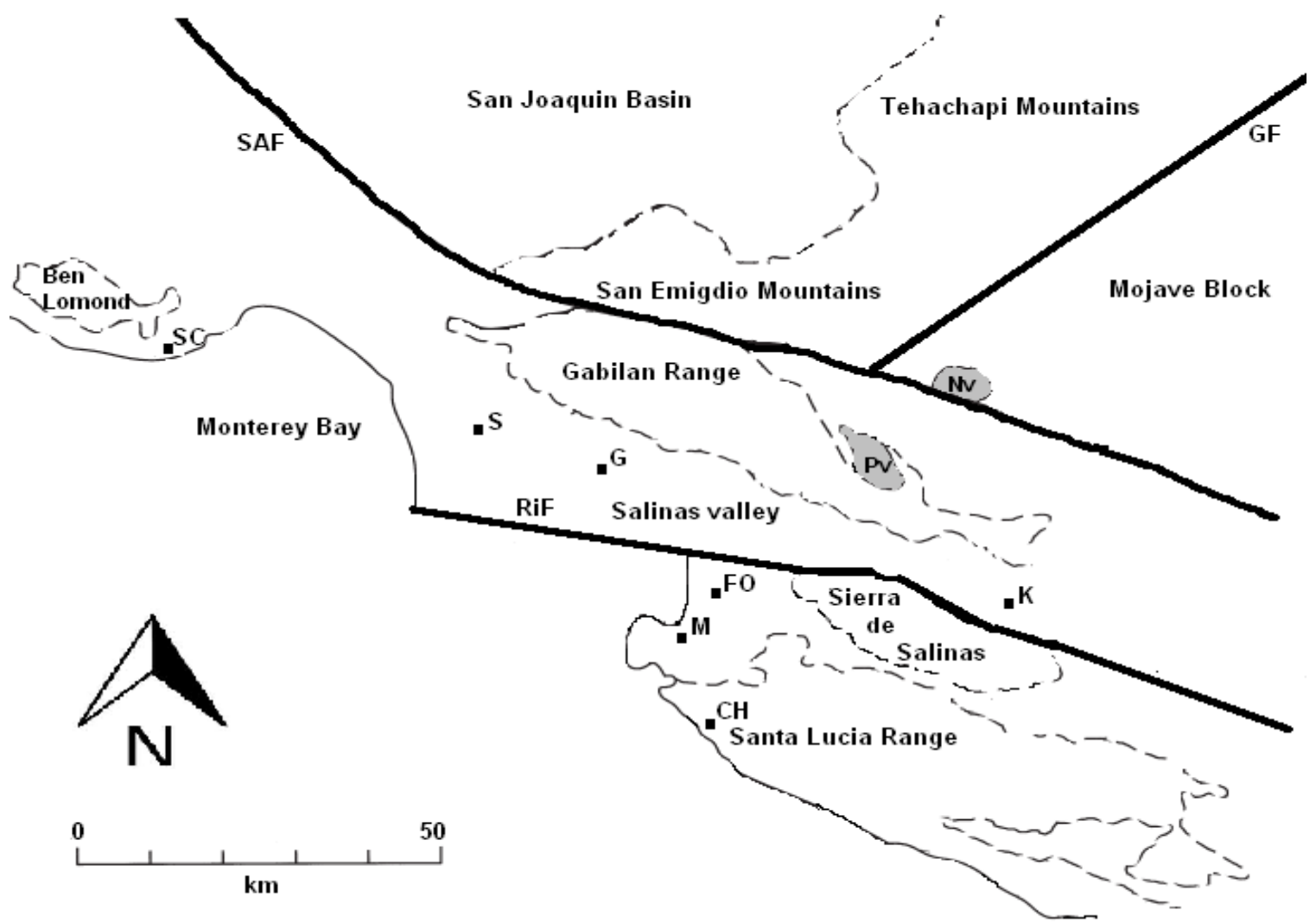

FIG. 18. Approximate Miocene restoration of the northern Salinas Valley prior to dextral slip on the San Andreas and Rinconada faults (modified from Hall 2002 and Dickinson et al. 2005). $\mathrm{CH}=$ Carmel Highlands; FO = Fort Ord; $\mathbf{G}=$ Gonzales; $\mathrm{GF}=$ Garlock fault; $\mathrm{K}=$ King City; $M$ = Monterey; S = Salinas; SC = Santa Cruz; Nv = Neenach Volcanics; Pv = Pinnacles Volcanics; RiF = Rinconada fault; SAF = San Andreas fault. 
Along the coast, marine waters covered Fort Ord, the northern and southern Sierra de Salinas, the northern Santa Lucia Range (Clark et al. 1974; Dupré 1990; Clark et al. 2000), the Carmel Highlands (Clark et al. 1974), the base of the Pinnacles area (Wagner et al. 2002), the northern Gabilan Range (Gribi 1967; Clark and Reitman 1973), and the San Joaquin Basin (Hall 2002). Although marine transgressions along the central coast and into the interior southern Central Valley were widespread from the middle to late Miocene (16 $-5 \mathrm{Ma})$, emergent land is suggested by ancient remnant Tertiary erosion surfaces (Snetsinger 1962; Dohrenwend 1975; Page et al. 1998; E. Taylor, USGS, personal communication). Terrace gravels near Junipero Serra Peak in the northern Santa Lucia Range are presently found at $1100 \mathrm{~m}$ (Snetsinger 1962), while the average ridgecrest elevation is approximately $1700 \mathrm{~m}$ (Tinsley 1975), which suggests pre-uplift elevations, not considering erosion rates, were closer to $600 \mathrm{~m}$.

Tinsley (1975) suggested the Gabilan Range, with its topography of low, broad connected ridges that average $900-1000 \mathrm{~m}$, represents an erosion surface that has not undergone the extensive faulting and folding of the Santa Lucia Range. Instead, it has remained a relatively rigid block where recent uplift is indicated by steep valleys and v-shaped canyons at its margins. Gloria Valley, where an E. nortonii population was located, is a broad, upland valley that may have been an erosion terrain prior to Quaternary uplift. 
Between 17 - 15 Ma the Gabilan Range detached from the Neenach segment and was transported approximately $95 \mathrm{~km}$ northwest along the SAF (Powell 1993; Sims 1993; Nicholson et al. 1994; Dickinson 1996; Dickinson and Wernicke 1997; Page et al. 1998; Dickinson et al. 2005; McQuarrie and Wernicke 2005). While in the vicinity of the Temblor Range, the Gabilan Range is suggested to have been the source for granitic and volcanic conglomerate deposits in the marine Santa Margarita Formation between 11-6 Ma (Huffman 1972; Ryder and Thomson 1989).

Miocene paleofloras in Central and Southern California suggest diverse assemblages of genera common to contemporary floras with genera now considered exotic to the California and desert floristic provinces. Deciduous hardwood species with Asian and eastern U.S. affinities occurred with subtropical broadleaved evergreens and sclerophyllous xeric taxa now associated with the American Southwest, Mexico, and South America (Condit 1938; Axelrod 1939,1944a, 1980, 2000; Renney 1972; Raven and Axelrod 1978). The occurrence of species now found in more tropical and subtropical environments suggests the floras were acclimated to a summer-rain, warm-winter climatic regime controlled, in part, by inland seas.

Reconstruction of a proto-northern Salinas Valley (the area encompassing all of the Gabilan Range and the northern Sierra de Salinas and Santa Lucia Ranges to King City) paleoflora requires evaluation of nearby paleofloras prior to and after initiation of right-lateral displacement on the SAF. The most plausible 
genera found in the Miocene Salinas Valley region may have been from paleofloras temporally and geographically nearest the Salinas Valley as it moved northwest along the SAF in addition to shared genera between paleo and present floras found in the Salinas Valley and surrounding ranges (Fig. 19).

The deposition site of the species-rich Tehachapi flora (17 -16 Ma) on the leeward flank of the Tehachapi Range, east of the SAF in the western Mojave Desert, is presently about $60 \mathrm{~km}$ from the Neenach Volcanics. However, past sinistral slip along the Garlock Fault suggests that the deposition site was originally about $72 \mathrm{~km}$ from the Neenach Volcanics (Powell 1993). Many genera of the Tehachapi flora are still found in the Mojave and Sonoran Deserts (Axelrod 1939). Although the western regions of the northern Salinas Valley likely supported more mesic flora during the Miocene, the eastern Gabilan Range may have created enough of a rain shadow where xeric species associated with the Tehachapi flora were found.

The mesic regions of the northern Salinas Valley during the Tertiary may have more closely resembled the microfossil (pollen) assemblages of the Wilmington (13.5 - 3 Ma; Martin and Gray 1962), Site 467 (15 Ma - 2 Ma; Ballog and Malloy 1981), and Lion's Head (14 - 10 Ma; Srivastava 1984) microfloras, which suggest Quercus, Pinus, Juniperus, Cupressus, Carya, Castanea, Juglans, and members of Ericaceae were particularly widespread in coastal southern California during the Miocene. 


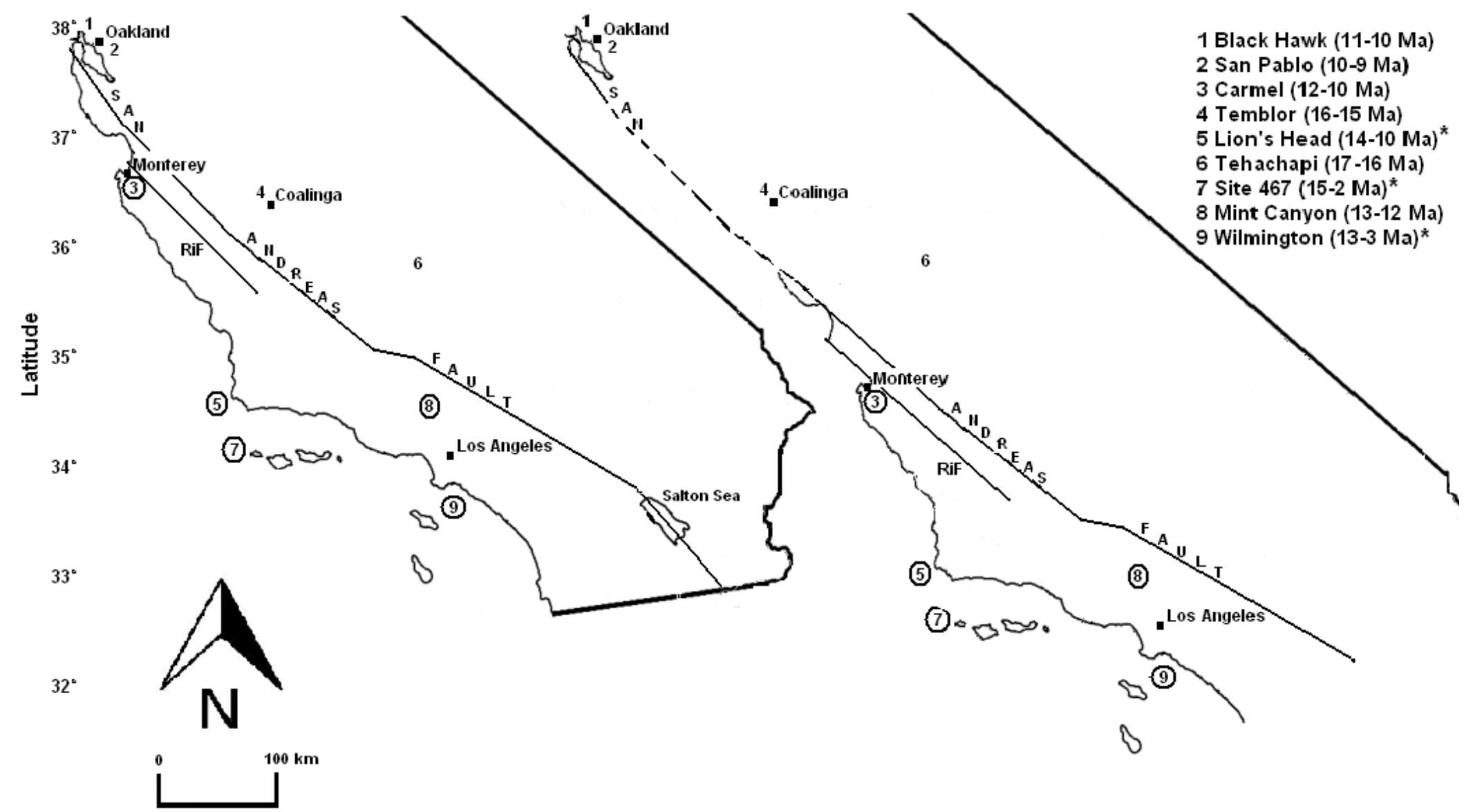

FIG. 19. Miocene macro and microfossil $\left(^{*}\right)$ paleoflora locations. Left figure represents present locations of paleofloras; right figure represents locations at time of deposition. Circled floras have shifted up to $315 \mathrm{~km}$ northwest along the San Andreas fault. Latitudes are approximate. Locations of floras based on Condit 1938; Axelrod 1939, 1944a, 2000; Martin and Gray 1962; Renney 1972; Ballog and Malloy 1981; Srivastava 1984. 
Rich and Pirkle (1994) proposed that sedimentation studies on the southeast coast of North America suggest Carya, Quercus, and Pinus pollens are indicative of coastal marine environments. This is supported by the Temblor flora (16 - 15 Ma; Renney 1972), deposited $230 \mathrm{~km}$ from the Salinas Valley region on the western border of the San Joaquin Sea and the Carmel flora (12 $10 \mathrm{Ma}$; Axelrod 2000) deposited west of the southern Gabilan Range within the present day Carmel River Valley. In addition to pine and oak, the Temblor flora also includes Carya and Castanea while the Carmel flora, comparable to contemporary tropical cloud forests of the Sierra Madre of central Mexico, may have allowed a broadleaf evergreen lauraceous element (Bucida, Nectandra, Ocotea) to persist due to coastal fog (Renney 1972; Axelrod 2000).

The Mint Canyon flora to the south (13-12 Ma; Axelrod 1940) and the Blackhawk (11 - 10 Ma; Axelrod 1944a) and San Pablo (10 - 9 Ma; Condit 1938) floras in the San Francisco Bay Area ( 400 km from the northern Salinas Valley region) confirm the widespread occurrence of shared genera and, therefore, increase the likelihood that those genera were also present in the Miocene northern Salinas Valley. Thus, the northern Salinas Valley flora of the Tertiary may have had a number of recognizable elements with a few species now considered to be exotics, many of which were likely segregated by the prevailing topography (Table 8). 
TABLE 8. POSSIBLE GENERA IN THE NORTHERN SALINAS VALLEY 17 MA -

QUATERNARY. Based on Chaney and Mason 1930, 1933; Mason 1934; Condit 1938;

Axelrod 1939, 1940, 1944a, b, c, 2000; Martin and Gray 1962; Langenheim and Durham 1963; Axelrod 1966, 1983; Helley et al. 1972; Renney 1972; Adam et al. 1979; Ballog and Malloy 1981; Srivastava 1984.

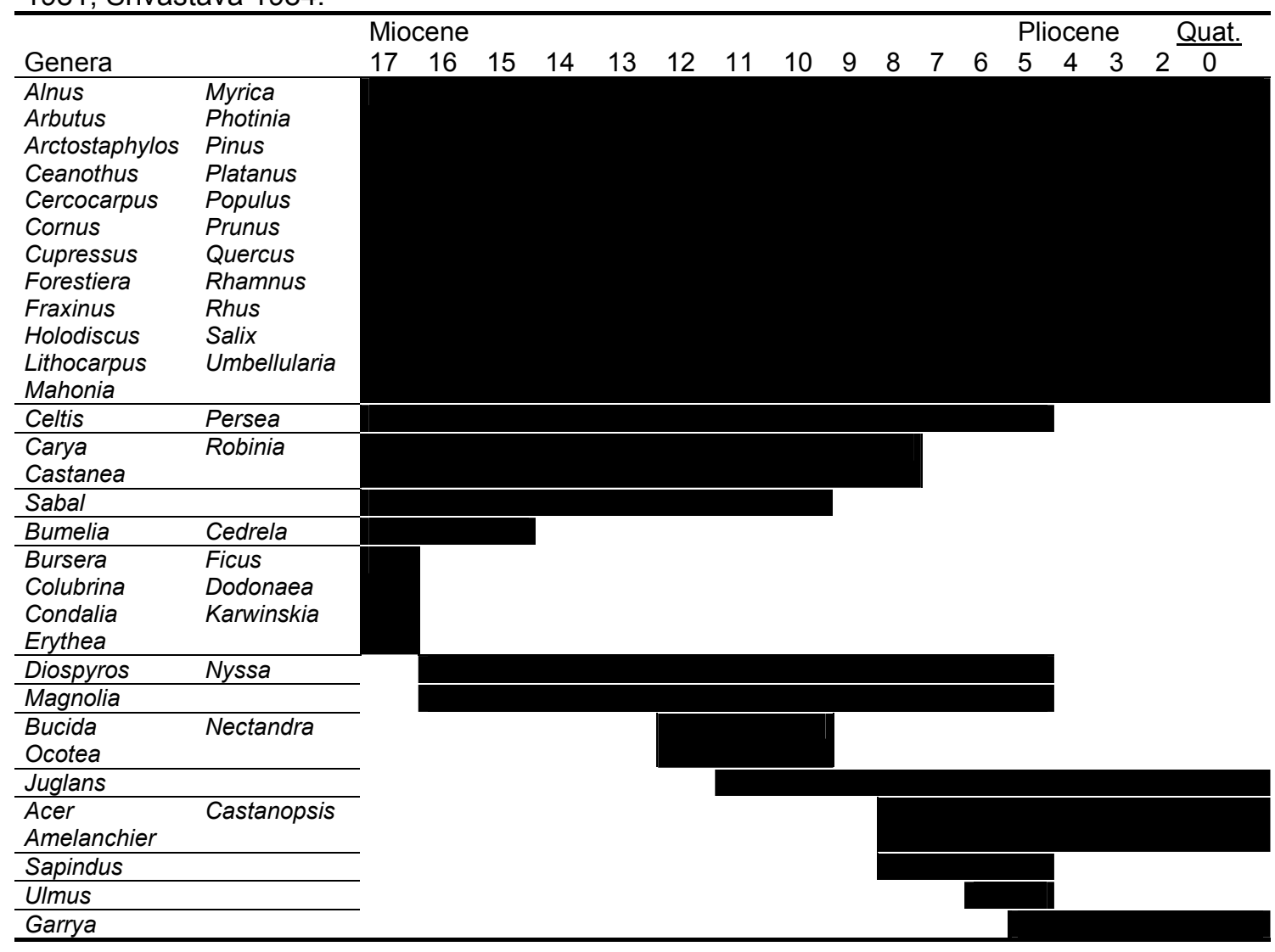

Dry, south-facing slopes with shallow soils such as the volcanic rock of

Pinnacles or soils of crystalline basement material may have supported genera

now associated with desert scrub such as Colubrina, Condalia, Dodonaea,

Forestiera, and Karwinskia. It is probable that the eastern flank and ridge tops of

the Gabilan Range supported desert-associated genera, while genera such as

Arbutus, Cupressus, Myrica, Quercus, Persea, Pinus, and Umbellularia formed

woodland-savannahs on north-facing slopes and in valleys with deeper soils, 
particularly on the western flank of the Gabilan Range as well as towards the more mesic Sierra de Salinas and Santa Lucia Ranges.

Arctostaphylos, Ceanothus, Cercocarpus, Holodiscus, Mahonia, Photinia (Heteromeles), Quercus (scrub), Prunus, Rhamnus, and Rhus, now recognized as common contemporary chaparral components, likely occurred as woodland understory during the Miocene, but may have mixed with desert scrub taxa where conditions permitted. Sabal and Erythea, common palm genera, may have transitioned between upslope and riparian woodlands where Platanus, Populus, and Salix were more dominant (Axelrod 1939). Bucida, Nectandra, and Ocotea as well as closed-cone conifer/oak woodlands may have been widespread where cool, coastal conditions prevailed including the northern Sierra de Salinas, Santa Lucia, and Gabilan Ranges.

Late Miocene to early Pliocene $(\sim 8-5 \mathrm{Ma})$ displacement along the Rinconada Fault shifted the Santa Lucia and Sierra de Salinas Ranges further northwest $20 \mathrm{~km}$ (Rosenberg and Clark 2009). The occurrence of Magnolia, Persea, and Sapindus in the Central Valley paleofloras suggests the inner Coast Ranges in that area were at elevations low enough to allow for maritime influences from the west while southern and northern California paleofloras of the same period indicate continued generic segregation (Axelrod 1934, 1944b, c, 1950, 1980).

Genera now considered exotic were extirpated from the central coast region by the middle Pliocene while the contemporary woody flora in California 
was essentially established by the driest part of the Tertiary, late Pliocene, including widespread expansion of chaparral taxa (Axelrod 1989). These changes may have been reflected on the drier ridges and south-facing slopes of the northern Salinas Valley.

Late Pliocene - Pleistocene (5 Ma-20,000 ka). With the onset of Pleistocene glaciations, the climate had changed from arid and warm to cool and humid, resulting in changes to local vegetation (Chaney and Mason 1930, 1933; Potbury 1932; Mason 1934; Axelrod 1966, 1980; Adam et al. 1979; Axelrod and Hill 1988; Axelrod and Govean 1996). The Salinas Valley region reached its present position along the SAF by the Pleistocene ( $2 \mathrm{Ma}-12 \mathrm{ka}$ ) while the western half of the Salinas Valley shifted another $18 \mathrm{~km}$ northwest into its present position on the Rinconada Fault Zone (Rosenberg and Clark 2009).

At $\sim 3.5 \mathrm{Ma}$ the central Coast Range orogeny ensued; accelerated folding and thrusting occurred post - $2 \mathrm{Ma}$ and as late as $400 \mathrm{ka}$ (Christensen 1965; Page et al. 1998; Ducea et al. 2003). Christensen (1965) suggests average uplift between 250 - $1000 \mathrm{~m}$ post-Pliocene throughout the central Coast Ranges. Early Pleistocene uplift in the Gabilan Range occurred to 500 m (Baldwin 1963; Dohrenwend 1975, 1979), while uplift in the Santa Lucia Range occurred to about 1000 m (Snetsinger 1962; Compton 1966; Howard 1973). Activity on the Reliz fault, adjacent to the northeastern boundary of the Sierra de Salinas, resulted in vertical displacement of the Sierra de Salinas to $3000 \mathrm{~m}$ (Dibblee 1976). Present elevations reach to $1360 \mathrm{~m}$. 
Early Quaternary uplift in the central Coast Ranges lead to eventual sequestration of the San Joaquin inland sea (Bowersox 2005; Powell et al. 2007), recession of marine waters and widespread erosion of $1-5 \mathrm{~km}$ of rock in the central Coast Ranges (Page et al. 1998). Low Pleistocene sea levels resulted in incision of valley fill by the Salinas River while interglacial periods resulted in the submersion of the northern Salinas Valley that may have extended up to Gonzales (Tinsley 1975).

There are few inland fossil floras from the Pleistocene. Coastal fossil floras suggest closed-cone conifer woodlands had wider Pleistocene distributions along the coastal strip than present populations (Fig. 20). For example, the Carpinteria flora (39-40 ka) in southern California supported taxa contemporary to the closed-cone forests that now occur on the Monterey Peninsula including Ceanothus thyrsiflorus, Cupressus goveniana, Garrya elliptica, Juniperus californica, Myrica californica, Pinus muricata, P. radiata, P. remorata, $P$. sabiniana, Quercus agrifolia, Toxicodendron diversilobum, and Umbellularia californica (Chaney and Mason 1933).

Closed-cone woodlands of the Pleistocene were limited by the same parameters that limit contemporary closed cone woodlands including high temperatures, low fog cover, and low precipitation. Sites such as where the Seacliff flora was deposited are now surrounded by coastal sage scrub indicating that temperatures are approximately $1.5^{\circ} \mathrm{C}$ higher and annual precipitation is approximately $41-65 \mathrm{~cm}$ lower than in the Pleistocene (Axelrod 1983). 


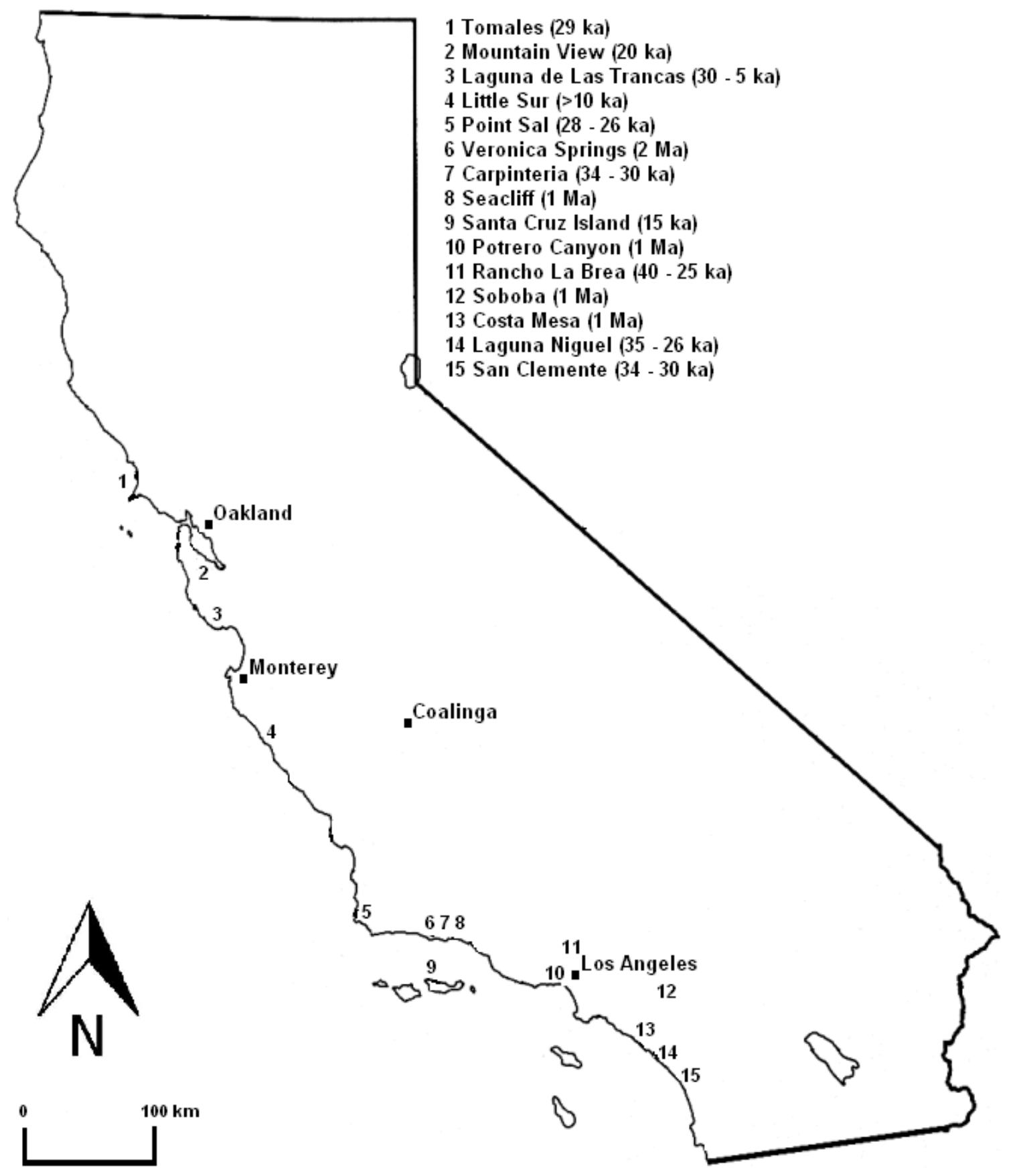

FIG. 20. Pleistocene fossil floras. Locations of floras based on Chaney and Mason 1930, 1933; Potbury 1932; Mason 1934; Langenheim and Durham 1963; Axelrod 1966, 1983; Helley et al. 1972; Adam et al. 1979; Axelrod and Hill 1988; Axelrod and Govean 1996. 
Because the coastal region was an area of active uplift during the Pleistocene, many fossil floras were likely deposited on sites that were formerly nearer sea level and, in some cases, may have covered lowland areas as exemplified by the Mountain View flora in the southwestern corner of the San Francisco Bay Area (Helley et al. 1972). Widespread distribution of closed-cone woodlands during the Pleistocene may have prevented incursions by chaparral taxa. Many coastal Pleistocene floras have limited representation of chaparral taxa, indicating source populations of chaparral taxa were from relatively distant slopes (Axelrod 1966, 1983).

The Soboba flora $(\sim 1 \mathrm{Ma})$ in southern California, contemporaneous with the coastal Seacliff, Potrero Canyon, and Costa Mesa paleofloras ( 246, 90, and $148 \mathrm{~km}$ from the Soboba flora, respectively) indicates drier conditions inland due to the occurrence of chaparral taxa (Ceanothus, Cercocarpus, Garrya, Mahonia, Prunus). However, big cone spruce (Pseudotsuga macrocarpa), Coulter's, sugar, and ponderosa pines (Pinus coulteri, P. lambertiana, P. ponderosa) and white fir (Abies concolor) that now occur at higher elevations were also present in the Soboba flora and indicate that the Pleistocene environment at the time of deposition was more moist than present despite its inland position. Precipitation was $38-50 \mathrm{~cm}$ greater than present, $20 \%$ of which occurred as summer rainfall; the mean annual temperature was $4-5.5^{\circ} \mathrm{C}$ lower than present and there was light winter snowfall in the lowlands (Axelrod 1966, 1983). 
Holocene $(20,000 \mathrm{ka})$. The last glacial maximum $\sim 18 \mathrm{ka}$ was followed by deglaciation $\sim 12 \mathrm{ka}$ and thermal maximum $\sim 6$ ka when temperatures were $1.4-$ $2.1^{\circ} \mathrm{C}$ warmer than present (Thompson et al. 1993). Rising temperatures and aridity resulted in range contraction and thinning of coastal conifer woodlands, local delineation of vegetation by the segregation of mesic and xeric taxa into chaparral and coastal sage scrub, and the expansion of those species better adapted to an increasingly extreme environment (Axelrod 1958, 1981, 1983, 1989).

As previously mentioned, chaparral taxa did not form climax communities in the Tertiary but, rather, were seral to and understory associates of woodland taxa; contemporary zonal stands of chaparral are a Quaternary phenomenon (Axelrod 1989). In addition, although chaparral taxa were solidly emplaced in southern California by the middle Miocene, they were most diverse and wideranging by the Pliocene. Interestingly, this diversity did not seem to include chamise, which is so prevalent today (Axelrod 1958, 1989).

The origin of chamise is unknown. It has not been included as an important associate of the Madro-Tertiary Geoflora (Axelrod 1958) although its extreme isolation from close ancestors, North American desert shrub Chamaebatiaria millefolium and deciduous Asian tree, Sorbaria (Potter et al. 2007; Vamosi and Dickinson 2006), suggests a Tertiary origin (Raven 1973; Axelrod 1989; Axelrod and Raven 1985). This implies the abundance of chamise 
has been negligible until fairly recently, and certainly not sufficiently prevalent to create the vast stretches of monotypic stands that it does today.

Thus, the present dominance of chamise in the central Coast Ranges may be a relatively recent artifact of climate change. Regional uplift and the onset of the Mediterranean climate regime in California resulted in higher summer temperatures and less precipitation in the desert regions where chaparral taxa were prevalent during the Tertiary. In turn, chaparral taxa were extirpated from the rain shadows of uplifted ranges bordering desert provinces and restricted to regions of the southwest where summer rain is still prevalent or to comparatively mesic locations in California and Baja California (Axelrod 1973, 1989). Perhaps, the formation of present associations of chaparral also occurred as range contraction of chaparral taxa became more pronounced. During dry periods of the Quaternary, the comparatively mesic maritime chaparral in the northern Salinas Valley was restricted to coastal locations (the Monterey Bay area and Watsonville Basin). In contrast, the range of chamise may have expanded into arid locations.

Chamise tends to form climax communities where conditions are particularly dry such as ridge tops and steep, south-facing slopes but forms more diverse associations with other woody taxa where conditions are mesic. Similar to other chaparral associates, chamise may have been seral to woodlands in California, particularly where conditions were moister. As the Coast Range topography changed, chamise may have been one of few species that could 
successfully occupy steep, edaphically dry slopes. Increasingly arid conditions and anthropogenic ignitions introduced after $\sim 13 \mathrm{ka}$ (Erlandson et al. 2008) may have amplified fire frequencies and resulted in further changes to vegetation structure that favored expansion of chamise (Axelrod 1973, 1989).

The range expansion of chamise may have contributed conditions that were favorable for the rapid radiation of diverse annual taxa in the chaparral ecosystem. This is consistent with the suggestions that many annual species are relatively recent additions to Quaternary floras (Axelrod 1973, 1989; Raven 1973) and recent radiations among annuals most likely occurred in recently formed communities such as chaparral (Stebbins and Major 1965; Reveal 1978).

\section{Endemism and Biogeography of Eriogonum nortonii}

The California Floristic Province has a rich diversity of endemic taxa, many of which have particularly narrow distributions; over $60 \%$ of endemics in California have ranges $<10,000 \mathrm{~km}^{2}$ (Thorne et al. 2009). Restricted distributions have generally been attributed to factors associated with ecological inferiority that inhibit exploitation of diverse habitats (Gaston and Lawton 1990; Hanski et al. 1993; Walck et al. 1999) including low reproductive investment (i.e. low pollen-ovule ratios), production of fewer seed (Walck et al. 1999; Lavergne et al. 2004), small features (Lavergne et al. 2004), small population size (Gaston and Lawton 1990), and poor dispersability (Hanski et al. 1993; Edwards and Westoby 1996; Lloyd et al. 2003). 
In some cases the distributions of narrowly endemic taxa may be due to historical and landscape processes that have resulted in both paleoendemic and neoendemic taxa with restricted distributions. Paleoendemism is the result of range contraction due to climate change. The expanding cold and aridity since the early Tertiary that contracted the ranges of extant paleoendemics also eliminated or contracted the ranges of close relatives to extents where their distributions no longer overlap. Thus, paleoendemics may not share close ties with contemporary taxa, or nearest relatives may occur in geographically distant regions. The long fossil histories of paleoendemics also attest to formerly widespread distributions and associations with closely related species (Stebbins and Major 1965; Raven and Axelrod 1978). For example, fossil data of Lyonothamnus accounts for four species, some with overlapping Tertiary ranges that extended from southern California to northern Oregon and central Nevada (Erwin and Schorn 2000). Today, Lyonothamnus floribundus forms a monotypic genus with 2 subspecies and natural populations are restricted to the Channel Islands (Wilken 1993).

Neoendemics may also have restricted distributions resulting from the same climate changes that led to range contraction of paleoendemics, but represent the opposite end of the evolutionary spectrum. By virtue of their youth, neoendemics have generally never been widespread nor accrued the time to build a fossil history, but may share close genetic and geographic ties with a number of other taxa (Stebbins and Major 1965; Raven and Axelrod 1978). 
Studies comparing narrowly distributed and widespread congeneric pairs occurring under similar ecological conditions did not find physiological (Lavergne et al. 2004) or morphological differences (Lesica et al. 2006). In such cases, labels of ecological inferiority fail to explain the local abundance of narrow endemics compared to their widespread congeners. Even where ecological inferiority and its associate factors appear to be a cogent explanation for the cause of restricted distributions, this may merely reflect a present physiological or morphological state that maintains endemism, but does not address the evolutionary and ecological history of the species.

The central Coast Ranges, chiefly parts of San Benito and Monterey counties, are rich in endemic species (Stebbins and Major 1965; Thorne et al. 2009) and of recent origin (Christensen 1965; Page et al. 1998; Ducea et al. 2003). It is thought that geological sites of recent origin are hotspots for plant taxa that have recently speciated, particularly where new geologies occur in regions with young climate regimes and recently formed vegetation associations.

Eriogonum has numerous widespread species as well as many narrow endemics. Eriogonums that are taxonomically separated by minor morphological differences and have relatively restricted distributions suggest a youthful age (Stebbins and Major 1965). Of the eight subgenera in Eriogonum, Oregonium, comprised of all annuals, is considered one of the youngest as most members, including E. nortonii, occur in chaparral in the Coast Ranges (Reveal 1969a, 1978). 
Eriogonum nortonii has a narrow, disjunct distribution. This, in addition to factors associated with neoendemism, suggest a Pliocene or later origin, while its distribution pattern may represent habitat fragmentation or range expansion via the mechanisms of vicariance, long distance dispersal, or habitat change. A vicariant perspective suggests past geomorphological changes in the northern Salinas Valley region have altered a pre-existing Miocene distribution of $E$. nortonii. The Salinas Valley has most likely been a major structural feature since the Miocene (Snetsinger 1962; Tinsley 1975) that has been extended by two periods of slip (Miocene and early Pleistocene) on the Rinconada Fault (Rosenberg and Clark 2009). If populations of E. nortonii had been present on both sides of the Salinas Valley prior to Miocene slip, its distribution would have already been disjunct. Occupation of the Salinas Valley basin from the Miocene to present is not expected given the presence of Tertiary inland seas followed by the advancement of woodland taxa as valley habitat became available. Subsequent fault movement would have resulted in range expansion and, perhaps, greater habitat fragmentation, by rafting populations present on the west side of the valley towards the northwest.

Palynological studies in the southern California borderlands suggest a strong abundance of Eriogonum at the start of the Pliocene, the most arid period of the Tertiary (Ballog and Malloy 1981). Certainly, if Eriogonum was present in Wyoming and Idaho in the middle Miocene, as suggested by Leopold and Denton (1987), it was likely also present in California where inland seas were 
absent. Thus, the Pliocene spike in pollen does not suggest a period of origin of Eriogonum in southern California but, rather, indicates extant taxa were expanding in response to increasing aridity to the extent that their numbers were significant enough to contribute to the microflora.

Erdtman (1964) suggested apocratic pollen, an Eriogonum characteristic, is common of opportunistic taxa of arid regions. Apocratic species are generally poor competitors that exploit available habitat during dry conditions or periods of climatic instability where open ground is available for colonization. If true, $E$. nortonii may not have been present in the northern Salinas Valley region until the Holocene, or it may have had a range even more restricted than present and has only recently expanded as habitat has become available.

Furthermore, the likelihood that Miocene populations of E. nortonii were present on the west side of the Salinas Valley, much less most of the Coast Ranges, is diminished by the transgression of Tertiary marine waters over much of the lower elevations in the Sierra de Salinas and Santa Lucia Ranges, including where E. nortonii populations presently occur. Where submergence was intermittent, colonizable habitat would have been intermittent as well and hardwood deciduous forests, oak-laurel woodlands, or closed-cone pine woodlands would have dominated sites that were consistently available during the Tertiary.

By the late Pliocene - early Pleistocene, new habitat was made increasingly available for colonization as marine waters receded and uplift of the 
Coast Ranges ensued. However, due to increased precipitation, much of the landmass was likely colonized by the expansion of woodland communities at the expense of shrublands (Potbury 1932; Dorf 1933; Chaney and Mason 1933; Axelrod 1981, 1983). For range expansion or further habitat fragmentation of $E$. nortonii to have transpired during the Pleistocene, E. nortonii populations would have had to have been present on land west of the Salinas Valley prior to the second period of slip along the Rinconada Fault during the early Pleistocene.

However, colonization by diminutive annuals such as $E$. nortonii, particularly in mesic sites along the coast, would have been severely constrained by advancing closed-cone coniferous woodland that had more prolific ranges during the Pleistocene. In drier areas, oak and oak-laurel woodlands would have been more extensive (Stebbins and Major 1965; Axelrod 1981). Edaphically extreme sites of exposed rock outcrops, resistant to incursions by woodland taxa, as are found around Pinnacles National Monument, may have been refuges for small annuals and for the chaparral habitat in which they are found. As Pleistocene uplift proceeded, erosion rates would have increased to the extent that basement rock and sedimentary rock would have been further exposed, creating more sites for colonization by small annuals such as $E$. nortonii. The predominance of woodlands and the lack of available open habitat during the Pleistocene suggest E. nortonii did not have a Pleistocene distribution similar to its present distribution. 
In contrast, chaparral expanded to the coastal strip in response to increasing aridity, warmer temperatures (Axelrod 1966) and restriction of oak woodlands, mixed evergreen, and redwood forests during the Holocene. As such, potential habitat for small annuals to colonize also expanded (Axelrod 1981), which may have increased the likelihood that $E$. nortonii expanded to the western half of the Salinas Valley at this time as well.

Further support for a Holocene range expansion of E. nortonii relies on assertions that divergence of annual forms of Eriogonum may have most recently occurred during the Quaternary (Shields and Reveal 1988). Annuals, having smaller effective population sizes and shorter life cycles, are more prone to selection under extreme, unstable conditions (Stebbins 1947, 1952; Axelrod 1958, 1972; Raven 1964, 1973; Raven and Axelrod 1978; Linder and Hardy 2004). Even though the Pleistocene climate was generally cooler than present, and fluctuated between glacial and interglacial periods, coastal regions were not subject to the same extreme climatic changes that occurred in alpine regions (Stebbins and Major 1965). It is likely that those unstable conditions were more prevalent at the start of the Holocene, particularly $\sim 8-4$ ka (Thompson et al. 1993).

In summary, the geologic and climatic history of the northern Salinas Valley region indicates that the present distribution of $E$. nortonii in the Gabilan, Sierra de Salinas, and Santa Lucia Ranges is not a result of vicariance, but of recent expansion spurred by Holocene aridity, subsequent expansion of the 
chaparral habitat, and long distance dispersal, which makes recent divergence between populations on opposite sides of the Salinas Valley less likely. 


\section{LITERATURE CITED}

Adam, D. P., R. Byrne, and E. Luthers. 1979. A late Pleistocene and Holocene pollen record from Laguna de Las Trancas, northern coastal Santa Cruz County, California. USGS Open File Report 79-545.

Antweb. 2011. California Academy of Sciences. Website http://www.antweb.org/ [accessed 05 August 2011].

Avery, M. L. and C. van Ripper III. 1989. Seasonal changes in bird communities of the chaparral and blue oak woodlands in central California. The Condor 91(2):288-295.

Axelrod, D. I. 1934. A Pliocene flora from the Eden beds. American Museum Novitates 729:1-4.

1937. A Pliocene flora from the Mount Eden beds, southern California. Contributions to Palaeontology, Carnegie Institute of Washington Publication 476:125-183.

1939. A Miocene flora from the western border of the Mohave Desert. Contributions to Palaeontology, Carnegie Institute of Washington Publication 516.

. 1940. The Mint Canyon flora of southern California: a preliminary statement. American Journal of Science 238(8):577-585.

. 1944a. The Blackhawk Ranch flora. Contributions to Palaeontology, Carnegie Institute of Washington Publication 590:91-100.

. 1944b. The Mulholland flora. Contributions to Palaeontology, Carnegie Institute of Washington Publication 590:103-145.

.1944c. The Oakdale flora. Contributions to Palaeontology, Carnegie Institute of Washington Publication 590:147-165.

. 1950. The evolution of desert vegetation in western North America. Contributions to Palaeontology, Carnegie Institute of Washington Publication 590:215-306.

1958. Evolution of the Madro-Tertiary geoflora. Botanical Review 24(7):433-509. 
. 1966. The Pleistocene Soboba flora of Southern California. University of California Publications in Geological Sciences 60:1-79.

. 1972. Edaphic aridity as a factor in angiosperm evolution. The American Naturalist 106(949):311-320.

. 1973. History of the Mediterranean ecosystem in California. Pp. 225-277 in F. di Castri and H. Mooney (eds.), Mediterranean type ecosystems, origin and structure. Springer-Verlag, New York, NY.

. 1980. Contributions to the Neogene paleobotany of central California. University of California Publications in Geological Sciences 121.

. 1981. Holocene climatic changes in relation to vegetation disjunction and speciation. The American Naturalist 117(6):847-870.

1983. New Pleistocene conifer records, coastal California. University of California Publications in Geological Sciences 127:35-108.

. 1989. Age and origin of chaparral. Pp 7-19 in S. C. Keeley (ed.), The California chaparral: paradigms reexamined. Natural History Museum of Los Angeles County, Los Angeles, CA Science Series 34.

. 2000. A Miocene (10-12 Ma) evergreen laurel-oak forest from Carmel Valley, California. University of California Publications in Geological Sciences 145.

and F. Govean. 1996. An early Pleistocene closed-cone forest at Costa Mesa, southern California. International Journal of Plant Sciences 157(3):323-329.

and T. G. Hill. 1988. Pinus $\times$ Critchfieldii, a late Pleistocene hybrid pine from coastal southern California. American Journal of Botany 75(4):558569.

and P. H. Raven. 1985. Origins of the Cordilleran flora. Journal of Biogeography 12(1):2147.

Baldwin, T. A. 1963. Landforms of the Salinas Valley, California in Guidebook to the geology of the Salinas Valley and the San Andreas fault. Pacific Section, American Association of Petroleum Geologists and Society for Econonomic Paleontology and Mineralogy, Bakersfield, CA. 
Ballog, R. S. and R. E. Malloy. 1981. Neogene palynology from the southern California continental borderland, site 467, deep sea drilling project leg 63. Initial Reports of the Deep Sea Drilling Project 63:565-576.

Barnett, J. K. and J. A. Crawford. 1994. Pre-laying nutrition of sage grouse hens in Oregon. Journal of Range Management 47(2):114-118.

Barth, A. P., J. L. Wooden, M. Grove, C. E. Jacobson, and J. N. Pedrick. 2003. $\mathrm{U}-\mathrm{Pb}$ zircon geochronology of rocks in the Salinas Valley region of California: a reevaluation of the crustal structure and origin of the Salinian block. Geology 31(6):517-520.

Benedict, L., M. R. Kunzmann, K. Ellison, K. L. Purcell, R. R. Johnson, and L. T. Haight. 2011. California towhee (Melozone crissalis) in A. Poole (ed.), The birds of North America online. Cornell Lab of Ornithology, Ithaca, NY. Website http://bna.birds.cornell.edu/bna/species/632 [accessed 10 September 2011].

Benkman, C. W. and H. R. Pulliam. 1988. The comparative feeding rates of North American sparrows and finches. Ecology 69(4):1195-1199.

Best, T. L. 1986. Dipodomys elephantinus. Mammalian Species 255:1-4.

, R. K. Chesser, D. A. McCullough, and G. D. Baumgardner. 1996. Genic and morphometic variation in kangaroo rats, genus Dipodomys, from coastal California. Journal of Mammalogy 77(3):785-800.

Bowersox, J. R. 2005. Reassessment of extinction patterns of Pliocene molluscs from California and environmental forcing of extinction in the San Joaquin Basin. Palaeogeography, Palaeoclimatology, Palaeoecology 221:55-82.

Bradford, D. F. 1976. Space utilization by rodents in Adenostoma chaparral. Journal of Mammalogy 57(3):576-579.

Bradley, W. G. 1968. Food habits of the antelope ground squirrel in southern Nevada. Journal of Mammalogy 49(1):14-21.

and R. A. Mauer. 1971. Reproduction and food habits of Merriam's kangaroo rat, Dipodomys merriami. Journal of Mammalogy 52(3):497-507.

Brown, J. H. and D. W. Davidson. 1977. Competition between seed-eating rodents and ants in desert ecosystems. Science 196(4292):880-882. 
, O. J. Reichman, and D.W. Davidson. 1979. Granivory in desert ecosystems. Annual Review of Ecology and Systematics 10:201-227.

, J. J. Grover, D. W. Davidson, and G. A. Lieberman. 1975. A preliminary study of seed predation in desert and montane habitats. Ecology 56(4):987-992.

Brown, J. S., B. P. Kotler, R. J. Smith and W. O. Wirtz II. 1988. The effects of owl predation on the foraging behavior of Heteromyid rodents. Oecologia 76:408-415.

Bullock, S. H. 1976. Comparison of the distribution of seed and parent-plant populations. The Southwestern Naturalist 21(3):383-389.

Callaway, R. M. and F. W. Davis. 1993. Vegetation dynamics, fire, and the physical environment in coastal central California. Ecology 74(5):15671578.

Carleton, W. M. 1966. Food habits of two sympatric Colorado Sciurids. Journal of Mammalogy 47(1):91-103.

Carroll, C. R. and D. H. Janzen. 1973. Ecology of foraging by ants. Annual Review of Ecology and Systematics 4:231-257.

CCDA. 2008. California Climate Data Archive, Reno, NV. Website http://www.calclim.dri.edu/ccda/index.html [accessed 05 December 2008].

Chambers, J. C. and J. A. MacMahon. 1994. A day in the life of a seed: movements and fates of seeds and their implications for natural and managed systems. Annual Review of Ecology and Systematics 25:263292.

, J. A. MacMahon, and J. H. Haefner. 1991. Seed entrapment in alpine ecosystems: effects of soil particle size and diaspore morphology. Ecology 72(5):1668-1677.

Chaney, R. W. 1947. Tertiary centers and migration routes. Ecological Monographs 17(2):139-148.

and H. L. Mason. 1930. A Pleistocene flora from Santa Cruz Island, California. Contributions to Palaeontology, Carnegie Institute of Washington Publication 415:1-24. 
and H. L. Mason. 1933. A Pleistocene flora from the asphalt deposits at Carpinteria, California. Contributions to Palaeontology, Carnegie Institute of Washington Publication 415:45-79.

Christensen, M. N. 1965. Late Cenozoic deformation in the central Coast Ranges of California. Geological Society of America Bulletin 76:1105-1124.

CIMIS. 2009. California Irrigation Management Information System, California Department of Water Resources (DWR), Sacramento CA. Website www.cimis.water.ca.gov/cimis [accessed 05 December 2008].

Clark, J. C. and J. D. Reitman. 1973. Oligocene stratigraphy, tectonics, and paleogeography southwest of the San Andreas fault, Santa Cruz Mountains and Gabilan Range, California Coast Ranges. USGS Professional Paper 783.

, E. E. Brabb, and L. I. Rosenberg. 2000. Geologic map of the Spreckels 7.5-minute quadrangle, Monterey County, California. USGS Miscellaneous Field Studies Map MF-2349, scale 1:24,000.

, T. W. Dibblee, H. G. Greene, and O. E. Bowen. 1974. Preliminary geologic map of the Monterey and Seaside 7.5 minute quadrangles, Monterey County, California with emphasis on active faults. USGS Miscellaneous Field Studies Map, MF-577, scale 1:24,000.

Coates-Estrada, R. and A. Estrada. 1988. Frugivory and seed dispersal in Cymbopetalum baillonii (Annonaceae) at Los Tuxtlas, Mexico. Journal of Tropical Ecology 4:157-172.

Collins, P. W. 1999. Rufous-crowned sparrow (Aimophila ruficeps) in A. Poole (ed.), The birds of North America online. Cornell Lab of Ornithology, Ithaca, NY. Website http://bna.birds.cornell.edu/bna/species/472 [accessed 10 September 2011].

Compton, R. R. 1966. Analyses of Plio-Pleistocene deformation and stresses in northern Santa Lucia Range, California. Geological Society of America Bulletin 77:1361-1380.

Condit, C. 1938. The San Pablo Flora of west central California: Miocene and Pliocene floras of western North America. Contributions to Palaeontology, Carnegie Institute of Washington Publication 476:217-268. 
Crist, T. O. and J. A. MacMahon. 1992. Harvester ant foraging and shrub-steppe seeds: interactions of seed resources and seed use. Ecology 73(5):17681779.

Davidson, D. W. 1977a. Species diversity and community organization in desert seed-eating ants. Ecology 58(4):711-724.

. 1977b. Foraging ecology and community organization in desert seedeating ants. Ecology 58(4):725-737.

, J. H. Brown, and R. S. Inouye. 1980. Competition and the structure of granivore communities. Bioscience 30(4):233-238.

, D. A. Samson, and R. S. Inouye. 1985. Granivory in the Chihuahuan Desert: interactions within and between trophic levels. Ecology 66(2):486502.

Davies, K. W. and R. L. Sheley. 2007. Influence of neighboring vegetation height on seed dispersal: implications for invasive plant management. Weed Science 55:626-630.

Davis, J., W. D. Koenig, and P. Williams. 1980. Birds of Hastings Reservation, Monterey County, California. Western Birds 11:113-128.

Dibblee, T. W., Jr. 1975. Geologic map of the Hollister quadrangle, California. USGS Open File Maps 75-394, scale 1:62,500.

. 1976. The Rinconada and related faults in the southern Coast Ranges, California and their tectonic significance. USGS Professional Paper 981.

Dickinson, W. R. 1996. Kinematics of transrotational tectonism in the California Transverse Ranges and its contribution to cumulative slip along the San Andreas transform fault system. Geological Society of America Special Paper 305.

. 1997. Tectonic implications of Cenozoic volcanism in coastal California. Geological Society of America Bulletin 109(8):936-954.

, M. Ducea, L. I. Rosenberg, H. G. Greene, S. A. Graham, J. C. Clark, G. E. Weber, S. Kidder, W. G. Ernst, and E. E. Brabb. 2005. Net dextral slip, Neogene San Gregorio-Hosgri fault zone, coastal California: geologic evidence and tectonic implications. Geological Society of America Special Paper 391. 
and B. P. Wernicke. 1997. Reconciliation of San Andreas slip discrepancy by a combination of interior Basin and Range extension and transrotation near the coast. Geology 25:663-665.

Doerr, T. B. and F. S. Guthery. 1983. Food selection by lesser prairie chickens in northwest Texas. The Southwestern Naturalist 28(3):381-383.

Dohrenwend, J. C. 1975. Plio-Pleistocene geology of the central Salinas Valley and adjacent uplands, Monterey County, California. Ph.D. dissertation. Stanford University, Stanford, CA.

1979. Provenance and paleodrainage of the northern part of the Paso Robles Formation, Monterey County, California. Pp. 77-82 in S. Graham (ed.), Tertiary and Quaternary geology of the Salinas Valley and Santa Lucia Range, Monterey County, California, Pacific coast paleogeography field guide 4. Pacific Section of the Society for Economical Paleontologists and Mineralogists, Bakersfield, CA.

Dorf, E. 1933. Pliocene floras of California: studies of the Pliocene paleobotany. Contributions to Palaeontology, Carnegie Institute of Washington Publication 412.

Ducea, M., M. A. House, and S. Kidder. 2003. Late Cenozoic denudation and uplift rates in the Santa Lucia Mountains, California. Geology 31(2):139142.

Dupré, W. R. 1990. Maps showing geology and liquefaction susceptibility of Quaternary deposits in the Monterey, Seaside, Spreckels, and Carmel Valley quadrangles, Monterey County, California. USGS Miscellaneous Field Studies Map MF 2096, scale 1:24,000.

Edwards, W. and M. Westoby. 1996. Reserve mass and dispersal investment in relation to geographic range of plant species: phylogenetically independent contrasts. Journal of Biogeography 23(3):329-338.

Eisenberg, J. F. 1963. The intraspecific social behavior of some Crecitine rodents of the genus Peromyscus. American Midland Naturalist 69(1):240-246.

Ellner, S. and A. Shmida. 1981. Why are adaptations for long-range seed dispersal rare in desert plants? Oecologia 51(1):133-144.

Emmons, G. 2011. A checklist of birds of Pinnacles National Monument. Western National Parks Association, Tucson, AZ. 
Erdtman, G. 1964. Palynology. Pp. 23-54 in Turrill (ed.), Vistas in botany, recent researches in taxonomy, vol. 4 in R. C. Rollins and G. Taylor (eds.), International series of monographs on pure and applied biology, division: botany. The MacMillan Company, NY.

Erlandson, J. M., M. L. Moss, and M. Des Lauriers. 2008. Life on the edge: early maritime cultures of the Pacific coast of North America. Quaternary Science Reviews 27:2232-2245.

Erwin, D. M. and H. E. Schorn. 2000. Revision of Lyonothamnus A. Gray (Rosaceae) from the Neogene of western North America. International Journal of Plant Sciences 161(1):179-193.

ESRI. 2006. ARCMAP 9.2. Environmental Systems Research Institute. Redlands, CA.

Fellers, G. M. 1994. Species diversity, selectivity, and habitat associations of small mammals from coastal California. The Southwestern Naturalist 39(2):128-136.

and A. Fesnock. 2006. Checklist of mammals of Pinnacles National Monument. Website http://www.nps.gov/pinn/naturescience [accessed 14 March 2008].

Fewell, J. H and J. F. Harrison. 1991. Flexible seed selection by individual harvester ants, Pogonomyrmex occidentalis. Behavioral Ecology and Sociobiology 28(6):377-384.

Folgarait, P. J. and O. E. Sala. 2002. Granivory rates by rodents, insects, and birds at different microsites in the Patagonian steppe. Ecography 25(4):417-427.

Gaston, K. J. and J. H. Lawton. 1990. Effects of scale and habitat on the relationship between regional distribution and local abundance. Oikos 58(3):329-335.

Glading, B., H. H. Biswell, and C. F. Smith. 1940. Studies on the food of the California quail in 1937. Journal of Wildlife Management 4(2):128-144.

Gordon, D. M. 1993. The spatial scale of seed collection by harvester ants. Oecologia 95(4):479-487.

Graham, A. 1999. Late Cretaceous and Cenozoic history of North American vegetation. Oxford University Press, Oxford, UK 
Graham, S. A., R. G. Stanley, J. V. Bent, and J. B. Carter. 1989. Oligocene and Miocene paleogeography of central California and displacement along the San Andreas fault. Geological Society of America Bulletin 101:711-730.

Greene, E. L. 1892. New or noteworthy species: Eriogonum nortonii. Pittonia. 2(2):165.

Greenlaw, J. S. 1977. Taxonomic distribution, origin, and evolution of bilateral scratching in ground-feeding birds. The Condor 79(4):426-439. 1996. Spotted towhee (Pipilo maculatus) in A. Poole (ed.), The birds of North America online. Cornell Lab of Ornithology, Ithaca, NY. Website http://bna.birds.cornell.edu/bna/species/263 [accessed 10 September 2011].

Gribi, E. A., Jr. 1967. Ancient shorelines of the Gabilan uplift, in Gabilan Range and adjacent San Andreas fault. Pacific Section, Am. Assoc. Petroleum Geologists and Society of Economic Paleontologists and Mineralogists, Bakersfield, CA.

Griffin, J. T. 1995. Flora of Hastings Reservation, Carmel Valley, California. http://www.hastingsreserve.org/plants [accessed 14 March 2008].

Gullion, G. W. 1960. The ecology of Gambel's quail in Nevada and the arid southwest. Ecology 41(3):518-536.

Hall, C. A. 2002. Nearshore marine paleoclimatic regions, increasing zoogeographic provinciality, molluscan extinctions, and paleoshorelines, California: late Oligocene (27 Ma) to Late Pliocene (2.5 Ma). Geological Society of America Special Paper 357.

Hallett, J. G. 1982. Habitat selection and the community matrix of a desert smallmammal fauna. Ecology 63(5):1400-1410.

Hanski, I., J. Kouki, and A. Halkka. 1993. Three explanations of the positive relationship between distribution and abundance of species. Pp. 108-116 in R. E. Ricklefs and D. Schluter (eds.), Species diversity in ecological communities. University of Chicago Press, Chicago, IL.

Hawbecker, A. C. 1940. The burrowing and feeding habits of Dipodomys venustus. Journal of Mammalogy 21(4):388-396. 
Hay, M. E. and P. J. Fuller. 1981. Seed escape from Heteromyid rodents: the importance of microhabitat and seed preference. Ecology 62(5):13951399.

Helley, E. J., D. P. Adam, and D. B. Burke. 1972. Late Quaternary stratigraphic and paleoecological investigations in the San Francisco Bay Area. Pp. 1929 in A. A. Frizzel (ed.), Progress report on the USGS Quaternary studies in the San Francisco Bay area. Guidebook for Friends of the Pleistocene, USGS, Menlo Park, CA.

Herrera, C. M. 1984. Adaptation to frugivory of Mediterranean avian seed dispersers. Ecology 65(2):609-617.

Heske, E. J. 1990. Calhoun small mammals trapline. Website http://www.hastingsreserve.org/Mammals [accessed 10 September 2011].

, D. L. Rosenblatt, and D. W. Sugg. 1997. Population dynamics of small mammals in an oak woodland-grassland-chaparral habitat mosaic. The Southwestern Naturalist 42(1):1-12.

Hickman, J. C. 1993. Eriogonum. Pp. 860-883 in J. C. Hickman (ed.), The Jepson manual: higher plants of California. University of California Press, Berkeley, CA.

Higgins, S. I., R. Nathan, and M. L. Cain. 2003. Are long-distance dispersal events in plants usually caused by nonstandard means of dispersal? Ecology 84(8):1945-1956.

Holbrook, K. M., and B. A. Loiselle. 2007. Using toucan-generated seed shadows to estimate seed dispersal in Amazonia Ecuador. Pp. 300-321 in A. J. Dennis, E. W. Schupp, R. Green, and D. W. Westcott (eds.), Seed dispersal: theory and its applications in a changing world. CABI Publishing, Wallingford, Oxfordshire, UK.

Hölldobler, B. and E. O. Wilson. 1990. The Ants. The Belknap Press of Harvard University Press, Cambridge, MA.

Howard, A. D. 1973. Modified contour-generalization procedure as applied to the Santa Lucia Range, California. Geological Society of America Bulletin 84:3415-3428.

Howe, H. F and J. Smallwood.1982. Ecology of seed dispersal. Annual Review of Ecology and Systematics 13:201-28. 
Hrabar, H. and M. Perrin. 2002. The effect of bill structure on seed selection by granivorous birds. African Zoology 37(1):67-80.

Huffman, O. F. 1972. Lateral displacement of Upper Miocene rocks and the Neogene history of offset along the San Andreas fault in central California. Geological Society of America Bulletin 83:2913-2946.

Hughes, L., M. Dunlop, K. French, M. R. Leishman, B. Rice, L. Rodgerson, and M. Westoby. 1994. Predicting dispersal spectra: a minimal set of hypotheses based on plant attributes. Journal of Ecology 82(4):933-950.

Jones, R. E. 1964. Habitat used by lesser prairie chickens for feeding related to seasonal behavior of plants in Beaver County, Oklahoma. The Southwestern Naturalist 9(3):111-117.

Jordano, P. 1988. Diet, fruit choice, and variation in body condition of frugivorous warblers in Mediterranean scrubland. Ardea 76(2):193-209.

Kelrick, M. I., J. A. MacMahon, R. R. Parmenter, and D. V. Sisson. 1986. Native seed preferences of shrub-steppe rodents, birds and ants: the relationships of seed attributes and seed use. Oecologia 68(3):327-337.

Kelt, D. A. 1988. Dipodomys heermanni. Mammalian Species 323:1-7.

Kilkenny, J. E. 1948. Geology and exploration for oil in Salinas Valley, California. AAPG Bulletin 32(12):2254-2268.

Krefting, L. W. and E. I. Roe. 1949. The role of some birds and mammals in seed germination. Ecological Monographs 19(3):269-286.

Kuparinen, A., G. Katul, R. Nathan, and F. M. Schurr. 2009. Increases in air temperature can promote wind-driven dispersal and spread of plants. Proceedings of the Royal Society of Biological Sciences 276:3081-3087.

Laakkonen, J. 2003. Effect of arboreal activity on species composition and abundance estimates in a chaparral habitat in southern California. American Midland Naturalist 150(2):348-351.

Lambert, F. R. 1989. Pigeons as seed predators and dispersers of figs in a Malaysian lowland forest. Ibis 131:521-527.

Langenheim, J. H. and J. W. Durham. 1963. Quaternary closed-cone pine forest from travertine near Little Sur, California. Madroño 17:33-51. 
Lavergne, S., J. D. Thompson, E. Garnier, and M. Debussche. 2004. The biology and ecology of narrow endemic and widespread plants: a comparative study of trait variation in 20 congeneric pairs. Oikos 107:505-518.

Lemen, C. A. and M. L. Rosenzweig. 1978. Microhabitat selection in two species of heteromyid rodents. Oecologia 33(2):127-135.

Lengyel, S., A. D. Gove, A. M. Latimer, J. D. Majer, and R. R. Dunn. 2009. Ants sow the seeds of global diversification in flowering plants. PloS ONE 4(5):e5480.

Leopold, A. S. and M. A. McCabe. 1957. Natural history of the Montezuma quail in Mexico. The Condor 59(1):3-26

Leopold, E. B. and M. F. Denton. 1987. Comparative age of grassland and steppe east and west of the northern Rocky Mountain. Annals of the Missouri Botanical Garden 74(4):841-867.

Lesica, P., R. Yurkewycz, and E. E. Crone. 2006. Rare plants are common where you find them. American Journal of Botany 93(3):454-459.

Levin, S. A., H. C. Muller-Landau, R. Nathan, and J. Chave. 2003. The ecology and evolution of seed dispersal: a theoretical perspective. Annual Review of Ecology, Evolution and Systematics 34:575-604.

Linder, H. P. and C. R. Hardy. 2004. Evolution of the species-rich Cape flora. Philosophical Transactions of the Royal Society: Biological Sciences 359(1450):1623-1632.

Linsdale, J. 1945. Formicidae (ants) at Hastings Reserve: checklist of the insects of Francis Simes Hastings Natural History Reservation. Website http://www.hastingsreserve.org/Invertebrates [accessed 10 September 2011].

Lloyd, K. M. J. B. Wilson, and W. G. Lee. 2003. Correlates of geographic range size in New Zealand Chionochloa (Poaceae) species. Journal of Biogeography 30:1757-1761.

Loiselle, B. A. 1990. Seeds in droppings of tropical fruit-eating birds: importance of considering seed composition. Oecologia 82(4):494-500.

Longland, W. S. and M. V. Price. 1991. Direct observations of owls and Heteromyid rodents: can predation risk explain microhabitat use? Ecology 72(6):2261-2273. 
Lorts, C. M., T. Briggeman, and T. Sang. 2008. Evolution of fruit types and seed dispersal: a phylogenetic and ecological snapshot. Journal of Systematics and Evolution 46(3):396-404.

MacArthur, R. H. and J. W. MacArthur. 1961. On bird species diversity. Ecology 42(3):594-598.

MacKay, W. P. and E. E. MacKay. 1989. Diurnal patterns of Pogonomyrmex harvester ants (Hymenoptera: Formicidae). The Southwestern Naturalist 34(2):213-218.

Mares, M. A. 1993. Desert rodents, seed consumption, and convergence. Bioscience 43(6):372-379. and M. L. Rosenzweig. 1978. Granivory in North and South American deserts: rodents, birds, and ants. Ecology 59(2):235-241.

Martin, J. W. and B. A. Carlson. 1998. Sage sparrow (Amphispiza belli) in A. Poole (ed.), The birds of North America online. Cornell Lab of Ornithology, Ithaca, NY. Website http://bna.birds.cornell.edu/bna/species/326 [accessed 10 September 2011].

Martin, P. S. and J. Gray. 1962. Pollen analysis and the Cenozoic. Science. 137(3524):103-111.

Mason, H. L. 1934. Pleistocene flora of the Tomales Formation: studies of the Pleistocene palaeobotany. Contributions to Palaeontology, Carnegie Institute of Washington Publication 415:81-179.

Matthews, V. 1976. Geology of the Pinnacles Volcanic Formation and the Neenach Volcanic Formation and their bearing on the San Andreas fault problem. Ph.D. dissertation. University of California, Santa Cruz, CA.

M'Closkey, R. T. 1978. Niche separation and assembly in four species of Sonoran Desert rodents. The American Naturalist 112(986):683-694.

McQuarrie, N. and B. P. Wernicke. 2005. An animated tectonic reconstruction of southwestern North America since 36 Ma. Geosphere 1(3):147-172.

Melhop, P. and N. J. Scott. 1983. Temporal patterns of seed use and availability in a guild of desert ants. Ecological Entomology 8:69-85.

Meserve, P. L. 1976. Food relationships of a rodent fauna in a California coastal sage scrub community. Journal of Mammalogy 57(2):300-319. 
. 1977. Three-dimensional home ranges of Cricetid rodents. Journal of Mammalogy 58(4): 549-558.

Meyer, S. E. 2008. Polygonaceae (buckwheat family): Eriogonum Michx. (wild buckwheat, buckbrush). Pp. 499-503 in Bonner, F. T. and R. P. Karrfalt (eds.), The woody plant seed manual. USDA Agricultural Handbook No. 727, Washington, D.C.

Milesi, F. A., J. L. de Casenave, and V. R. Cueto. 2008. Selection of foraging sites by desert granivorous birds: vegetation structure, seed availability, species-specific foraging tactics, and spatial scale. The Auk 125(2):473484.

Mills, J. N. and J. Kummerow. 1989. Herbivores, seed predators, and chaparral succession. Pp 49-55 in S. C. Keeley (ed.), The California chaparral: paradigms reexamined. Natural History Museum of Los Angeles County, Los Angeles, CA Science Series 34.

Minitab. 2006. Minitab Statistical Software v.15. State College, PA.

Murphy, S. R., N. Reid, Z. Yan, and W. N. Venables. 1993. Differential passage time of mistletoe fruits through the gut of honeyeaters and flowerpeckers: effects on seedling establishment. Oecologia 93(2):171-176.

Nathan, R., G. G. Katul, H. S. Horn, S. M. Thomas, R. Oren, R. Avissar, S. W. Pacala, and S. A. Levin. 2002. Mechanisms of long-distance dispersal of seeds by wind. Nature 418:409-413.

Nathan, R., F. M. Schurr, O. Spiegel, O. Steinitz, A. Trakhtenbrot, and A. Tsoar. 2008. Mechanisms of long-distance seed dispersal. Trends in Ecology and Evolution 23(11):638-647.

Nelson, J. F. and R. M. Chew. 1977. Factors affecting seed reserves in the soil of a Mojave Desert ecosystem, Rock Valley, Nye County, Nevada. American Midland Naturalist 97(2):300-320.

Nicholson, C., C. C. Sorlien, T. Atwater, J. C. Crowell, and B. P. Luyendyk. 1994. Microplate capture, rotation of the western Transverse Ranges, and initiation of the San Andreas transform as a low-angle fault system. Geology 22:491-495.

Page, B. P., G. A. Thompson, and R. G. Coleman. 1998. Late Cenozoic tectonics of the central and southern Coast Ranges of California. Geological Society of America Bulletin 110(7);846-876. 
Pirk, G. I and J. L. de Casenave. 2006. Diet and seed removal rates by the harvester ants Pogonomyrmex rastratus and Pogonomyrmex pronotalis in the central Monte Desert, Argentina. Insectes Sociaux 53:119-125.

Potbury, S. S. 1932. A Pleistocene flora from San Bruno, San Mateo County, California: studies of the Pleistocene palaeobotany. Contributions to Palaeontology. Carnegie Institute of Washington Publication 415:25-44.

Potter, D., T. Eriksson, R. C. Evans, S. Oh, J. E. E. Smedmark, D. R. Morgan, M. Kerr, K. R. Robertson, M. Arsenault, T. A. Dickinson, and C. S. Campbell. 2007. Phylogeny and classification of Rosaceae. Plant Systematics and Evolution 266:5-43.

Powell, C. L., J. A. Barron, A. M. Sarna-Wojcicki, J. C. Clark, F. A. Perry, E. E. Brabb, and R. J. Fleck. 2007. Age, stratigraphy, and correlations of the late Neogene Purisima Formation, central California Coast Ranges. USGS Professional Paper 1740.

Powell, R. E. 1993. Balanced palinspastic reconstruction of pre-late Cenozoic paleogeography, southern California: geologic and kinematic constraints on evolution of the San Andreas fault system. Pp. 1-106 in R. E. Powell, R. J. Weldon and J. C. Matti (eds.), The San Andreas fault system: displacement, palinspastic reconstruction, and geologic evolution. Geological Society of America Memoir 178.

Pulliam, H. R. and M. R. Brand. 1975. The production and utilization of seeds in plains grassland of southeastern Arizona. Ecology 56(5):1158-1166.

and G. S. Mills. 1977. The use of space by wintering sparrows. Ecology 58(6):1393-1399.

Raven, P. H. 1964. Catastrophic selection and edaphic endemism. Evolution. 18(2):336-338.

. 1973. Evolution of Mediterranean floras. Pp. 213-224 in F. di Castri and $\mathrm{H}$. Mooney (eds.), Mediterranean type ecosystems, origin and structure. Springer-Verlag, New York, NY.

and D. I. Axelrod. 1978. Origin and relationships of the California flora. University of California Publications in Botany 72.

Reichman, O. J. 1979. Desert granivore foraging and its impact on seed densities and distributions. Ecology 60(6):1085-1092. 
. 1984. Spatial and temporal variation of seed distributions in Sonoran Desert soils. Journal of Biogeography. 11(1):1-11.

and D. Oberstein. 1977. Selection of seed distribution types by

Dipodomys merriami and Perognathus Amplus. Ecology 58(3):636-643.

Renney, K. M. 1972. The Miocene Temblor flora of west central California. M.S. thesis. University of California, Davis CA.

Repasky, R. R. and D. Schluter. 1994. Habitat distributions of wintering sparrows along an elevational gradient: tests of the food, predation and microhabitat structure hypotheses. Journal of Animal Ecology 63(3):569-582.

Reveal, J. L. 1969a. The subgeneric concept in Eriogonum (Polygonaceae). Pp. 229-249 in J. Gunckel (ed.), Current topics in plant science. Academic Press, NY.

. 1969b. A revision of the genus Eriogonum (Polygonaceae). Ph.D. dissertation. Brigham Young University, Provo, UT.

. 1978. Distribution and phylogeny of Eriogonoideae (Polygonaceae). Great Basin Naturalist Memoirs 2:169-190.

. 1981. Eriogonum divaricatum Hook. (Polygonaceae), an intermountain species in Argentina. Great Basin Naturalist 41(1):143-146.

. 2005. Eriogonum nortonii in Editorial Committee (eds.) Flora of North America north of Mexico, vol. 5. New York, NY. Website http://www.efloras.org/florataxon [accessed 25 June 2010].

Ribble, D. O. and F. B. Samson. 1987. Microhabitat associations of small mammals in southeastern Colorado, with special emphasis on Peromyscus (Rodentia). The Southwestern Naturalist 32(3):291-303.

Rich, F. J. and F. L. Pirkle. 1994. Paleoecolgical interpretation of the Trail Ridge Sequence, and related deposits in Georgia and Florida, based on pollen sedimentation and clastic sedimentology. Pp. 287-310 in A. Traverse (ed.), Sedimentation of organic particles. Cambridge University Press, Cambridge, UK.

Rosenberg, L. I. and J. C. Clark. 2009. Map of the Rinconada and Reliz fault zones, Salinas river valley, California. USGS Scientific Investigations Map 3059 . 
Roth, R. R. 1976. Spatial heterogeneity and bird species diversity. Ecology 57(4):773-782.

Ryder, R. T. and A. Thomson. 1989. Tectonically controlled fan delta and submarine fan sedimentation of late Miocene age, southern Temblor Range, California. USGS Professional Paper 1442.

Samson, D. A., T. E. Philippi, and D. W. Davidson. 1992. Granivory and competition as determinants of annual plant diversity in the Chihuahuan Desert. Oikos 65(1):61-80.

Sanchez, A. and K. A. Kron. 2008. Phylogenetics of Polygonaceae with an emphasis on the evolution of Eriogonoideae. Systematic Botany 33(1):8796.

Schupp, E. W. 1993. Quantity, quality and effectiveness of seed dispersal by animals. Vegetatio 107/108:15-29.

Shields, O. and J. L. Reveal. 1988. Sequential evolution of Euphilotes (Lycaenidae: Scolitantidini) on their plant host Eriogonum (Polygonaceae: Eriogonoideae). Biological Journal of the Linnean Society 33(1):51-93.

Sims, J. D. 1993. Chronology of displacement on the San Andreas fault in central California: evidence from reversed positions of exotic rock bodies near Parkfield, California. Pp. 231-256 in R. E. Powell, R. J. Weldon and J. C. Matti (eds.), The San Andreas fault system: displacement, palinspastic reconstruction, and geologic evolution. Geological Society of America Memoir 178.

Smartt, R. A. 1978. A comparison of ecological and morphological overlap in a Peromyscus community. Ecology 59(2):216-220.

Snetsinger, K. G. 1962. Late Tertiary and Quaternary history of the lower Arroyo Seco area, Monterey County, California. M.S. thesis. Stanford University, Stanford, CA.

Srivastava, S. K. 1984. Palynology of the Monterey Formation (Miocene) Phosphatic facies at Lions Head, Santa Maria area, California. Palynology 8:33-49.

Stanley, R. G., D. S. Wilson, and P. A. McCrory. 2000. Locations and ages of middle Tertiary volcanic centers in coastal California. USGS Open File Report 00-154. 
Stebbins, G. L. 1947. Evidence on rates of evolution from the distribution of existing and fossil plant species. Ecological Monographs 17(2):149-158. 1952. Aridity as a stimulus to plant evolution. The American Naturalist 86(826):33-44.

and J. Major. 1965. Endemism and speciation in the California flora. Ecological Monographs 35(1):1-35.

Stokes, S. G.1936. The genus Eriogonum, a preliminary study based on geographical distribution. J. H. Nesbitt Press, San Francisco, CA .

Tackenberg, O. 2003. Modeling long-distance dispersal of plant diaspores by wind. Ecological Monographs 73(2):173-189.

, P. Poschlod, and S. Bonn. 2003. Assessment of wind dispersal in plants. Ecological Monographs 73(2):191-205.

Taraborelli, P. A., M. Dacar, and S. M. Giannoni. 2003. Effect of plant cover on seed removal by rodents in the Monte Desert (Mendoza, Argentina). Austral Ecology 28:651-657.

Tevis, L. 1958. Interrelations between the harvester ant Veromessor pergandei (Mayr) and some desert ephemerals. Ecology 39(4):695-704.

Thompson, K. 1987. Seeds and seed banks. New Phytologist 106(1):23-34.

, S. R. Band, and J. G. Hodgson. 1993. Seed size and shape predict persistence in soil. Functional Ecology 7(2):236-241.

Thompson, R. S., C. Whitlock, P. J. Bartlein, S. P. Harrison, and W. G Spaulding. 1993. Climatic changes in the western United States since 18,000 B.P. Pp. 468-513 in H. E. Wright, Jr., J. E. Jutzback, T. Webb III, W. F. Ruddiman, F. A. Street-Perrott and P. J. Bartlein (eds.), Global climates since the last glacial maximum. University of Minnesota Press, Minneapolis, MN.

Thompson, S. D. 1982a. Microhabitat utilization and foraging behavior of bipedal and quadrupedal Heteromyid rodents. Ecology 63(5):1303-1312.

. 1982b. Structure and species composition of desert Heteromyid rodent species assemblages: effects of a simple habitat manipulation. Ecology 63(5):1313-1321. 
Thorne, J. H., J. H. Viers, J. Price, and D. M. Stoms. 2009. Spatial patterns of endemic plants in California. Natural Areas Journal 29(4):344-366.

Thorngate, N., J. C. Scullen, and J. Olson. 2006. Avian community dynamics in the lower Carmel River watershed, 1992 - 2006. Monterey Peninsula Water Management District, Monterey CA.

Tiffney, B. H. 2004. Vertebrate dispersal of seed plants through time. Annual Review of Ecology, Evolution, and Systematics 35:1-29.

Tinsley, J. C. 1975. Quaternary geology of northern Salinas Valley, Monterey County, California. Ph.D. dissertation. Stanford University, Stanford, CA.

Tomoff, C. S. 1974. Avian species diversity in desert scrub. Ecology 55(2):396403.

Turner, D. L., G. H. Curtis, F. A. Berry, and R. Jack. 1970. Age relationship between the Pinnacles and Parkfield felsites, and felsite clasts of the southern Temblor Range, California: implications for San Andreas fault displacement (abs.). Geological Society of America Abstracts with Programs, 2(2):154.

Twining, H. 1940. Foraging behavior and survival in the Sierra Nevada rosy finch. The Condor 42(1):64-72.

USDA, SSURGO. 2004. Soil survey geographic (SSURGO) database for Pinnacles National Monument, California. Davis, CA. Website http://soildatamart.nrcs.usda.gov [accessed 31 January 2007].

Valone, T. J. and M. R. Schutzenhofer. 2007. Reduced rodent biodiversity stabilizes plant populations. Ecology 88(1):26-31.

Vamosi, J. C. and T. A. Dickinson. 2006. Polyploidy and diversification: a phylogenetic investigation in Rosaceae. International Journal of Plant Sciences 167(2):349-358.

Van der Pijl, L. 1982. Principles of dispersal in higher plants. Springer-Verlag, New York, NY.

Venable, D. L., A. Flores-Martinez, H. C. Muller-Landau, G. Barron-Gafford, and J. X. Becerra. 2008. Seed dispersal of desert annuals. Ecology 89(8):2218-2227. 
Wagner, D. L., H. G. Greene, G. J. Saucedo, and C. L. Pridemore. 2002. Geologic map of the Monterey 30'x60' quadrangle and adjacent areas, California. California Department of Conservation, California Geological Survey, scale 1:100,000.

Walck, J. L., J. M. Baskin, and C. C. Baskin. 1999. Relative competitive abilities and growth characteristics of a narrowly endemic and geographically widespread Solidago species (Asteraceae). American Journal of Botany 86(6):820-828.

Went, F. W., J. Wheeler, and G. C. Wheeler. 1972. Feeding and digestion in some ants (Veromessor and Manica). Bioscience 22(2):82-88.

Whitford, W. G. 1978. Foraging in seed harvester ants Pogonomyrmex ssp. Ecology 59(1):185-189.

Wilken, D. H. 1993. Lyonothamnus. Pp. 961-962 in J. C. Hickman (ed.), The Jepson Manual. University of California Press, Berkeley, CA.

Wilkinson, D. M. 1997. Plant colonization: are wind dispersed seeds really dispersed by birds at larger spatial and temporal scales? Journal of Biogeography 24(1):61-65.

Willson, M. F. 1993. Dispersal mode, seed shadows, and colonization patterns. Vegetatio 107/108:260-280.

Zachos, J., M. Pagani, L. Sloan, E. Thomas, and K. Billups. 2001. Trends, rhythms, and aberrations in global climate $65 \mathrm{Ma}$ to present. Science 292(5517):686-693. 